\title{
UM MÉTODO EXPEDITO DE REPRESENTAÇÃO DA GEOMETRIA DE UMA RODOVIA NA FORMA EM QUE FOI EFETIVAMENTE CONSTRUÍDA
}

\section{CYNTHIA PERPÉTUA LOTTI}

Dissertação apresentada à Escola de Engenharia de São Carlos da Universidade de São Paulo, como parte dos requisitos para obtenção do Título de Mestre em Transportes.

ORIENTADOR: Prof. Dr. João Alexandre Widmer

São Carlos

1997 
Ficha catalográfica preparada pela Seção de Tratamento

da Informaçāo do Serviço de Bíblioteca - EESC-USP

Lotti, Cynthia Perpétua

Um método expedito de representação da

$\mathrm{L} 884 \mathrm{~m}$ geometria de um rodovia na forma em que foi efetivamente construida / Cynthia Perpétua Lotti. - - São Carlos, 1997.

Dissertação (Mestrado). -. Escola de Engenharia de São Carlos-Universidade de São Paulo, 1997.

Área: Transportes

Orientador: Prof. Dr. João Alexandre Widmer

1. Rodovias. 2. Acidentes. 3. Geometria.

4. GPS. 5. SIG. I. Título. 
FOLHA DE APROVACÃO

Candidata: Engenheira CYNTHIA PERPÉTUA LOTTI

Dissertação defendida e aprovada em 04-7-1997

pela Comissão Julgadora:

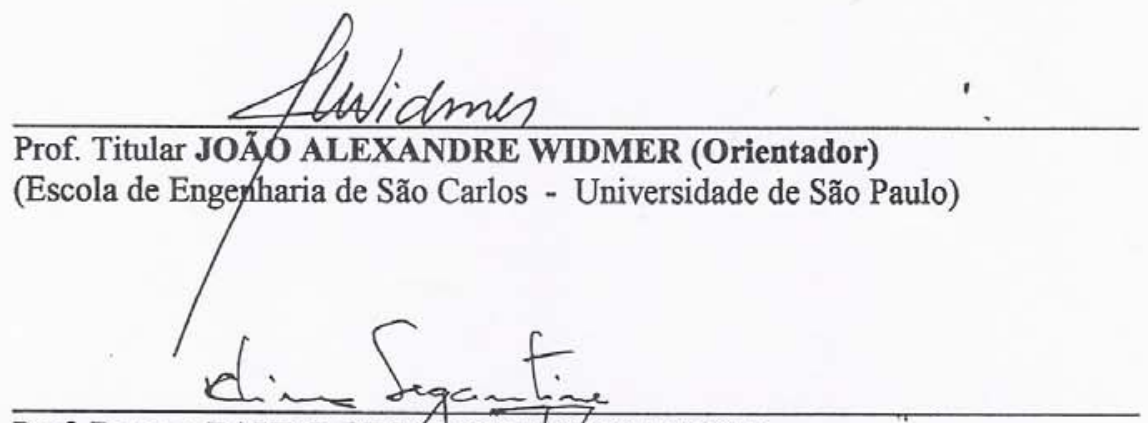

Prof. Doutor PAULO CESAR LIMA SEGANTINE

(Escola de Engenharia de Såo Carlos - Universidade de São Paulo)

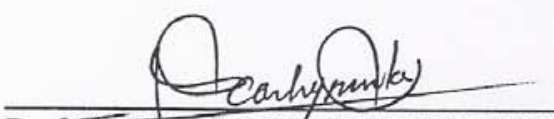

Prof. Doutdr-CARLOS YUKIO SUZUKI

(Escola Politécnica - Universidade de São Paulo)

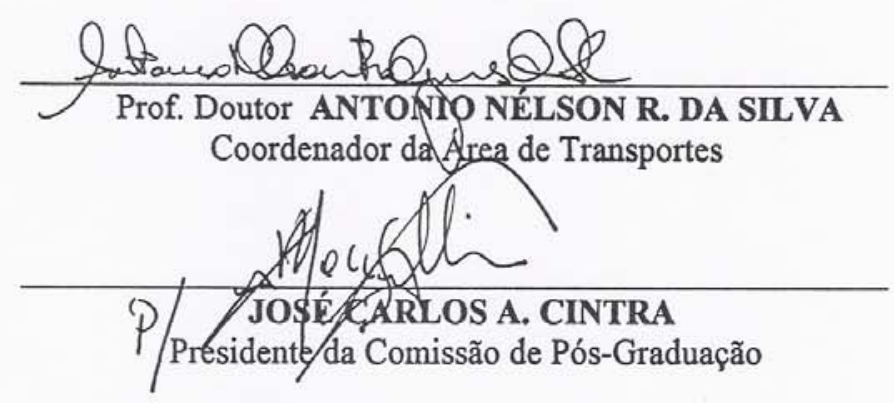


À minha mãe e aos meus irmãos 
"De tudo ficam três coisas:

a certeza de que está sempre começando, a certeza de que era preciso continuar e a certeza de que seria interrompido antes de terminar, fazer da interrupção um caminho novo, fazer da queda um passo de dança, do medo uma escada, do sono uma ponte, da procura um encontro.”

Fernando Sabino

"Viver é a coisa mais rara do mundo.

A maioria das pessoas apenas existe.” 


\section{AGRADECIMENTOS}

Ao Prof. João Alexandre Widmer pela sua orientação e amizade.

Ao CNPQ pela bolsa de estudos concedida.

À Escola Politécnica pelo empréstimo do equipamento da TRIMBLE

À LEICA pelo empréstimo do equipamento GPS

À Polícia Rodoviária, em especial, ao Batalhão de Rio Claro pela sua ajuda durante o levantamento dos dados.

Ao DER pela sua solicitude em atender aos meus pedidos em especial ao Eng. Guedes pela sua colaboração.

Aos professores do Departamento de Transportes, em especial, Prof. Segantine, Prof. Irineu e Prof. Antônio Nelson pela apoio para realização do trabalho Aos professores Edvaldo S. Fonseca Jr. e Ricardo Schaal da Escola Politécnica pela sua colaboração

Ao Professor Segundo C. Lopes da Universidade Federal de São Carlos pelo seu apoio

Aos funcionários do Departamento de Transportes, em especial, ao Gigante, ao Morasco, ao Oliveira e ao Paulinho pela sua ajuda durante o levantamento de dados e ao Vicente, ao Carlos e Heloísa pela sua ajuda durante o desenvolvimento do trabalho.

A todos os meus colegas do Departamento de Transportes, em especial, Attus, Cássio, Renata, Kennedy, Jisela, Marcelo, Sandra Oda, Ricardo, Flávio, Sérgio Demarchi, Sérgio Chisté, Karina, Roberto, Danieli e Luciane pela sua amizade e ajuda durante o levantamento de dados. Aos demais pela amizade e apoio durante estes dois anos.

À minha família pela ajuda durante o levantamento de dados e pelo apoio para realizar este trabalho 


\section{SUMÁRIO}

LISTA DE FIGURAS

LISTA DE TABELAS

LISTA DE ABREVIAÇÕES E SIGLAS

$\mathbf{v}$

LISTA DE SÍMBOLOS

vii

RESUMO

viii

ABSTRACT

ix

1. INTRODUÇ̃̃o

1.1. CONSIDERAÇÕES GERAIS

1.2. JUSTIFICATIVA

4

1.3. OBJETIVO

5

1.4. ORGANIZAÇÃO DO TRABALHO

5 
2.1. A RELAÇÃO ENTRE ACIDENTES E PROJETO GEOMÉTRICO 7

2.1.1. LARGURA DA PISTA 13

2.1.2. ALINHAMENTO HORIZONTAL 16

$\begin{array}{ll}\text { 2.1.3. RAMPAS } & 19\end{array}$

2.1.4. CURVAS VERTICAIS 20

2.1.5. INTERSEÇÕES 21

2.1.6. CONSISTÊNCIA DAS RODOVIAS. 24

2.2 SISTEMAS DE INFORMAÇÕES GEOGRÁFICAS 30

2.3. MÉTODOS DE LEVANTAMENTO DA BASE GEOGRÁFICA 37

2.3.1. MÉTODO CONVENCIONAL 37

2.3.2. FOTOGRAMETRIA 39

2.3.3. SISTEMA INERCIAL 42

2.3.4. GPS 43

2.3.5. VANTAGENS E DESVANTAGENS DOS MÉTODOS 46

3. MÉTODO $\quad 53$

3.1 MÉTODO ESTÁTICO 53

3.2 MÉTODO RÁPIDO ESTÁTICO

3.3 MÉTODO PSEUDOCINEMÁTICO 54

3.4 MÉTODO CINEMÁTICO

3.5 MÉTODO CINEMÁTICO PURO ('ON-THE-FLY’) 55

3.6 MÉTODO SEMI-CINEMÁTICO OU STOP-AND-GO

3.7 FATORES QUE INTERFEREM NA PRECISÃO DO SISTEMA GPS 56

3.7.1 ORIGEM DOS ERROS NO POSICIONAMENTO COM GPS 59

3.7.2 IONOSFERA 60

$\begin{array}{ll}\text { 3.7.3 TROPOSFERA } & 60\end{array}$

3.7.4 MUTICAMINHAMENTO 61

3.7.5 PERDA DE CICLOS 63 
3.7.6 “ANTISPOOFING”(AS)

3.7.7 “SELECTIVE AVAILABILITY”(SA) 68

3.8 MÉTODO UTILIZADO NO LEVANTAMENTO $\mathbf{6 8}$

3.8.1 FORMAS DE RESOLUÇÃO DA AMBIGÜIDADE 70

3.8.2 LEVANTAMENTOS DOS PONTOS UTILIZADOS NA

RESOLUÇÃO DA AMBIGÜIDADE $\quad 74$

3.8.3 INSTALAÇÃO DA ESTAÇÃO MÓVEL

4. ESTUDO DE CASO

4.1.1 LEVANTAMENTO ESTÁTICO

4.1.2 LEVANTAMENTO CINEMÁTICO 80

$\begin{array}{ll}\text { 6.1 CONCLUSÕES } & 108\end{array}$

$\begin{array}{ll}\text { 6.2 SUGESTÕES } & 110\end{array}$

$\begin{array}{lr}\text { ANEXO A } & 114\end{array}$

$\begin{array}{lr}\text { ANEXO B } & 116\end{array}$ 


\section{LISTA DE FIGURAS}

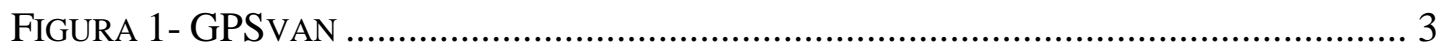

FigURA 2 - TAXA DE ACIDENTES VERSUS CONFLITO DE TRÁFEGO.............................. 23

FIGURA 3 - DIFERENTES VISÕES TRIDIMENSIONAIS COM A SUPERPOSIÇÃO DE CURVAS VERTICAIS E HORIZONTAIS: (A) TANGENTE HORIZONTAL; (B) TANGENTE HORIZONTAL COM SUPERPOSIÇÃO DE UMA CURVA VERTICAL CONVEXA; (C) TANGENTE HORIZONTAL COM SUPERPOSIÇÃO DE UMA CURVA VERTICAL CÔNCAVA; (D) CURVA HORIZONTAL; (E) CURVA HORIZONTAL COM SUPERPOSIÇÃO DE UMA CURVA VERTICAL CONVEXA; (F) CURVA HORIZONTAL COM SUPERPOSIÇÃO DE UMA CURVA VERTICAL CÔNCAVA;

FIGURA 4 - INFLUÊNCIA NA SITUAÇÃO DOS ACIDENTES (ACC) PELA SUPERIMPOSIÇÃO DE CURVAS HORIZONTAIS E VERTICAIS : (A) CÔNCAVA E (B) CONVEXA ................. 28

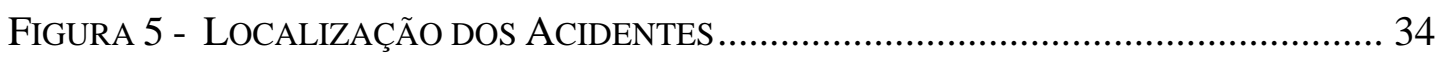

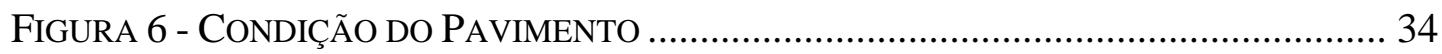

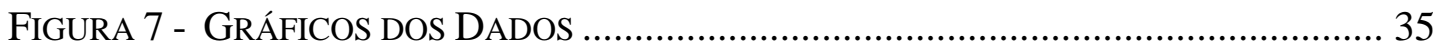

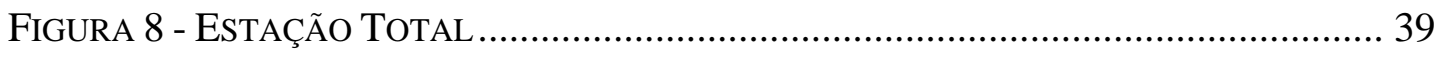

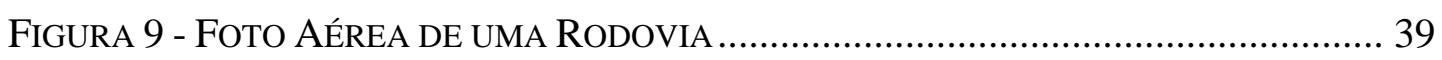

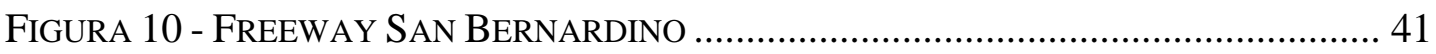

Figura 11 - Mapeamento Obtido Através da Foto AÉrea da Freeway San

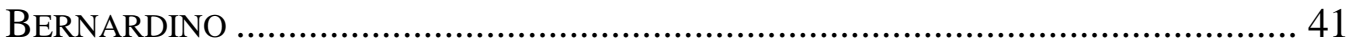

FigURA 12 - Sistema ESQUEMÁtico DE UMA PlatAForma INERCIAL ....................... 42

FIGURA 13 - CONSTELAÇÃO DE SATÉLITES DO GPS................................................... 44

FiguRA 14 - PRINCÍPIO BÁSICO DO POSICIONAMENTO COM GPS ................................ 45

FigURA 15 - PRINCÍPIO DO POSICIONAMENTO COM SATÉLITE ..................................... 46

FIGURA 16- GEOMETRIA DOS SATÉLITES E PDOP ..................................................... 58

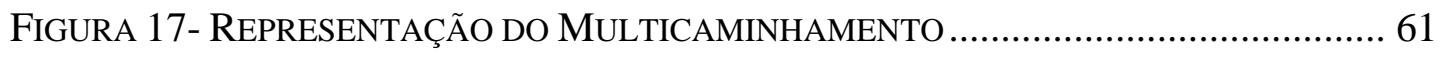

FigURA 18 - REPRESENTAÇÃo GRÁFICA DA PERDA DE CICLO ..................................... 64

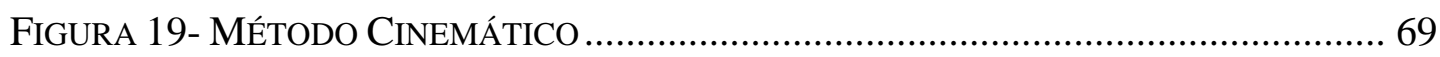


FIgURA 20- MÉtodo DE DETERMinAÇÃo DA AMBIGÜIDADE AtravÉS DO LEVANTAMENTO ESTÁTICO 71

Figura 21- MÉTOdo DE DeterminaÇÃo DA AmbigÜidade AtravÉS DE UMA LinHA

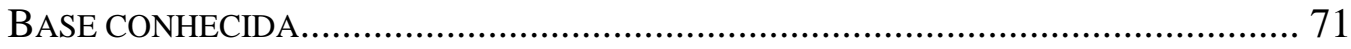

FIGURA 22- TROCA DE ANTENAS - ANTENA SWAP ….................................................... 72

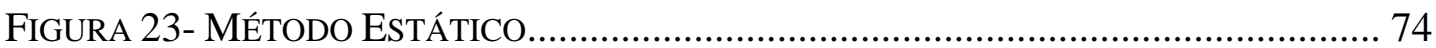

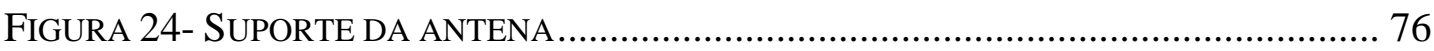

FIGURA 25 - LOCALIZAÇÃO DO TRECHO A SER ANALISADO....................................... 78

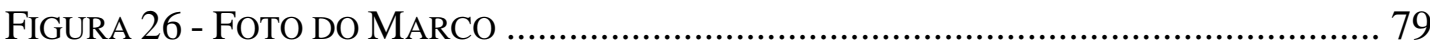

FIGURA 27 - EQUIPAMENTO DA TRIMBLE 4000SST ................................................ 80

FIGURA 28 - EQUIPAMENTO DA WILD SR 9400 ...................................................... 81

FIGURA 29 - PRIMEIRA ETAPA DO LEVANTAMENTO CiNEMÁTICO................................. 83

FigURA 30 - SEgUndA ETAPA DO LEVANTAMENTO CinEMÁTICO................................ 83

Figura 31 - REPRESENTAÇÃo GRÁFICA DA RodOVIA No Plano XY POR UM ARQUIVO

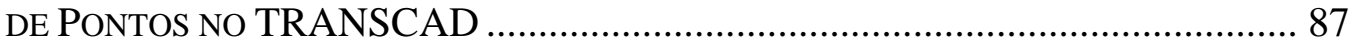

Figura 32 - Zoom do TREcho Inicial da Rodovia PRÓXimo A Rio Claro............ 87

FIGURA 33 - REPRESENTAÇÃo GRÁFICA DA RODOVIA NO PLANO XY POR UM ARQUIVO

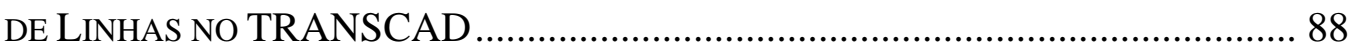

Figura 34 - ZoOm do TREcho Inicial DA Rodovia PróXimo A Rio ClaRo............ 88

Figura 35 - Rodovia EM Planta (Plano XY) (CoORdenadas UTM).................... 90

Figura 36 - Rodovia EM Perfil (Plano XZ) (CoORdenadas UTM) ...................... 90

Figura 37 - LOCALIZAÇÃo EM Planta do EXEMPLO 1 (COORDENADAS UTM) ........ 92

Figura 38 - LOCALIZAÇÃo DO EXEMPLO 1 NO PERFIL DA ESTRADA (COORDENADAS

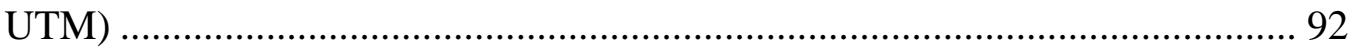

Figura 39 - RAIO dA CURVA Horizontal do EXEMPlo 1 ObTIDO ATRAVÉS DO

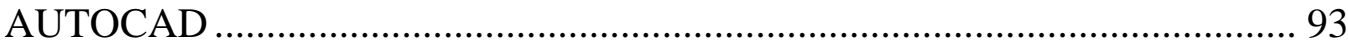

Figura 40 - PERfil LONGitUdinAl dA Rodovia ObTido AtravÉs do EXCEL ...... 97 Figura 41 - LOCALizaÇÃo DA CURVA Vertical do EXemplo 2 EM Planta

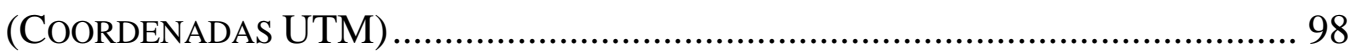

Figura 42 - LocalizaçÃo da Curva Vertical do Exemplo 2 EM Perfil

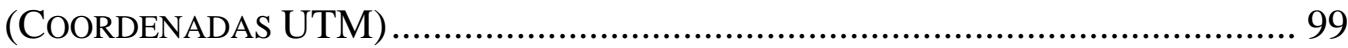

Figura 43 - CURVA VERTICAL DO EXEMPLO 2 NO AUTOCAD .................................. 99 
Figura 44 - CURVA VerTiCAL DO EXEMPLO 2 NO EXCEL........................................ 100

FiguRA 45 - SUPERPOSIÇÃO DAS DUAS SOLUÇÕES DO EXEMPLO 2 NO AUTOCAD 100

FiguRA 46 - TRECHO RETO RotAciONADO DE 12 (COORDENADAS UTM) .............. 101

Figura 47 - LOCALização da Curva Horizontal do Exemplo 3 EM Planta

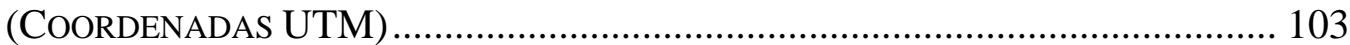

Figura 48 - Ampliação da Curva Horizontal do Exemplo 3 (COORDENAdAS UTM) 104

Figura 49 - Curva Vertical do Segmento AB Determinada Através do

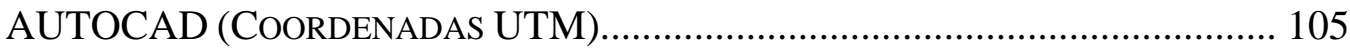

Figura 50 - CURVA VERTICAL EXATA DO EXEMPLO 3 NO EXCEL........................... 105

FigURA 51 - TRECHO RotACIONADO DE $40^{\circ}$ (COORDENADAS UTM) ....................... 106

Figura 52 - TRECHO RotACIONADO DE $10^{\circ}$ (COORDENADAS UTM) ........................ 106 


\section{LISTA DE TABELAS}

TABela 1 - ReduÇão Esperada nA TAXa de EnVolvimento de CAminhões EM Acidentes EM Rodovias InTEREstaduais Depois DA MElHORIA DE UM ELEMENTO GEOMÉTRICO ............................................................................ 10

Tabela 2 - Porcentagem de Redução nos Acidentes deVido ao Alargamento Da Pista, Acostamento Pavimentado e Acostamento

NÃO PAVIMENTADO 14

Tabela 3 - Elementos da CuRva Que São Potenciais Candidatos Para o Estudo da RelaÇÃo do Projeto Geométrico e a SEguranÇa. ..................... 18 Tabela 4 - Equações para Prever as Taxa de Acidentes para Diferentes

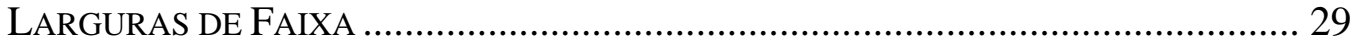

TABELA 5 - ERRO VERSUS DISTÂNCIA PARA O EDM E O GPS ..................................... 48

TABEla 6 - Resultados no TESTE NA FRANÇA EM 1988 COM EDM Óticos ............. 49

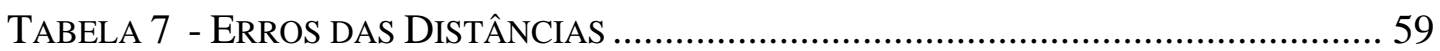

TABela 8- PrecisÃo do MÉtodo EstÁtico .............................................................. 75

TABela 9- CoORdenadas dos Marcos em CoORdenadAs GeOdÉSICAS................ 85 TABela 10 - Arquivo de Entrada do TRANSCAD Para CRiar um ARquivo de LINHAS 86

Tabela 11- Arquivo de Entrada do TRANSCAD Para Criar um Arquivo de Pontos. .86 


\section{LISTA DE ABREVIATURAS E SIGLAS}

A/S - Antispoofing

AASHTO - American Association of Stat Highway and Transportation Officials

C/A - Coarse/ Aquisition

DNER - Departamento Nacional de Estradas de Rodagem

DoD - Department of Defense

DOP - Dilution of Precision

EDM - Eletronic Distande Measurement

FHWA - Federal Highway Administration

GDOP - Geometric Dilution of Precision

GPS - Global Positioning System

HDOP - Horizontal Dilution of Precision

INS - Inertial Navigation System

ISS - Inertial Surveying System

$\mathrm{N}$ - Ambiguidade

NASA - National Aeronautics and Space Administration

NAVSTAR GPS - Navigation System with Time Ranging Global Positioning System

OECD - Organization for Economic Cooperation and Development

ODM - Optical Distance Measurement

OTF - On The Fly

P - Protected

PARE - Programa de Redução de Acidentes de Trânsito

PDOP - Position Dilution of Precision

RAT - Relatório de Acidentes de Trânsito

S/A - Selective Availability 
SIG - Sistema de Informação Geográfica

SIG-T - Sistema de Informação Geográfica para Transportes

TDOP - Time Dilution of Precision

TRB - Transportation Research Board

UERE - User Equivalent Range Error

UTM - Universal Transverse Mercator

VDM - Volume Médio Diário

VDOP - Vertical Dilution of Precision

ZUPT - Zero Velocity Update 


\title{
LISTA DE SÍMBOLOS
}

\author{
$\sigma_{\mathrm{r}}$ - Desvio Padrão Associado ao Posicionamento \\ $\Delta \varphi$ - Fase Acumulada Observada \\ $\varphi$ - Fase \\ M - Distância entre o Eixo da Pista e o Obstáculo \\ Df - Distância de Frenagem \\ f - Coeficiente de Atrito \\ i - Inclinação da Rampa \\ e - Superelevação
}




\section{RESUMO}

LOTTI, Cynthia P. (1997). Um Método Expedito de Representação da Geometria de uma Rodovia na Forma em que foi Efetivamente Construída. São Carlos, 1997, 145p. Dissertação (Mestrado) - Escola de Engenharia de São Carlos, Universidade de São Paulo.

Diversas pesquisas realizadas no Brasil e no exterior nos últimos anos permitem inferir que existe uma relação causal entre a geometria das rodovias e a incidência de acidentes em determinadas locais. Uma das principais dificuldades nesses estudos tem sido a representação gráfica da geometria da via na forma em que foi efetivamente construída. O advento da tecnologia do GPS associada a modernas técnicas de CAD abre novas possibilidades em termos de se propor um método expedito de criar uma base geográfica de informação à qual poderá associar-se posteriormente dados de acidentes, sinalização da via, condições do pavimento, etc. A proposta da dissertação de mestrado é desenvolver o método de representação geométrica da estrada usando a técnica cinemática do GPS. Para avaliar o desempenho do método proposto foi realizado o levantamento de um trecho de 30 km da rodovia SP-127 Fausto Santo Mauro conectando Rio Claro a Piracicaba. Através do arquivo de dados resultante do levantamento foi possível desenhar a rodovia em planta e em perfil com um nível de precisão suficiente para a construção de uma base geográfica de um SIG. Relatam-se algumas dificuldades de representação gráfica no TRANSCAD, no LISCAD e no AUTOCAD.

Palavras Chaves: Rodovia, Acidentes, Geometria, GPS, SIG 


\begin{abstract}
LOTTI, Cynthia P. (1997).A Rapid Method of Road Geometry as Built Representation. São Carlos, 1997, 145p. Dissertação (Mestrado) - Escola de Engenharia de São Carlos, Universidade de São Paulo.

Several studies in Brasil and abroad in the near past lead to the conclusion that there is a causal relationship between highway geometry and accident incidence at certain locations on the road. One of the major difficulties described in these studies is the grafic representation of the road geometry as built.The advent of the GPS technology, associated with modern CAD techniques, opens new possibilities in terms of an expedite method to criate a geographic information base that can be associated to accident data, traffic sign data, pavement conditions data, etc. A method to graphically represent the roadway geometry using the kinematic GPS techique is proposed at the level of a MSc thesis. In order to evaluate the proposed method's performance, a $30 \mathrm{~km}$ segment of SP-127 Fausto Santo Mauro Highway connecting Rio Claro to Piracicaba was surveyed. The graphical representation of the horizontal and vertical profile of the road that resulted from the surveying method is shown. Some of the difficulties in graphically representing the road with TRANSCAD, LISCAD and AUTOCAD are described.
\end{abstract}

Key Words : Highway, Accidents, Geometry, GPS, SIG 


\section{INTRODUÇÃO}

\subsection{CONSIDERAÇÕES GERAIS}

O número de acidentes nas rodovias brasileiras tem aumentado consideravelmente nos últimos anos. Esta situação preocupa tanto os governantes como a população brasileira. O nível de segurança não acompanhou o aumento do tráfego que ocorreu devido ao crescimento econômico do país decorrente da expansão da produção industrial e agropecuária nas últimas décadas.

Além do aumento do tráfego, houve evolução tecnológica considerável dos veículos tanto de carga como de passageiros. Em particular, no transporte de carga estão disponíveis no mercado veículos mais potentes com maior capacidade unitária de transporte. Entretanto, as rodovias brasileiras, principalmente de pista simples e mão dupla, que foram construídas nas décadas de 60 e 70, não conseguem absorver este avanço tecnológico. Intuitivamente acredita-se que sucessões de curvas de pequeno raio, rampas muito longas e íngremes, curvas em aclives e declives são uma das prováveis causas dos acidentes.

Admite-se a hipótese de que, nos pontos onde a geometria da via possa levar a uma decisão incorreta do condutor do veículo, o índice de acidentes seja elevado. Mudanças bruscas dos elementos geométricos não correspondem às expectativas do motorista e, freqüentemente não fornecem um tempo de decisão adequado. 
Também outros parâmetros das rodovias como: a sinalização, as condições do pavimento e das áreas adjacentes à rodovia devem ser estudadas visando estabelecer referências para a construção de novas rodovias, de forma que estas sejam compatíveis com a solicitação de tráfego veicular a que se destinam.

Várias pesquisas, foram realizadas nos últimos anos no exterior, principalmente nos Estados Unidos, Canadá e Alemanha, visando encontrar a relação entre os elementos da geometria da rodovia, tais como largura da pista e do acostamento, alinhamento vertical e horizontal, pontes e interseções, e os acidentes, de forma a estabelecer as principais medidas a serem tomadas para melhorar a segurança. CHOUEIRI et al. (1994) apresentam em sua revisão bibliográfica, pesquisas sobre acidentes realizadas a partir de 1953 até 1994.

Por outro lado, com exceção do trabalho de NOGUEIRA (1994) e do trabalho desenvolvido por RABBANI et al. (1994) não se tem conhecimento de trabalhos equivalentes realizados no Brasil, apesar do alto índice de acidentes em nossas rodovias. Segundo estatísticas do DNER 67021 acidentes de trânsito foram registrados nas rodovias federais no ano de 1992, sendo que no estado de São Paulo, foram registrados 8217 acidentes (12,2\%) no mesmo ano. (DNER, 1995)

Estudos dessa natureza requerem uma base de dados bastante ampla em termos da descrição dos acidentes e da geometria da rodovia e uma das principais dificuldades encontradas em se montar esta base é a reconstituição gráfica da geometria da via na forma em que foi realmente construída. Este trabalho visa contribuir no sentido de preencher essa lacuna, com a proposta de um método rápido e preciso utilizando a tecnologia emergente do posicionamento com GPS (Global Positioning System).

Para facilitar a visualização da geometria da via com os dados obtidos através do GPS, propõe-se a construção de uma interface com o Sistema TRANSCAD que é um software específico de aplicação do Sistema de Informações Geográficas (SIG) em transportes. 
Utiliza-se o método cinemático de GPS para determinar a geometria da via. Neste método, um carro equipado com um receptor GPS percorre a rodovia e são obtidas as coordenadas $\mathrm{X}, \mathrm{Y}, \mathrm{Z}$ de um grande número de pontos desta, possibilitando desenhála em planta e perfil.

NOVAK (1995) realizou um levantamento topográfico semelhante ao proposto utilizando o método cinemático puro. Na Universidade de Ohio foi desenvolvido um programa que cria mapas digitais e realiza o inventário das rodovias através de um veículo de coleta de dados, GPSvan . O desenvolvimento da GPSvan foi iniciado em 1989 para um projeto financiado por 38 Agências Estaduais de Transportes dos Estados Unidos (U.S. State Transportation Agencies), o Federal Highway Administration, a NASA, a província de Alberta (Canadá), o DMA, e algumas empresas privadas (JOHNSON et al., 1992 apud NOVAK 1995). O primeiro protótipo da GPSvan é mostrado na figura 1. Ela integra um receptor GPS, um sistema inercial e câmeras de vídeo coloridas em um furgão.

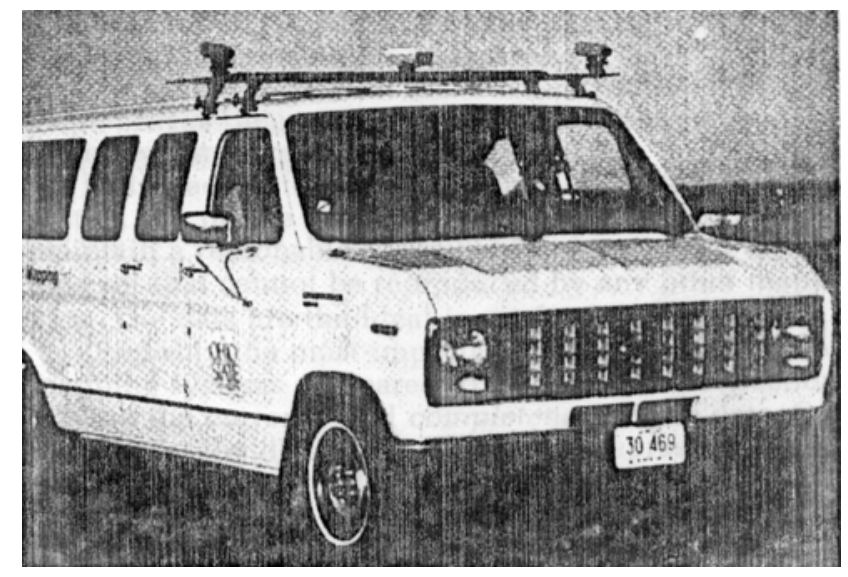

Figura Erro! Argumento de opção desconhecido.- GPSvan

Fonte: NOVAK (1995) página 498

Enquanto movimenta-se ao longo da rodovia, a GPSvan coleta dados do alinhamento junto com imagens digitais e de vídeo. O alinhamento da rodovia é armazenado em um banco de dados espacial enquanto que as imagens são armazenadas em um banco 
de dados relacionado com as posições absolutas da rodovia. A precisão absoluta obtida para o alinhamento da rodovia foi de 1 a $3 \mathrm{~m}$ com a ambigüidade resolvida através da combinação dos dados de GPS com os dados obtidos através de Sistemas Inerciais de Navegação (INS).

No Brasil, o Prof. Segundo Carlos Lopes da Universidade Federal de São Carlos e o aluno de mestrado da Departamento de Transportes da Escola de Engenharia de São Carlos, Arthur Pantoja, utilizaram o método cinemático para realizar o levantamento de uma rodovia em planta e perfil visando comparar a precisão dos dados obtidos com GPS com os dados obtidos pelos métodos topográficos tradicionais.

\subsection{JUSTIFICATIVA}

A segurança nas rodovias brasileiras tornou-se crítica nos últimos anos. Diminuir o número de acidentes tornou-se uma das metas do atual Governo Federal através da criação de uma Secretária Especial dentro da qual se desenvolve o projeto PARE (Programa de Redução de Acidentes de Trânsito).

Além das medidas educativas de prevenção dos acidentes que visam mudar o comportamento do motorista brasileiro, existem fortes suspeitas de que são necessárias medidas amplas e profundas em relação ao projeto geométrico das rodovias.

O grande problema no estudo da relação entre a geometria e os acidentes é a base de dados disponível. Em relação aos acidentes, estes podem ser retirados dos relatórios de acidentes (RAT) fornecidos pelas polícias rodoviárias. Quanto à geometria, a primeira idéia que surge, é retirar os dados dos projetos, mas não há infelizmente, 
nenhuma garantia de que a rodovia tenha sido construída exatamente conforme as especificações do projeto original. Visando suprir esta deficiência, propõe-se um método rápido para determinar a geometria da rodovia na forma em que ela foi realmente construída, através do Sistema de Posicionamento Global - GPS.

Dado a experiência anterior no trabalho de NOGUEIRA (1994), a premência de avançar no conhecimento sobre o assunto em nosso país e a inexistência de um pacote comercial disponível para a restituição geométrica pretendida justifica-se a realização dessa pesquisa em nível de uma dissertação de mestrado.

\subsection{OBJETIVO}

O objetivo deste trabalho é apresentar um método expedito de reconstituição da geometria de uma rodovia na forma em que foi efetivamente construída, para que estes dados sejam posteriormente utilizados na análise da relação dos acidentes com o projeto geométrico e de outras características da via que afetam a segurança tais como: sinalização, estado do pavimento e condições do entorno da pista.

\subsection{ORGANIZAÇÃO DO TRABALHO}

Este trabalho apresenta oito capítulos. O primeiro capítulo contém a introdução à discussão a respeito do assunto, o objetivo e a justificativa do trabalho.

O segundo capítulo apresenta a revisão bibliográfica. A primeira parte deste refere-se à relação de acidentes com a geometria da rodovia, onde descrevem-se alguns trabalhos realizados por outros pesquisadores que buscaram estabelecer esta relação. 
Na segunda parte, explicam-se os princípios do Sistema de Informação Geográfica (SIG) e do TRANSCAD. Na terceira parte são apresentados os principais métodos que podem ser utilizados na reconstituição da geometria, sendo que o Sistema Global de Posicionamento (GPS) é apresentado com maiores detalhes.

No terceiro capítulo descreve-se o método a ser utilizado no levantamento dos dados. O quarto capítulo traz o levantamento feito em uma rodovia para que se possa verificar a exequibilidade do método proposto.

O quinto capítulo apresenta os resultados do levantamento. O sexto capítulo traz as principais conclusões e recomendações a respeito do método e sugestões de continuidade deste trabalho. 


\section{REVISÃO BIBLIOGRÁFICA}

\subsection{A RELAÇÃO ENTRE ACIDENTES E PROJETO GEOMÉTRICO}

De um modo geral, a relação entre a segurança e as características da rodovia não está ainda bem quantificada e a ligação entre a relação e as normas de projeto de rodovias não é nem direta ou explícita. A American Association of State Highway and Transportation Officials (AASHTO), órgão normativo de caráter nacional nos EUA, tem historicamente constituído a base das normas de projeto não só do Brasil, mas de muitos países do mundo ocidental que, contam com comitês de técnicos por uma razão ou outra, não de projetistas de rodovias para realizar este trabalho. $\mathrm{O}$ processo de normatização do projeto geométrico adotado pela AASHTO leva em conta não somente a segurança, mas também o custo de construção e operação da rodovia e outros fatores tais como o efeito de projeto nas operações de tráfego e na capacidade, implicações de manutenção, consistência do projeto com as condições de tráfego (TRB, 1987).

As características da rodovia afetam a segurança por (TRB, 1987):

1. influenciar a habilidade do motorista em manter o controle do veículo e identificar as situações perigosas. Características significantes incluem a largura da pista, alinhamento, distância de visibilidade, superelevação e características do superfície do pavimento. 
2. influenciar o número e tipo de oportunidades que existem em conflitos entre veículos. As características importantes incluem controle de acesso, projeto da interseção, número de faixas;

3. afetar as conseqüências de um veículo fora de controle saindo da pista. Características significantes incluem tipo e largura do acostamento, condições da área adjacente e "guardrail”;

4. afetar o comportamento e a atenção do motorista, particularmente, a escolha da velocidade de viagem. O comportamento do motorista é afetado potencialmente por todos os elementos do ambiente da rodovia.

Observa-se, portanto que, além das características geométricas, uma série de outros fatores afeta a segurança das rodovias, tais como: os outros elementos de todo o meio ambiente da rodovia (por exemplo: as condições do pavimento, clima e iluminação), tráfego, regulamentação do tráfego, características do motorista (intoxicação, idade), e características do veículo (tamanho, peso, capacidade de frenagem).

Nesse conceito é comum que o efeito do projeto geométrico como fator concorrente para o acidente seja encoberto pelos outros fatores. Principalmente, em acidentes com um único veículo. Ás vezes, o veículo sai da pista por falha mecânica ou humana. Mas, o acidente pode ter conseqüências maiores se o acostamento ou a área adjacente a este não apresentam uma condição favorável. Esta interação entre a rodovia, motorista e veículo dificulta os esforços para estimar a influência de cada um destes fatores no acidente, e a determinação das formas de intervenção para reduzir o número de acidentes e/ou sua gravidade.

Para CHOUEIRI et al. (1994) muitos fatores podem exibir uma influência mensurável no comportamento do motorista e na segurança do tráfego em rodovias de pista simples de mão dupla. Estes incluem, mas não se limitam a:

1. Fatores Humanos, como: julgamento indevido com relação a rodovia à frente e ao tráfego; velocidade; dirigir sob o efeito de álcool e drogas; inexperiência 
(motoristas jovens); deficiência (especialmente o segmento idoso da população); e sexo (CHOUERI et al. 1991, LAMM et al. 1991 apud CHOUERI et al. 1994).

2. Características Físicas do Local como: alinhamento horizontal e vertical; seção transversal combinada com o grau de desenvolvimento da área adjacente à rodovia; e controle do acesso.

3. Presença e Ação de Tráfego, como: a composição e volume do tráfego; e as variações sazonais e diárias.

4. Questões Legais, como: as leis obrigatórias estaduais e federais; tipo de controle de tráfego; e o grau de policiamento.

5. Fatores Ambientais, tais como: clima e condições do pavimento.

6. Deficiências dos Veículos, tais como: pneus, freios e idade.

Durante mais de 50 anos, pesquisadores têm tentado medir os efeitos de várias características da rodovia na segurança. Apesar destes esforços, surpreendentemente ainda pouco é conhecido sobre o decréscimo da taxa de acidentes resultante da melhora do projeto geométrico. Em parte, esta situação lamentável pode ser atribuída pela dificuldade inerente à pesquisa sobre acidentes (TRB,1987):

1. os acidentes não são freqüentes, portanto estudos estatísticos idôneos necessitam de dados consistentes coletados durante longos períodos em muitos quilômetros de rodovias;

2. muitos fatores, alguns relacionados com o ambiente da rodovia, o motorista e o veículo, contribuem interativamente para a ocorrência e severidade do acidente. Informações descrevendo os fatos relacionados são raramente incluídas na base de dados dos acidentes. Mesmo com uma base de dados razoavelmente completa, pesquisadores são freqüentemente incapazes de classificar os efeitos atribuídos a uma característica da rodovia de interesse. Experimentos controlados são difíceis de serem projetados e conduzidos;

3. alguns fatores, tais como o desempenho e os valores dos danos do veículo, que suportam a relação entre a segurança e o projeto da rodovia, mudam com o tempo, portanto a relação desenvolvida em certo momento pode não ser representativa em anos posteriores. 
Um exemplo de um estudo estatístico sobre acidentes e projeto geométrico é apresentado em MIAOU et al. (1993) que desenvolveram um modelo de regressão poissoniano para estabelecer a relação entre os acidentes e o projeto geométrico da rodovia. Na teoria o modelo pode ser aplicado para qualquer classe de rodovia, configuração de veículo, tipo de severidade do acidente de interesse. O modelo apresentado dá ênfase a todos os tipos de acidentes envolvendo caminhões com mais de 4545 kg (10000 lb) em uma classe particular de rodovia.

MIAOU et al. desenvolveram oito modelos para avaliar os efeitos das variáveis nos acidentes. O modelo cinco inclui as variáveis do projeto geométrico (curvatura horizontal, comprimento original da curva, rampa, comprimento original da rampa, largura do acostamento pavimentado). Baseado neste modelo, as taxas de envolvimento dos caminhões em acidentes para diferentes combinações de VDM/faixa, curvatura horizontal, comprimento da curva, rampa, comprimento da rampa, largura do acostamento pavimentado, e a porcentagem de caminhões foram determinadas. A redução do número esperado de envolvimento de caminhões em acidentes e seu desvio padrão estimado causado pelo melhoramento da curva horizontal, rampa vertical, largura do acostamento pavimentado da seção da rodovia foi calculada. O exemplo assume que não houve qualquer mudança na viagem dos caminhões após a melhoria. As reduções esperadas após a melhoria de um elemento geométrico são mostradas na Tabela 1. 
Tabela 1 - Redução Esperada na Taxa de Envolvimento de Caminhões em Acidentes em Rodovias Interestaduais Depois da Melhoria de Um Elemento Geométrico

\begin{tabular}{|c|c|c|c|c|c|}
\hline \multirow{2}{*}{$\begin{array}{c}\text { Comprimento } \\
\text { Original da Curva } \\
{[\mathrm{m}]} \\
\end{array}$} & \multicolumn{5}{|c|}{ Curvatura Horizontal (HC) em graus/arco de $30,48 \mathrm{~m}: 2^{\circ} \leq \mathrm{HC} \leq 12^{\circ}$} \\
\hline & Redução de $1^{\circ}$ & Redução de $2^{\circ}$ & Redução de $3^{\circ}$ & Redução de $4^{\circ}$ & Redução de $5^{\circ}$ \\
\hline 160,9 & $\begin{array}{c}10,6 \% \\
( \pm 2,5 \%) \\
\end{array}$ & \begin{tabular}{|c|}
$20,1 \%$ \\
$( \pm 4,5 \%)$ \\
\end{tabular} & \begin{tabular}{|c|}
$28,6 \%$ \\
$( \pm 6,0 \%)$ \\
\end{tabular} & \begin{tabular}{|c|}
$36,2 \%$ \\
$( \pm 7,2 \%)$ \\
\end{tabular} & \begin{tabular}{|c|}
$43,0 \%$ \\
$( \pm 8,1 \%)$ \\
\end{tabular} \\
\hline 402,2 & $\begin{array}{c}13,7 \% \\
( \pm 1,9 \%)\end{array}$ & $\begin{array}{c}25,5 \% \\
( \pm 3,3 \%)\end{array}$ & $\begin{array}{c}35,7 \% \\
( \pm 4,2 \%)\end{array}$ & $\begin{array}{c}44,5 \% \\
( \pm 4,9 \%)\end{array}$ & $\begin{array}{c}52,1 \% \\
( \pm 5,3 \%)\end{array}$ \\
\hline 804,5 & $\begin{array}{c}18,6 \% \\
( \pm 2,7 \%)\end{array}$ & $\begin{array}{c}33,8 \% \\
( \pm 4,4 \%)\end{array}$ & $\begin{array}{c}46,1 \% \\
( \pm 5,4 \%)\end{array}$ & $\begin{array}{c}56,1 \% \\
( \pm 5,8 \%)\end{array}$ & $\begin{array}{c}64,3 \% \\
( \pm 6,0 \%)\end{array}$ \\
\hline 1206,7 & $\begin{array}{l}23,2 \% \\
( \pm 4,3 \%)\end{array}$ & $\begin{array}{c}41,1 \\
( \pm 6,6 \%)\end{array}$ & $\begin{array}{c}54,8 \% \\
( \pm 7,7 \%)\end{array}$ & $\begin{array}{c}65,3 \% \\
( \pm 8,0 \%) \\
\end{array}$ & $\begin{array}{c}73,4 \% \\
( \pm 7,8 \%)\end{array}$ \\
\hline$\geq 1609$ & $\begin{array}{c}27,6 \% \\
( \pm 5,8 \%)\end{array}$ & $\begin{array}{c}47,6 \% \\
( \pm 8,6 \%)\end{array}$ & $\begin{array}{c}62,1 \% \\
( \pm 9,6 \%)\end{array}$ & $\begin{array}{c}72,5 \% \\
( \pm 9,5 \%)\end{array}$ & $\begin{array}{c}80,1 \% \\
( \pm 9,0 \%)\end{array}$ \\
\hline
\end{tabular}

Fonte: MIAOU et al. (1993) página 21

Dados sobre viagens mostram que as viagens de caminhões aumentaram de 668 bilhões veículos.Km para 1 trilhões veículos.Km de 1980 a 1989 nos Estados Unidos. Se esta tendência continuar, as viagens com caminhões excederão os 1,67 trilhões de veículos.Km no final deste século. Este aumento nas viagens de caminhões causa problemas operacionais e de segurança nas rodovias. Estes problemas resultam da dimensão dos caminhões bem como das suas características de aceleração e desaceleração. A ocorrência de acidentes com caminhões é diferente da ocorrência dos acidentes com veículos de passageiros devido às características especiais dos caminhões (MOAMEDSHAH et al. 1993):

1. os caminhões são mais pesados e suas dimensões são maiores comparadas com os veículos de passageiros;

2. os caminhões têm capacidade de aceleração menos efetiva e grande dificuldade de manter sua velocidade em rampas ascendentes;

3. os caminhões têm uma resposta de desaceleração menor quando freiam. 
As ocorrências mais importantes dos acidentes com caminhões são em rampas e curvas horizontais. Rampas descendentes podem conduzir a um aumento excessivo da velocidade dos caminhões resultando em acidentes como saída da pista e colisões traseiras com veículos lentos em movimento, em contrapartida em rampas ascendentes os caminhões andam lentamente, resultando em colisões traseiras com os veículos mais rápidos. Curvas horizontais podem contribuir com os problemas de capotamento de caminhões com centro de gravidade alto ou quando a carga deslocase ao negociar a curva. Em rodovias com duas faixas de tráfego, caminhões podem encontrar outro veículo na faixa oposta enquanto negociam curvas fechadas (MOAMEDSHAH et al. 1993).

Para assegurar o seu uso seguro, as rodovias devem ser projetadas e construídas de forma que acomodem os tipos e volumes dos veículos em operação. A compatibilidade entre a geometria da rodovia e as características dos veículos pode ter sido alterada de forma a afetar a severidade e freqüência dos acidentes devido a evolução de características importantes dos veículos tais como: tamanho, peso, desempenho. Devido a distribuição econômica, uma grande variedade de modelos de veículos, tanto de passageiros como de carga, trafegam por nossas rodovias. Atualmente, a velocidade de viagem, mesmo em rodovias de pista simples de mão dupla é acima de $100 \mathrm{~km} / \mathrm{h}$. Esta velocidade é facilmente atingida pelos veículos de passageiros, que a cada dia estão mais velozes e equilibrados. Mas, nestas mesmas rodovias trafegam caminhões velhos sobrecarregados, que trafegam em subidas à 20 $\mathrm{km} / \mathrm{h}$ ou menos. Esta disparidade entre as velocidade de operação de caminhões e automóveis acaba ocasionando ultrapassagens irregulares, as quais freqüentemente, resultam em sérios acidentes.

Para que os valores de novos parâmetros do projeto geométrico sejam determinados de forma a considerar as características dos veículos que nela trafegam, e para que as rodovias novas sejam construídas de forma a incorporar maiores níveis de segurança e as rodovias atuais possam ser remodeladas para elevar o seu nível de segurança, a relação entre os elementos do projeto geométrico e a segurança deve ser estudada. Apresentam-se a seguir alguns exemplos de estudos já realizados no exterior que 
mostram como alguns elementos do projeto geométrico interferem na segurança rodoviária.

\subsubsection{LARGURA DA PISTA}

As pesquisas têm mostrado que é necessário utilizar uma largura adequada do pavimento para assegurar que operações sejam seguras. A largura necessária para manobras e transporte seguro são geralmente o resultado da dimensão dos veículos e da desobstrução lateral. Se esta largura não for suficiente, pode-se gerar um impasse com a segurança do tráfego.(CHOUERI et al. 1994).

Faixas e acostamentos mais largos fornecem ao motorista maiores oportunidades para uma recuperação segura quando os veículos saem da pista (um fator importante para acidentes com um único veículo) e aumento da separação lateral entre os veículos durante a ultrapassagem (TRB, 1987).

Um estudo realizado por McCARTHY (1981 apud CHOUERI et al. 1994) sobre os efeitos do alargamento das pistas em 17 locais, nos quais as faixas foram aumentadas de 2,7 m e 3,0 m para 3,4 $\mathrm{m}$ e 3,7 $\mathrm{m}$, respectivamente, mostrou que o aumento da largura da faixa reduziu a taxa de acidentes fatais significantemente (22 por cento) e causou um decréscimo na taxa total dos acidentes.

CHOUERI et al. (1987 apud CHOUERI et al. 1994) e LAMM E CHOUERI (1987 apud CHOUERI 1994) que estudaram o impacto conjunto de vários parâmetros grau da curva, comprimento da curva, taxa de superelevação, gradientes acima de 5\%, distância de visibilidade, largura da pista, largura do acostamento, VDM - nas taxas de acidentes em 261 seções de curvas no Estado de Nova York, estabeleceram uma relação marginal negativa entre a largura do pavimento e a taxa de acidente.

Análises estatísticas realizadas por ZEGEER et al. (1992 apud CHOUERI 1994) das relações de 12123 acidentes em 10900 curvas horizontais em rodovias com duas 
faixas de tráfego no Estado de Washington determinaram uma redução de 21 por cento na taxa de acidentes para um aumento de 1,2 $\mathrm{m}$ da faixa.

ZEGEER et al. (1992) apresentam os fatores de redução dos acidentes que foram estimados para vários montantes de aumento da pista, do acostamento pavimentado, e não pavimentado em curvas (Tabela 2).

Tabela 2 - Porcentagem de Redução nos Acidentes devido ao Alargamento da Pista, Acostamento Pavimentado e Acostamento não Pavimentado

\begin{tabular}{|c|c|c|c|}
\hline $\begin{array}{c}\text { Alargamento total da pista } \\
\text { ou do acostamento }\end{array}$ & \multicolumn{3}{|c|}{ Porcentagem de Redução de Acidentes } \\
\hline Total [m] & Alargamento da Pista & $\begin{array}{c}\text { Alargamento do } \\
\text { Acostamento } \\
\text { Pavimentado }\end{array}$ & $\begin{array}{c}\text { Alargamento do } \\
\text { Acostamento não } \\
\text { Pavimentado }\end{array}$ \\
\hline 0,6 & 5 & 4 & 3 \\
\hline 1,2 & 12 & 8 & 7 \\
\hline 1,8 & 17 & 12 & 10 \\
\hline 2,4 & & 15 & 13 \\
\hline 3,0 & $*$ & 19 & 16 \\
\hline 3,7 & $*$ & 21 & 18 \\
\hline 4,3 & $*$ & 25 & 21 \\
\hline 4,9 & $*$ & 28 & 24 \\
\hline 5,4 & $*$ & 31 & 26 \\
\hline 6,1 & $*$ & 33 & 29 \\
\hline
\end{tabular}

${ }^{1}$ valores de alargamento da pista correspondem a um aumento máximo de 2,4 m para 3,7 m para um total de 1,2 m por faixa, ou um total de 2,4 m de alargamento.

Fonte: ZEGEER (1992) página 17 
GOLDSTINE (1991) estabeleceu a redução da taxa de acidentes com o aumento da largura da pista de rodovias de duas faixas de tráfego no Novo México, E.U.A. Para este estudo foram escolhidos 25 projetos 3R (Reabilitação, Restauração e Reabilitação) realizados nestas rodovias de 1981 a 1986. Após a análise de todos os dados (acidentes, geometria e VDM) através do teste T, encontrou-se uma redução na taxa de acidentes de 53 \% para rodovias com VDM menor que 1000 cuja largura da pista era de 7,9 m a 9,8 $\mathrm{m}$ antes do projeto e foi aumentada até 9,8 $\mathrm{m}$. A taxa de acidentes foi reduzida em 45 \% para rodovias com VDM entre 1000 e 2000 cuja largura da pista era de 7,9 m a 8,5 m foi aumentada até $11 \mathrm{~m}$. A determinação do desempenho de rodovias com VDM maior que 2000 de $11 \mathrm{~m}$ de largura (após o término do projeto 3R) necessitará de investigações futuras. A taxa de acidentes foi reduzida em 36 \% para rodovias com VDM maior que 2000. cuja largura foi aumentada de 7,3 a 9,8 para $13,4 \mathrm{~m}$.

ZEGEER \& DEACON (1987) fizeram um levantamento bibliográfico com o intuito de desenvolver através das fontes publicadas um modelo que estimasse o efeito das condições do pista e do acostamento nos acidentes em rodovias com duas faixas de tráfego. Com base nos resultados encontrados, pode-se concluir que:

- as condições da pista e do acostamento afetam diretamente os acidentes onde o veículo sai da pista (Run-Off-Road - ROR) e quando o veículo choca-se com outro veículo que trafegava no sentido oposto (Opposite Direction - OD) (incluindo colisão frontal e abalroamento);

- a taxa de acidentes do tipo ROR e OD diminui com o aumento da largura da pista. Contudo, os efeitos marginais dos incrementos da largura da pista diminuem mesmo com o aumento da largura da base da pista ou da base do acostamento;

- A largura da pista tem um efeito maior do que a largura do acostamento nas taxas de acidentes; 


\subsubsection{ALINHAMENTO HORIZONTAL}

É mais provável que o acidente ocorra em curvas horizontais em rodovias de pista simples do que em segmentos retos devido ao aumento da demanda sobre o motorista. O efeito na segurança de uma curva em particular é influenciado não somente pelas características geométricas dessa curva, mas também pela geometria dos segmentos adjacentes. O perigo é particularmente intenso quando a curva é inesperada, como por exemplo quando esta aparece depois de uma reta longa ou quando está escondida por uma curva vertical convexa.(TRB, 1987).

Em termos gerais, pode-se concluir que as curvas apresentam problemas especiais para os motoristas. Quando as curvas são particularmente fechadas e quando não existe nenhuma transição, estas geram problemas com relação ao comportamento do motorista e do veículo. Além disso, quando tais curvas ocorrem juntamente com outros problemas geométricos (como rampas íngremes, pistas estreitas, acostamentos estreitos), os acidentes são inevitáveis. ( REINFURT et al. 1991)

Desde que seções de curvas exijam mais do motorista, então estas seções têm uma taxa de acidentes significantemente mais elevada do que em seções de tangente, como é indicado em muitos estudos (ZEGEER et al. 1992; LIN 1990; TRB 1987; LAMM 1984 apud TALARICO 1994). De fato, as taxas de acidentes encontradas eram 1,5 a 4 vezes superiores àquelas em seções de tangente para seções similares de rodovia (GLENNON et al. 1985 apud TALARICO 1994). Pesquisas indicam que a suavização das curvas é um dos métodos mais efetivos para diminuir as taxas de acidentes em curvas horizontais (ZEGEER et al. 1992 apud TALARICO 1994). 
REINFURT et al. (1991), com base em trabalhos anteriores, chegam às seguintes conclusões a respeito dos tratamentos para os problemas existentes com as curvas:

1. a suavização das curvas fechadas existentes apresenta um dos maiores potenciais (em relação aos outros melhoramentos) para a redução das freqüências de colisões;

2. o alargamento de rodovias nas curvas é eficaz na produção de menores taxas de acidentes;

3. a presença de transições e superelevação adequada está associada a reduções pequenas mas significantes nos acidentes;

Para GLENNON (1987) muitos estudos têm indicado que as curvas horizontais exibem taxas de acidentes maiores que seções de tangentes e que a taxa de acidentes aumenta com o aumento do grau da curva. Mas, o grau da curva pode ser apenas um elemento, que juntamente com outros elementos, contribui para a taxa de acidentes. As curvas em rodovias são uma das mais complexas características das rodovias. Os elementos ou aspectos das curvas apresentados na Tabela 3 são todos potenciais candidatos para o estudo da relação do projeto geométrico e a segurança.

O estudo realizado por GLENNON et al. em 1983 (apud GLENNON 1987) comparou acidentes em 3304 segmentos de curvas em rodovias com duas faixas, com 253 segmentos de tangentes. Cada segmento analisado tinha o comprimento de 0,965 km e foi selecionado cuidadosamente para minimizar a variação associada com a proximidade de interseções e pontes em relação às curvas. As conclusões resultantes deste estudo foram:

1. a taxa média de acidentes em curvas é cerca de três vezes a taxa média de acidentes em tangentes;

2. a taxa média de acidentes onde somente um veículo está envolvido e este sai fora da pista em curvas é cerca de quatro vezes a taxa média destes acidentes em tangentes. 
Embora estas conclusões sejam gerais e podem variar consideravelmente com o grau e comprimento da curva, elas mostram que as curvas são substancialmente mais perigosas do que as tangentes e que acidentes com um único veículo que sai da pista são um aspecto predominante das curvas.

Tabela 3 - Elementos da Curva que São Potenciais Candidatos Para o Estudo da Relação do Projeto Geométrico e a Segurança.

\begin{tabular}{|c|c|}
\hline Elemento & Descrição \\
\hline \multirow[t]{6}{*}{ Alinhamento Horizontal } & raio de curvatura \\
\hline & comprimento da curva \\
\hline & superelevação do comprimento de transição \\
\hline & distribuição da superelevação entre a tangente e a curva \\
\hline & presença de comprimento de transição \\
\hline & distância de frenagem da curva \\
\hline \multirow[t]{6}{*}{ Seção Transversal } & taxa de superelevação \\
\hline & largura da pista \\
\hline & largura do acostamento \\
\hline & inclinação do acostamento \\
\hline & inclinação da área adjacente ao acostamento \\
\hline & largura da área livre \\
\hline \multirow[t]{3}{*}{ Alinhamento Vertical } & distância de frenagem na aproximação \\
\hline & presença e comprimento das rampas adjacentes \\
\hline & presença e comprimento das curvas verticais adjacentes \\
\hline \multirow[t]{6}{*}{ Outros } & distância entre curvas adjacentes \\
\hline & distância da interseção mais próxima \\
\hline & presença e largura de pontes adjacentes \\
\hline & nível de atrito do pavimento \\
\hline & presença e tipo de dispositivos de controle de tráfego \\
\hline & tipo do material do acostamento \\
\hline
\end{tabular}

Fonte: GLENNON (1987) página 49

RABBANI et al (1994) analisaram a influência dos elementos da geometria (curvatura horizontal, curvatura vertical, largura de pista, interseções, número de 
pontes) com os acidentes na BR 101/PB no período de 1989 a 1991. Foi estabelecida a relação entre os acidentes e os parâmetros geométricos (sendo que estes valores foram retirados dos projetos de engenharia da rodovia) através de uma análise de regressão linear e constatou-se que a curvatura horizontal e vertical têm uma influência maior do que os demais parâmetros no número de acidentes e que a curvatura horizontal tem um maior efeito.

\subsubsection{RAMPAS}

A velocidade de operação é influenciada pelas características do alinhamento vertical. A variação da velocidade pode se tornar significante para caminhões e ônibus principalmente em rampas ascendentes (ROTACH 1960 apud CHOUEIRI et al. 1994). Em rampas descendentes longas com inclinação elevada, os freios podem não funcionar adequadamente quando os caminhões pesados viajam a altas velocidades. Para veículos de passageiros, as rampas também produzem variações na velocidade, mas não tão pronunciadas quanto às dos caminhões. Pode-se concluir que o aumento das rampas e o aumento da não homogeneidade do tráfego pode ocasionar um aumento do risco de acidentes (CHOUEIRI et al. 1994).

KREBS e KLOECKNER (1977) apud CHOUEIRI et al. (1994) analisaram dados de acidentes em rodovias com duas faixas de tráfego na Alemanha e concluíram que a taxa de acidentes apresenta um ligeiro aumento para rampas com cerca de $6 \%$. Para rampas maiores que $6 \%$, um aumento acentuado na taxa de acidentes é notado. Estudos realizados por CHOUERI et al. (1987) apud CHOUERI et al. (1994) indicaram que rampas com até 5\% não têm um efeito particular na taxa de acidentes.

HIERSHE et al. (1984) apud CHOUERI (1994) analisaram a relação entre a taxa de acidentes e o gradiente para projetos realizados de acordo com as normas alemãs. Eles chegaram às seguintes conclusões: 
- rampas longitudinais entre 0 e $\pm 2 \%$ apresentam os resultados mais favoráveis. Com o aumento das rampas ascendentes, a taxa de acidentes aumenta gradualmente ( a função entre a taxa de acidentes e a inclinação das rampas aproxima-se de uma reta), enquanto que com o aumento das rampas descendentes, o risco de estar envolvido em um acidente aumenta exponencialmente (a função entre a taxa de acidentes e a inclinação das rampas aproxima-se de uma exponencial) ;

ST JOHN \& HARWOOD (1991) estudaram os efeitos da implementação de terceira faixa em rampas ascendentes sobre a segurança em estradas considerando a composição de tráfego e a variação na velocidades de operação. A análise dos resultados mostrou primeiramente que o benefício da implementação da terceira faixa em rampas ascendentes com inclinação de $+2 \%$ pode ser praticamente inexistente e que existe uma pequena necessidade de se implementar a terceira faixa no início da rampas íngremes ( por exemplo nos primeiros $762 \mathrm{~m}$ de uma rampa de 4\% e nos primeiros 549 m de uma rampa de 6 \% ) pois poucos caminhões estarão com velocidades inferiores a 36,2 km/h. Além disso, os benefícios potenciais na segurança com a implementação da terceira faixa aparentam aumentar com a inclinação, comprimento da rampa e porcentagem de caminhões.

\subsubsection{CURVAS VERTICAIS}

URBANIK II et al. (1989) estudaram a influência na segurança devido à distância de visibilidade limitada em curvas verticais convexas. Duas bases de dados consistindo de 222 segmentos de estudo em rodovias com duas faixas de tráfego de aproximadamente 1,609 km de comprimento representando quase 1500 acidentes foram reunidas para avaliar o efeito da distância de frenagem ao longo de curvas verticais convexas nos acidentes. Os principais resultados desta pesquisa foram: 
- a relação entre a distância de visibilidade existente em curvas verticais convexas em rodovias com duas faixas de tráfego e acidentes é difícil de ser quantificada mesmo com um grande banco de dados;

- o modelo de projeto da distância frenagem da AASHTO não é um bom indicador da taxa de acidentes nas rodovias com duas faixas de tráfego do Texas.

- em interseções dentro de curvas verticais convexas com limitada distância de visibilidade, existe um aumento estatisticamente significante na taxa de acidentes;

- $\quad$ pode-se inferir que outras condições geométricas dentro das seções com limitada distância de visibilidade podem também causar um aumento na taxa de acidentes. Um exemplo pode ser uma curva horizontal fechada escondida pela curva vertical convexa.

- o aumento da taxa de acidentes devido a interseções com limitada distância de visibilidade em seções de curvas verticais convexas é mais pronunciado em rodovias com altos volumes de tráfego.

\subsubsection{INTERSEÇÕES}

Em rodovias com duas faixas de tráfego, as interseções são os locais mais prováveis de terem a maior concentração de acidentes juntamente com as pontes e curvas horizontais (BRINKMAN e SMITH 1984 apud TRB 1987). De acordo com o Conselho Nacional de Segurança dos Estados Unidos, 56 por cento de todos os acidentes nas vias urbanas e 32 por cento de todos os acidentes em vias rurais ocorrem em interseções (NATIONAL SAFETY COUNCIL 1985 apud TRB 1987).

As melhorias nas interseções incluem mudanças nos elementos físicos da rodovias que se interceptam e medidas operacionais para controle do tráfego. Estas melhorias geralmente concentram-se em reduzir os conflitos e melhorar as decisões tomadas pelos motoristas. É também importante reduzir a velocidade de aproximação e melhorar a resistência ao escorregamento. 
Modelar os efeitos de parâmetros específicos é difícil, devido ao grande número de características físicas e operacionais que afetam a segurança nas rodovias em interseções. Embora as relações para prever os efeitos de melhorias específicas em interseções não estejam geralmente disponíveis, algumas informações são utilizadas pelos projetistas visando remediar as deficiências destes locais perigosos. Um resumo destas informações é apresentado a seguir (TRB 1987):

1. número de ramos

2. ângulo da interseção

3. número de faixas

4. distância de visibilidade

5. alinhamento

6. faixas auxiliares

7. canalização

8. atrito pavimento-pneu

9. raio de giro

10. iluminação fixa

11. largura da faixa e do acostamento

12. indicação do direito de passagem

13. velocidade de aproximação

14. operação em uma direção

Um fator determinante da segurança em rodovias com duas faixas de tráfego é o número, tipo, e layout dos pontos de acesso. Estudos têm demonstrado que o controle total do acesso é um dos principais fatores na redução de acidentes, e controle parcial dos acessos é moderadamente efetivo (GWYNN 1966; BOX \& ASSOCIATES 1970, STOVER et al.. 1970; ROY JORGENSEN ASSSOCIATES Inc. 1978; OECD 1986 apud LI et al. 1994). Desde que o acesso completamente controlado não é prático em grande parte das rodovias com duas faixas de tráfego, medidas eficazes necessitam de um conhecimento íntimo da relação entre os acidentes e várias dimensões do acesso. (LI et al. 1994). Este é um dos grandes problemas existentes nas rodovias brasileiras, onde acessos que ligam as estradas de fazendas com as rodovias, 
principalmente nas regiões agrícolas, são normalmente construídos em locais perigosos sem qualquer projeto ou medidas de segurança. Além disso, a situação torna-se mais crítica, pois nestes pontos é comum trafegarem veículos combinados longos e extra pesados que são lentos e precisam de distâncias e tempos maiores para realizarem as manobras.

DART \& MANN (1970) apud LI et al. (1994) encontraram resultados que mostram que a taxa de acidentes aumenta com o número de conflitos no tráfego por milha (Figura 2). Conflitos de tráfego são definidos, neste caso, como sendo o número total de pontos de acesso de tráfego em ambos os lados por milha de seção de rodovia e incluem somente interseções de rodovias secundárias e acessos principais a propriedades privadas ao longo da rodovia. Os resultados do estudo de DART \& MANN (1970) têm sido amplamente adotados na área de gerenciamento de acessos, incluindo o manual da AASHTO.

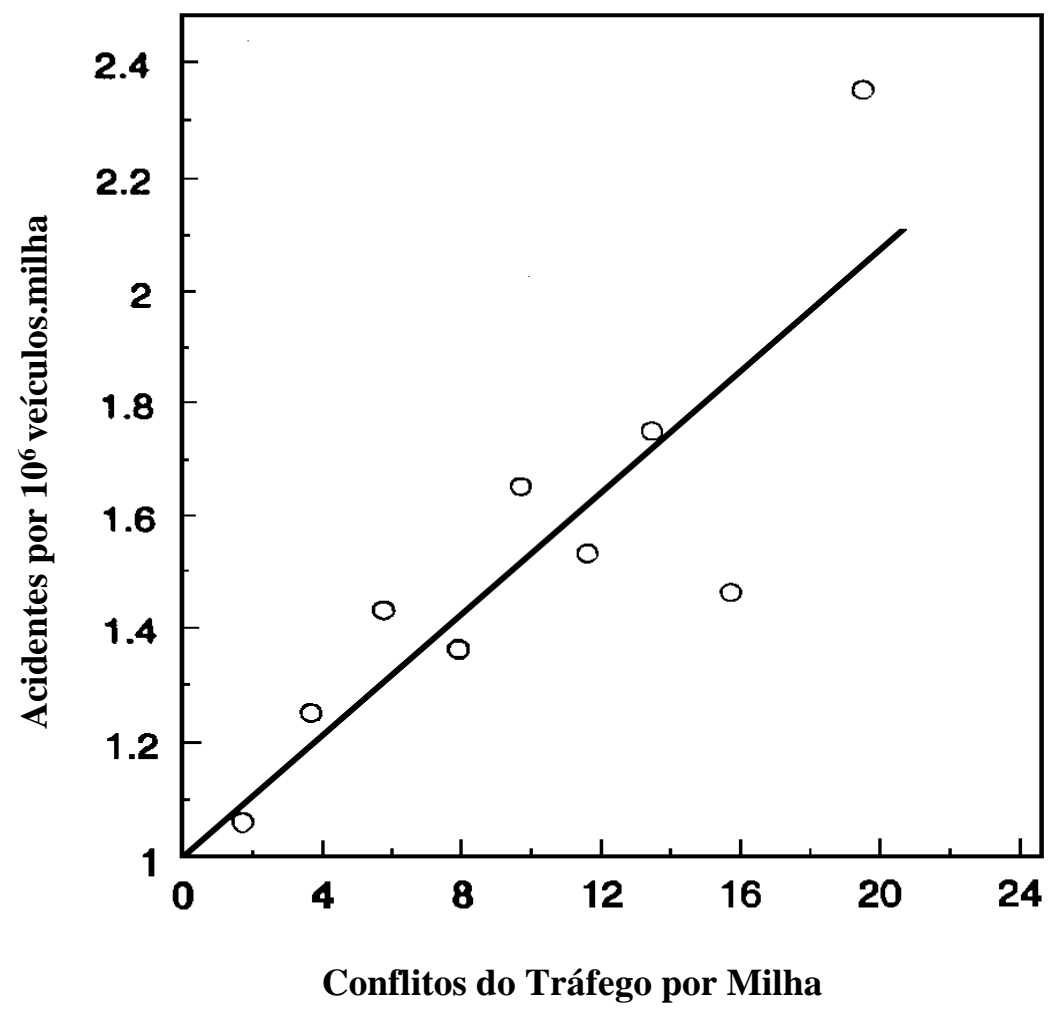

Figura 2 - Taxa de Acidentes versus Conflito de Tráfego 
Fonte: DART \& MANN (1970) apud LI et al. (1994) página 1013

O estudo realizado por LI et al. (1994) buscou examinar o impacto na segurança devido ao tipo de acesso, volume do tráfego, e a geometria de rodovias com duas faixas de tráfego de 1988 a 1990. Quatro tipos de acessos foram utilizados na análise: (i) interseções de rodovias públicas não sinalizadas; (ii) acesso comercial (incluindo o acesso industrial); (iii) acesso privado (incluindo residencial e agrícola); (iv) áreas de descanso. A técnica de regressão linear múltipla foi aplicada para desenvolver os modelos que descrevem os efeitos combinados do acesso, tráfego e características da rodovia sobre a segurança. As seguintes observações podem ser deduzidas dos resultados das análises estatísticas:

- todos os tipos de acessos estão significantemente correlacionados com a ocorrência de acidentes em rodovias com duas faixas de tráfego. Como era esperado, as interseções públicas revelam ter um importante efeito nas medidas de todos os acidentes (uma interseção pública é equivalente a 10 acessos privados);

- o limite de velocidade tem um importante efeito na relação entre a densidade de acessos comerciais e a taxa de acidentes. O impacto dos acessos comerciais na taxa de acidentes aparenta intensificar com o aumento do limite da velocidade.

- a curvatura horizontal (medida pelo grau de curvatura médio) tem um importante efeito na relação entre a ocorrência de acidentes e a densidade dos acessos privados e áreas de descanso. O impacto do acesso privado e das áreas de descanso na taxa de acidentes aparenta aumentar com o aumento do grau de curvatura médio;

- Rampa, curvatura horizontal e a freqüência da mudança da direção da curva, contribuem positivamente para a ocorrência de acidentes, enquanto a inclinação transversal está negativamente correlacionada com os acidentes. 


\subsubsection{CONSISTÊNCIA DAS RODOVIAS.}

As relações de segurança com o projeto geométrico apresentadas anteriormente mostram os fatores presentes no meio ambiente da rodovia que possivelmente contribuem para o aumento da insegurança. Para ilustrar esta insegurança podem-se citar interseções com alto volume de tráfego, curvas horizontais depois de longos trechos retos e curvas horizontais contíguas para o mesmo lado, na qual uma curva suave precede uma curva fechada. Tais situações violam a expectativa do motorista com relação à rodovia. O motorista que não está familiarizado com a rodovia ou está desatento, presume que o trecho seguinte será tão suave quanto o anterior e é surpreendido pela aparição repentina de um perigo em potencial. A resposta pode ser incerta e devagar, levando possivelmente a manobras impróprias e aumento do potencial de acidentes (TRB, 1987).

Em geral, o grau de perigo inerente a uma característica específica, tais como pontes estreitas, curvas fechadas, pistas sem acostamento, não depende somente dessa característica, mas também da natureza próxima ao ambiente da rodovia. Técnicas úteis para eliminar estes pontos de inconsistências ou compensar seus efeitos adversos incluem (TRB, 1987):

- provisão de transições geométricas graduais apropriadas às velocidade de operação do veículo;

- melhorar a distância de visibilidade para detecção rápida da presença de características críticas

- provisão de inclinação suave das áreas adjacentes à rodovia com poucos obstáculos nos locais críticos; e

- instalação de controle de tráfego apropriado para a situação.

SMITH \& LAMM (1994) estudaram a coordenação do alinhamento vertical e horizontal com relação à estética das rodovias. Para eles, duas considerações importantes no projeto da rodovia são a velocidade de projeto e a distância de 
visibilidade. Isto depende das características do alinhamento vertical e horizontal da rodovia. Alinhamentos verticais e horizontais favoráveis permitem velocidades de projeto mais altas e distância de visibilidade estendidas, resultando no aumento da segurança do motorista. Embora se espere intuitivamente que aumente a freqüência e severidade dos acidentes devido a certas combinações não favoráveis do alinhamento vertical e horizontal, não se sabe muito a respeito de tais combinações de alinhamentos com alta freqüência de acidentes.

Os problemas de percepção visual gerados pela superposição de curvas verticais e horizontais podem ser visualizados na Figura 3, a qual mostra como as curvas verticais côncavas e convexas mudam a visão tridimensional da rodovia quando superpostas com curvas horizontais. As conseqüências da superposição são apresentadas na Figura 4 que mostra a geometria, a localização dos acidentes e as causas dos acidentes para uma superposição típica de curvas horizontais e curvas verticais côncavas e convexas.
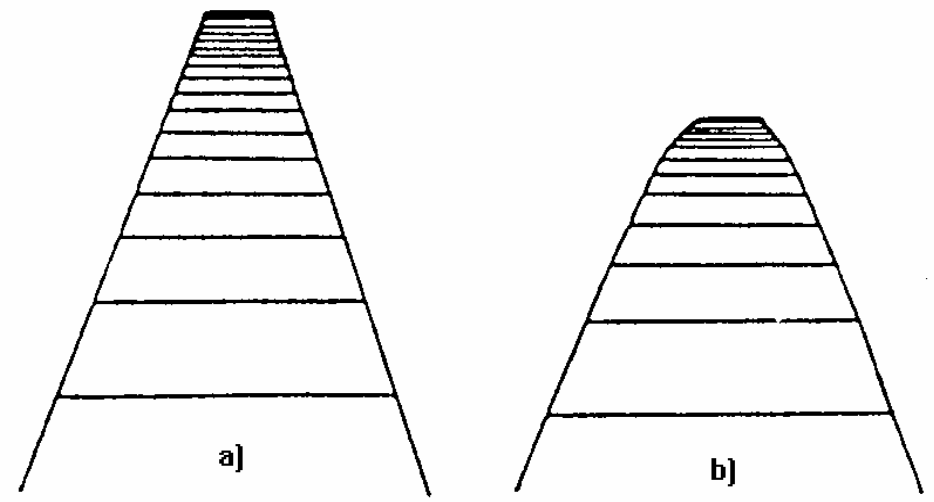

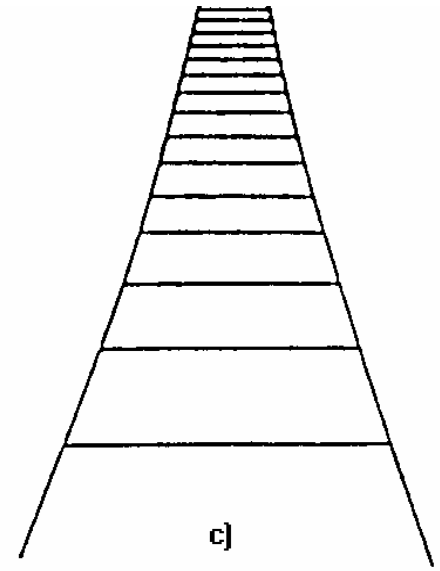



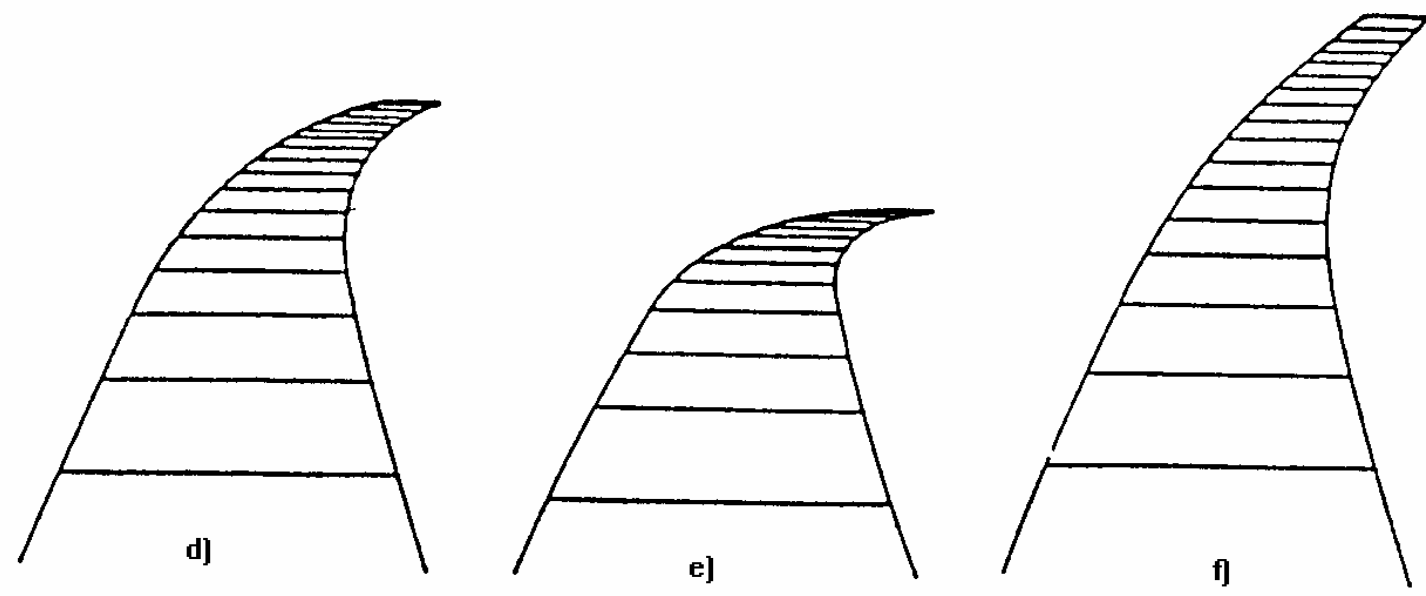

Figura 3 - Diferentes Visões Tridimensionais com a Superposição de Curvas Verticais e Horizontais: (a) Tangente Horizontal; (b) Tangente Horizontal com Superposição de uma Curva Vertical Convexa; (c) Tangente Horizontal com Superposição de uma Curva Vertical Côncava; (d) Curva Horizontal; (e) Curva Horizontal com Superposição de uma Curva Vertical Convexa; (f) Curva Horizontal com Superposição de uma Curva Vertical Côncava;

Fonte : OSTERLOH, H. (1983) e LAMM, R (1982) apud SMITH \& LAMM (1994) pág 82 

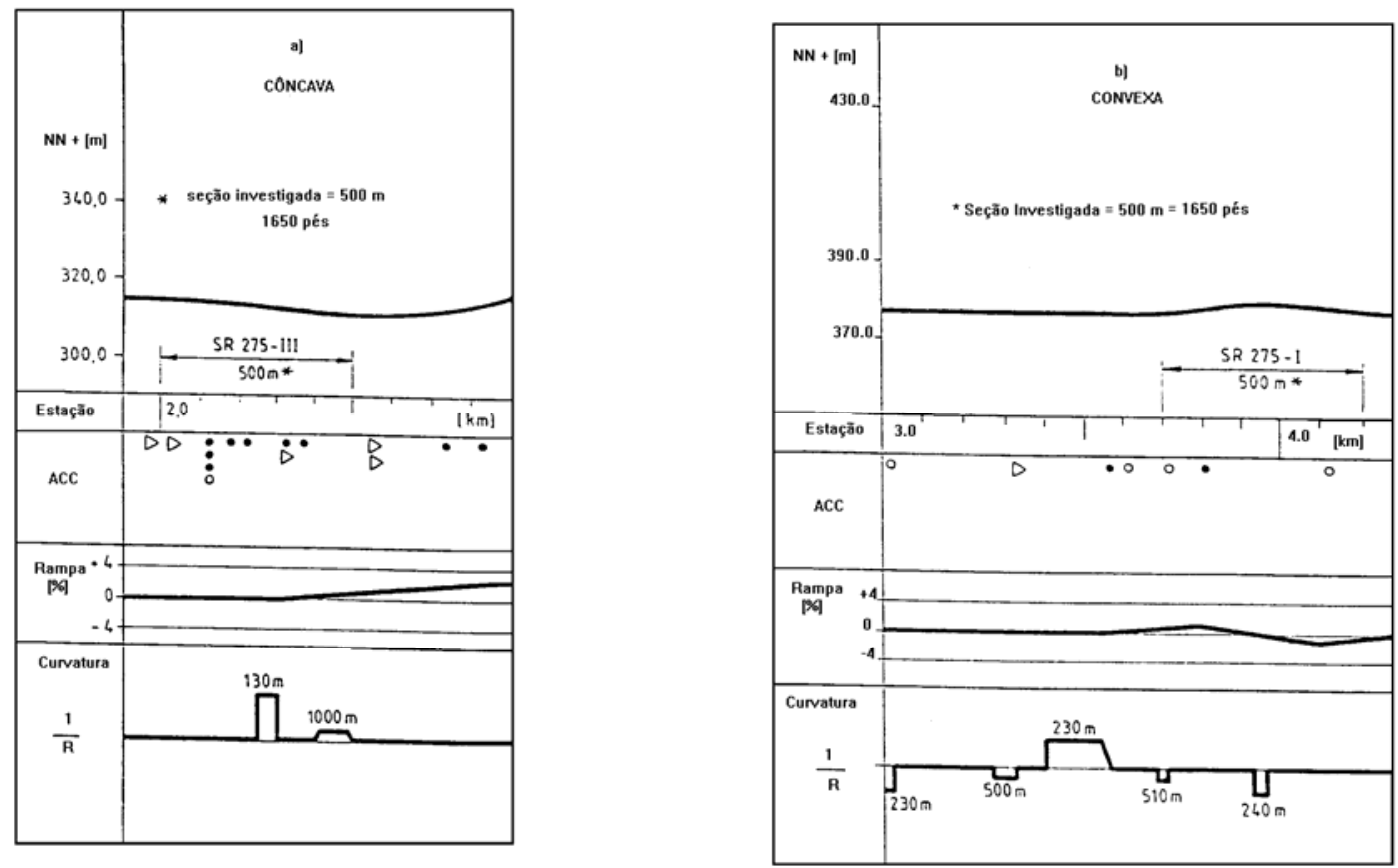

ACC - Causas do Acidente:

- velocidade excessiva

$\square$ interseção

O colisão frontal e ultrapassagem

$\kappa$ outras

Figura 4 - Influência na Situação dos Acidentes (ACC) pela Superposição de Curvas Horizontais e Verticais : (a) Côncava e (b) Convexa

FONTE: LAMM, R (1982) apud SMITH \& LAMM (1994) pág 83

LAMM et al. (1988) apresentaram um método para avaliar a consistência dos elementos geométricos em rodovias de duas faixas no Estado de Nova York. Nesta pesquisa foram avaliados os impactos do grau de curvatura, comprimento das rampas, taxa de superelevação, largura da faixa e do acostamento, distância de visibilidade, gradiente, velocidade recomendada e volume de tráfego na taxa de acidentes e na velocidade de operação. O estudo demonstrou que os parâmetros que melhor explicaram a variabilidade na velocidade de operação e na taxa de acidentes são o grau de curvatura e a velocidade recomendada. A relação entre estes 
parâmetros e a taxa de acidentes é mostrada na Tabela 4. Estas relações entre a geometria, velocidade de operação e acidentes em conjunto com o sistema de classificação formam a base para a metodologia de projeto sugerida pelos autores.

Tabela 4 - Equações para Prever as Taxa de Acidentes para Diferentes Larguras de Faixa

\begin{tabular}{|l|l|}
\hline \multicolumn{1}{|c|}{ Largura da Faixa } & \multicolumn{1}{c|}{ Equação } \\
\hline Todas as larguras & ACCR $=-0,880+1,410 * \mathrm{DC}$ \\
\hline $3 \mathrm{~m}$ & $\mathrm{ACCR}=-1.023+1,513 * \mathrm{DC}$ \\
\hline $3,3 \mathrm{~m}$ & $\mathrm{ACCR}=-0,257+1,375 * \mathrm{DC}$ \\
\hline $3,6 \mathrm{~m}$ & $\mathrm{ACCR}=-0,543+1,075 * \mathrm{DC}$ \\
\hline
\end{tabular}

ACCR - taxa de acidentes - acidentes $/ 10^{6}$ veículos.milha

DC - grau de curvatura - $\%$ 30,48 m

Fonte: LAMM et al. (1988) página 112

No Brasil, SANTOS (1992) analisou vários métodos para avaliação da consistência dos elementos geométricos de uma rodovia, dentre eles: o método de LEISCH \& LEISCH, LAMM et al., normas suíças e normas alemãs. Para comparação das medidas de análise e classificação da consistência da geometria de rodovias foram utilizados dados da geometria e da operação de veículos provenientes de um trecho de $6 \mathrm{~km}$ pertencente à rodovia "EP12 Goioerê - Formosa d'Oeste" do Estado do Paraná. 


\subsection{SISTEMA DE INFORMAÇÃO GEOGRÁFICA}

Um Sistema de Informação Geográfica (SIG) é um sistema de gerenciamento de banco de dados computadorizado capaz de coletar, armazenar, analisar, e mostrar os dados com referência a um sistema espacial (SIMKOWITZ, 1989). Também pode ser definido como sendo uma combinação complexa de "hardware, software, dados e organizações e arranjos institucionais para coletar, armazenar, analisar e disseminar informações a respeito de áreas da Terra (STOKES \& MARUCCI, 1995).

O sistema SIG já é utilizado por milhares de organizações privadas e públicas em todo o mundo, para uma grande variedade de aplicações, e no trabalho de dúzias de diferentes disciplinas e profissões. O campo tem crescido a uma taxa de cerca de 24 a $40 \%$ por ano e se a tendência continuar, mais de um milhão de pessoas estarão utilizando a tecnologia SIG no ano 2000 (DANGERMOND, 1992).

Considerações espaciais são fundamentais para a maioria das atividades de transportes. A coleta de dados relacionados com as rodovias envolve uma grande variedade de atividades: contagem de tráfego, inventário das placas de sinalização, medidas de resistência ao escorregamento, investigação de acidentes, registro dos projetos de construção e manutenção, inventários dos obstáculos, inspeção de pontes, monitoramento de velocidade, pesquisas da condição do pavimento, inventários do projeto geométrico e outros. Na maioria dos casos, estes vários arquivos de dados dentro da mesma agência de transportes não estão ainda relacionados, sendo muitas vezes duplicados e inconsistentes (SIMKOWITZ, 1989).

Os exemplos seguintes ilustram a importância da utilização de um sistema georeferenciado (SIMKOWITZ, 1989):

- a análise de acidentes necessita, além dos dados sobre os motoristas envolvidos, da correlação de um número de variáveis sobre a rodovia e o ambiente, tais 
como: condição do pavimento, geometria da rodovia, condições do clima, volume do tráfego, sinalização e iluminação. Uma maneira fácil de se associar estas variáveis é através de um sistema referenciado geograficamente comum.

- um sistema de gerenciamento de pavimento registra o histórico da construção e manutenção bem como as condições dos segmentos das rodovias e auxilia a tomada de decisões ao selecionar o tratamento apropriado para as deficiências. Tipicamente, a condição e tratamento da rodovia são apresentados em uma forma tabular e o engenheiro tem que transferir esta informação para o mapa. Uma interface com o mapa e dados geocodificados facilitará o processo de entrada de dados, desenvolvimento e programação dos projetos. Também pode ser utilizado para produzir relatórios estatísticos e saídas gráficas indicando a condição da rede.

Várias instituições nos Estados Unidos estão utilizando o SIG para gerenciar os seus dados. O Office of Policy Development (HPP-1) foi o primeiro escritório dentro do Federal Highway Administration (FHWA) que utilizou o SIG para análises dos planos de ação de rodovias. O banco de dados contém mais de 45000 conexões e representa mais de $595000 \mathrm{~km}$ de rodovias. Os atributos de cada conexão na rede incluem: a classificação funcional do FHWA, a classificação administrativa federal, número da rota, comprimento, tipo de controle de acesso, número de faixas, tipo de pavimento etc. Outros bancos de dados do SIG incluem os volumes de tráfego interestaduais, fronteiras estatuais, aeroportos, instalações militares e pontes. (STOKES \& MARUCCI, 1995).

O Departamento Estadual de Transportes de Wiscosin, EUA, um reconhecido líder no desenvolvimento e integração do SIG-T (Sistema de Informações Geográficas específico para transportes), tem um SIG baseado no sistema de gerenciamento de pavimento que é operacional e está sendo utilizado por vários administradores. Também pode ser utilizado para manutenção e gerenciamento de pontes com inventário e manutenção da sinalização (STOKES \& MARUCCI, 1995).

O Departamento de Transportes de Ohio, EUA, começou o desenvolvimento do seu SIG em 1980. O sistema foi projetado para localizar e mostrar os acidentes. O 
sistema utiliza as informações do Inventário da Rodovia (Road Inventory) e o Inventário da Resistência ao Escorregamento (Skid Inventoy) para calcular as taxas de acidentes e identificar as condições potencialmente perigosas da rodovia. (STOKES \& MARUCCI, 1995)

Departamento de Transportes de Kansas, EUA, estimou a viabilidade de integrar mapas digitalizados utilizando um CAD e arquivos de dados de acidentes em um SIG. O projeto piloto consiste na avaliação do nível de esforço associado com as seguintes atividades de conversão do SIG . (STOKES \& MARUCCI, 1995):

1. a importação de uma base de mapas do CAD para SIG ;

2. a união dos arquivos de dados de acidentes com interseções e não-interseções do SIG;

3. teste do protótipo resultante (por exemplo, comparando pesquisas dos dados dos acidentes com as pesquisas do SIG).

Departamento de Transportes da Virgínia, EUA, e o Conselho de Pesquisas em Transportes da Virgínia estuda a determinação da viabilidade de utilização de uma unidade móvel a velocidade de 48 a $56 \mathrm{~km} / \mathrm{h}$ para coletar dados em rodovias secundárias, principais e interestaduais, utilizando o Sistema de Posicionamento Global - GPS. O estudo é designado a responder um número de questões relacionadas com a viabilidade da utilização do GPS (SIMKOWITZ, 1989):

- a precisão dos itens da rodovia coletados

- o custo do levantamento por milha coletada nos vários tipos de rodovia

O Departamento de Transportes do Tennessee, EUA, conduziu um estudo similar. 
Existem no mercado vários softwares que auxiliam os Departamentos Governamentais na elaboração de um Sistema de Informação Geográfica para a sua cidade ou estado, dentre eles o ArcInfo, Maptitude e o TRANSCAD. O TRANSCAD é um Sistema de Informação Geográfica que auxilia profissionais e organizações a armazenar, mostrar, gerenciar e analisar dados de transportes. O TRANSCAD tem aplicações a nível internacional, nacional, regional e local, e pode ser utilizado para qualquer um ou todos os sistemas de transporte. Informações sobre redes, fluxo de carga, rotas, roteiro, transporte, análise de zonas, demanda de passageiros, e o desempenho do sistema de transporte podem ser armazenadas, mostradas e analisadas em qualquer escala espacial (CALIPER (1997)).

TRANSCAD fornece (CALIPER (1997)):

- um fácil acesso a dados de transportes e geográficos relacionados

- modelos de dados estendidos para apoiar o planejamento em transporte, logística, roteamento, pesquisas operacionais e aplicações de marketing

- ferramentas para apresentar e visualizar os dados de transportes

- uma completa caixa de ferramentas de métodos e modelos de análise de transporte

- capacidade de multimídia

Informações sobre rodovias, ferrovias e trânsito são freqüentemente armazenadas em tabelas que não contêm informações sobre a latitude e a longitude. Cada registro desta tabela é associado com uma localização particular, indicada pela identificação da rota e a distância de um ponto fixado da rota. O TRANSCAD faz mapas de dados linearmente referenciados pela conversão da quilometragem da rodovia em latitude e longitude, utilizando informações contidas em uma camada de um sistema de rotas. Esta conversão é feita automaticamente quando cada característica for mostrada, como por exemplo, quando se deseja localizar os acidentes ou a condição do pavimento (CALIPER, 1995) (Figuras 5, 6 e 7 ). 


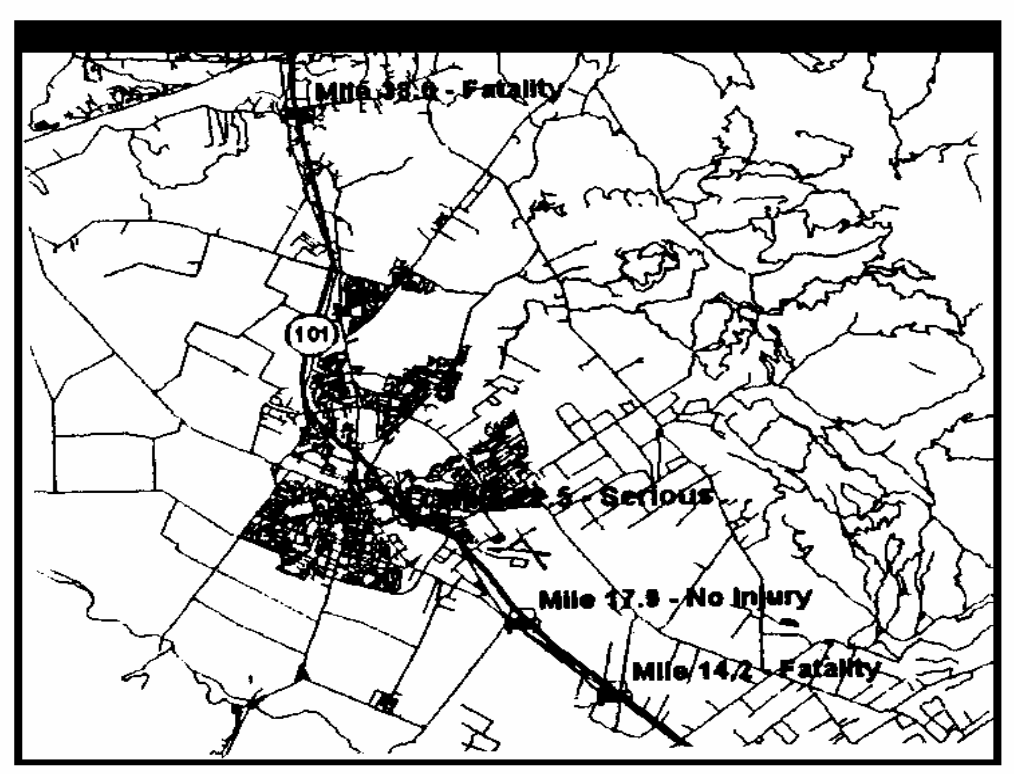

Figura 5 - Localização dos Acidentes

Fonte: CALIPER (1995) pág. 21-10

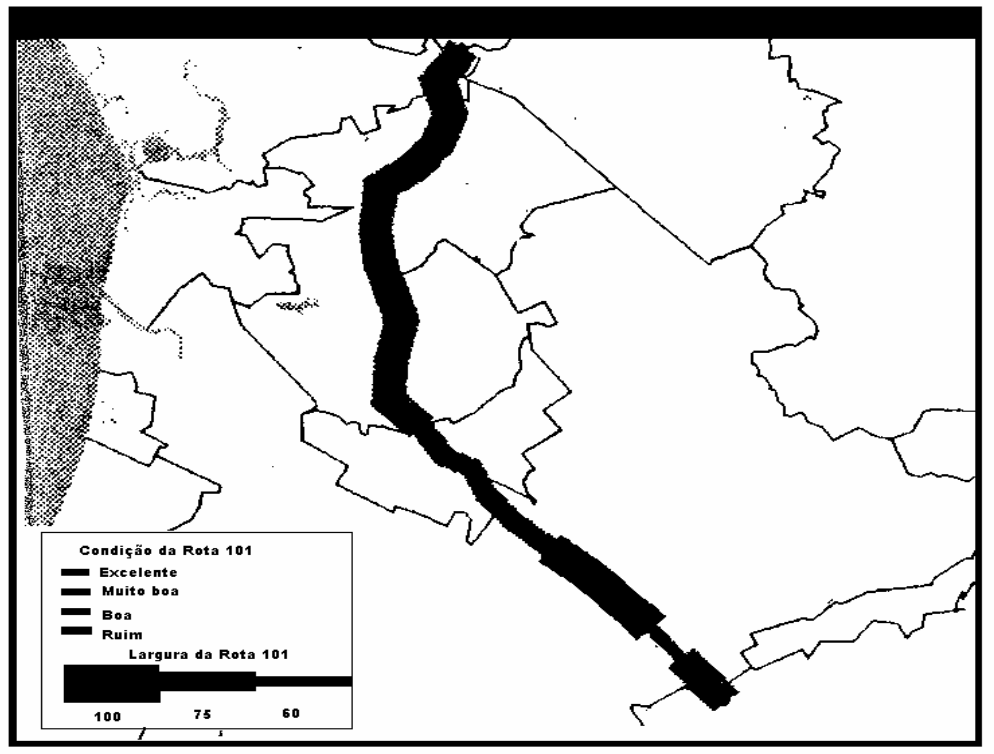

Figura 6 - Condição do Pavimento

Fonte: CALIPER (1995) pág. 21-14

Os dados sobre a rodovia também podem ser apresentados através de gráficos. 


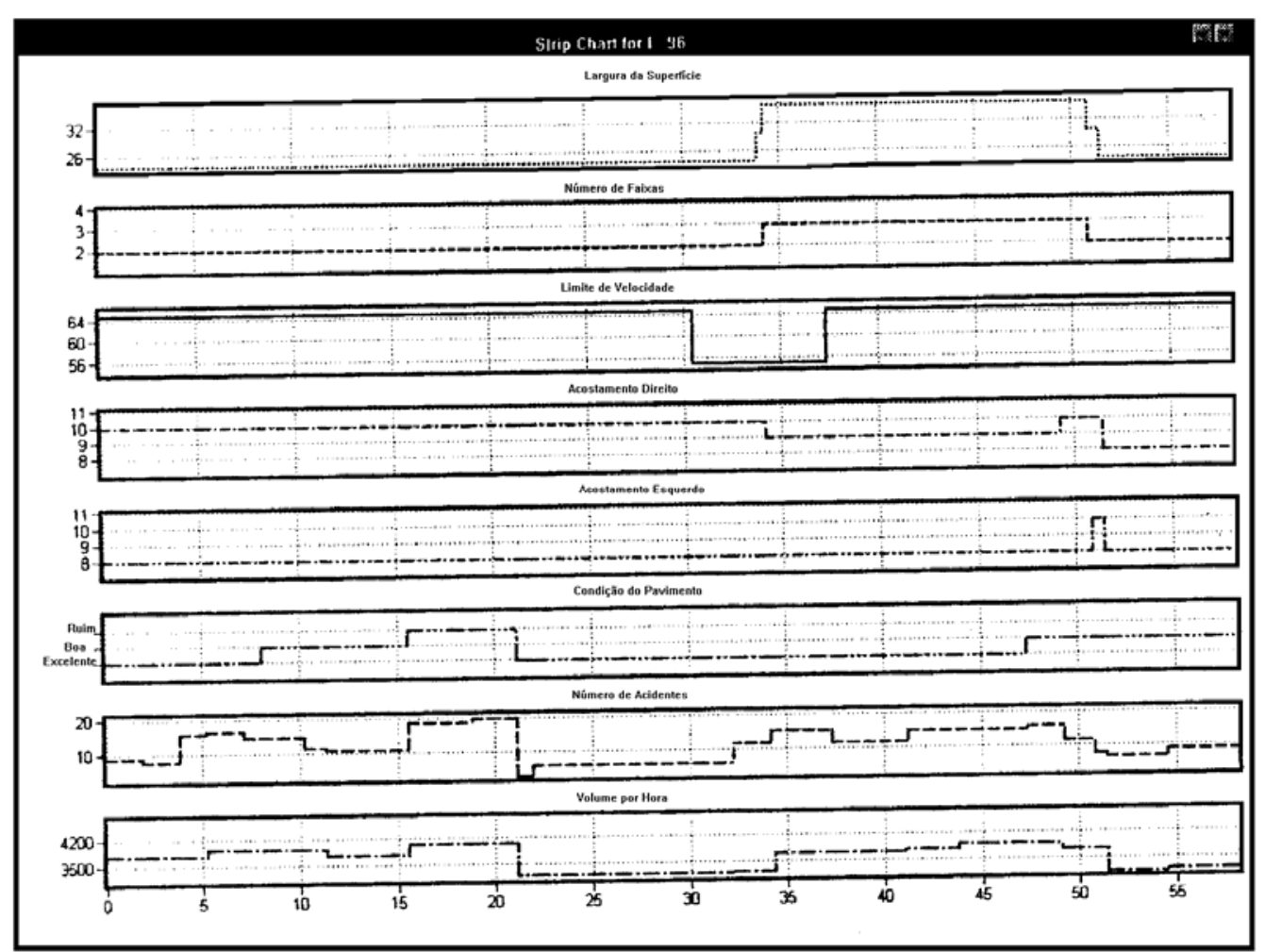

\section{Figura 7 - Gráficos dos Dados}

Fonte: CALIPER (1995) pág. 21-14

O problema inicial para a formação de um SIG é a criação de uma base de dados geográficos. Os métodos utilizados em geral para se obter dados geocodificados são (DILDINE 1988 apud SIMKOSWITZ 1989):

- utilização de dados digitais existentes;

- utilização de scanner;

- GPS;

- processamento de imagens para atualizar as características do mapa;

- fotogrametria

- digitalização

- outros; 
No item seguinte são apresentados quatro métodos de levantamento de uma base geográfica de dados de uma rodovia. A escolha do método de levantamento dos dados geográficos depende basicamente da precisão requerida, dos custos de equipamento e da equipe de trabalho, dos recursos disponíveis e das condições do local. Para a maioria dos estudos relativos às condições de desempenho operacional de uma rodovia a precisão requerida é bem menor que a precisão de levantamentos topográficos ou geodésicos. A menos de problemas de seção transversal e de drenagem, erros da ordem de 1m, tanto planimétrico como altimétrico, não interferem praticamente na análise de problemas operacionais associados ao traçado da rodovia. Como veremos, entretanto, as técnicas de medida, mesmo as cinemáticas, nos fornecem níveis de precisão muito superiores a escala métrica. 


\subsection{MÉTODOS DE LEVANTAMENTO DA BASE GEOGRÁFICA}

\subsubsection{MÉTODO CONVENCIONAL}

A medida ótica das distâncias (ODM - Optical Distance Measurement) com teodolitos, níveis e réguas tornou-se obsoleta com o advento do EDM (Eletronic Distance Measurement - Medida Eletrônica da distância). O equipamento EDM revolucionou completamente todos os procedimentos de levantamento, resultando em uma mudança de ênfases e técnicas. Agora, as distâncias podem ser medidas rapidamente com grande precisão, sem considerar as condições do terreno. Os equipamentos de EDM modernos contêm algoritmos que reduzem a distância inclinada às distâncias verticais e horizontais equivalentes.

As inovações na tecnologia e a descoberta do microchip transformaram os equipamentos EDM em unidades menores, que podem ser montadas em um teodolito, representando uma estação total. Para grande parte dos levantamentos da engenharia, as estações total são agora o equipamento padrão.

A estação total (Figura 8) é um instrumento completamente integrado, que captura todos os dados espaciais necessários para a determinação de coordenadas tridimensionais. Os ângulos e as distâncias são mostrados através de um sistema digital e podem ser armazenadas. Elas são ajustadas através de dois compensadores que melhoram a precisão do ângulo lido. Sensores dentro do instrumento monitoram as medidas dos eixos, calculando o erro e aplicando as correções às observações (SCHOFIELD, 1993). 
O desenvolvimento da tecnologia da estação total durante os últimos 10 anos alcançou um estágio onde o mínimo de esforço é necessário para coletar rapidamente informações precisas de coordenadas. Tradicionalmente duas pessoas têm sido necessárias para realizar tais levantamentos: uma utilizando o instrumento e outra movimentando o prisma para os pontos desejados. Recentes avanços na indústria da estação total reduziram a equipe de levantamento para uma pessoa por empregar equipamentos motorizados e conexão via rádio (GERDAN, 1992).

O desenvolvimento do EDM tem produzido mudanças fundamentais nos procedimentos de levantamento, como por exemplo (SCHOFIELD, 1993):

- a inclusão de um número maior de distâncias medidas na triangulação , tornou a triangulação clássica obsoleta. Isto resulta em controle maior sobre o erro de escala;

- controle fotogramétrico sobre grandes áreas por coordenadas polares a partir de uma única linha base;

- determinação de coordenadas de posições marítimas;

- monitoramento da deformação com precisão sub-milimétrica utilizando EDM de alta precisão, tais como o Com-Rad Geomensor CR234, cuja precisão é $\pm 0,1 \mathrm{~mm}$ $\pm 0,1 \mathrm{~mm} / \mathrm{km}$.

A precisão e a distância medida com estes instrumentos tem evoluído muito. As distâncias entre pontos medidos aumentaram para 2,5 km utilizando-se um único prisma em condições médias e para 3,5 km em condições excelentes. As distâncias medidas aumentaram para $7 \mathrm{~km}$ com a utilização de uma série de prismas. As precisões lineares variam de $\pm(3 \mathrm{~mm}+3 \mathrm{~mm} / \mathrm{km})$ a $\pm(1 \mathrm{~mm} \pm 1 \mathrm{~mm} / \mathrm{km})$, com precisão angular variando de 5”a 1”. 


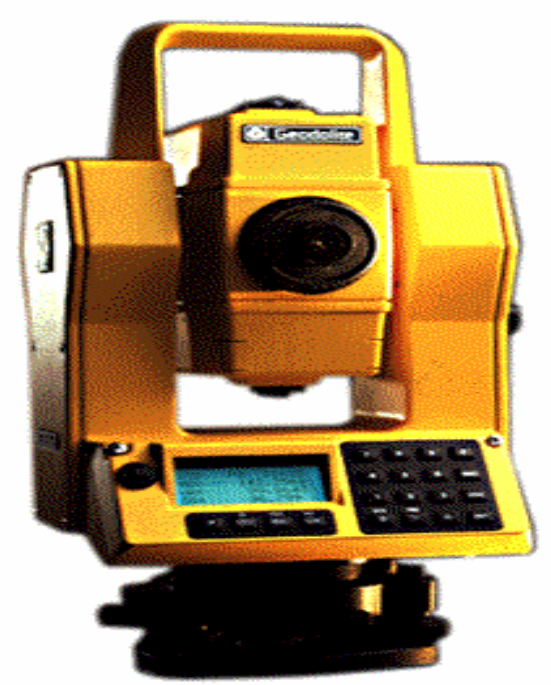

Figura 8 - Estação Total

Fonte: GEOTRONICS (1997)

\subsubsection{FOTOGRAMETRIA}

Neste método é utilizado uma aeronave equipado com uma câmera fotográfica aérea com um sistema de alta resolução e mínima distorção para obter fotos dos locais desejados, como por exemplo uma rodovia (Figura 9).

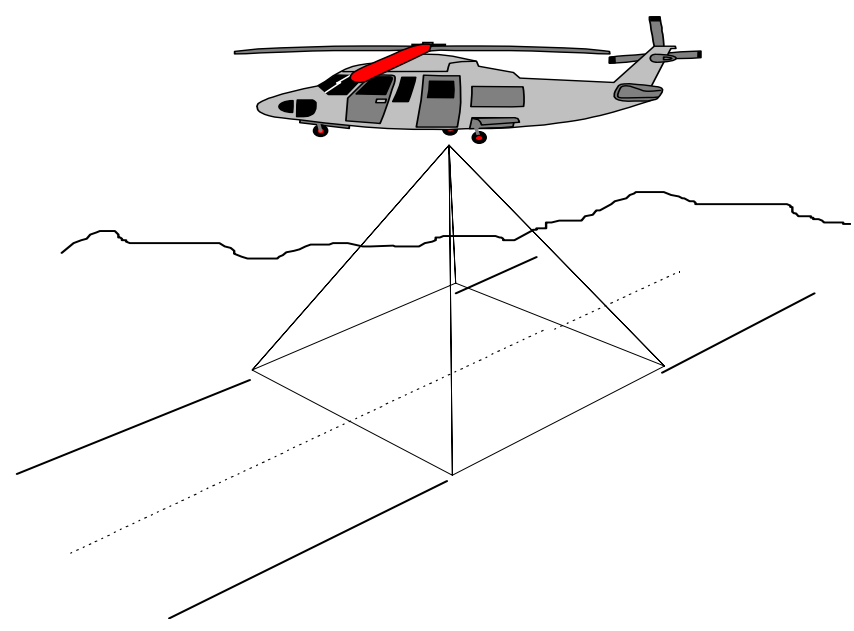

Figura 9 - Foto Aérea de uma Rodovia 
Geralmente, pensa-se que a fotogrametria é a ciência das medidas para os inventários da superfície da Terra. Entretanto, a fotogrametria pode ser usada em diferentes campos, como por exemplo (SEGANTINE, 1988):

- construção de estradas (reconhecimento para anteprojeto, projeto de drenagem, localização de jazidas etc.);

- construção de barragens (escolha do eixo da barragem etc);

- construção de portos e canais;

- geologia (fotointerpretação, drenagem, relevo etc).

Um aspecto importante para a operação de mapeamento fotogramétrico e análise métrica das fotos é o estabelecimento de um bom sistema de controle. O controle fotogramétrico consiste em pontos com coordenadas conhecidas em relação a um sistema de coordenadas, que podem ser facilmente identificados na fotografia. $\mathrm{O}$ controle pode ser classificado em (SEGANTINE, 1988):

- horizontal - a posição do ponto no espaço é conhecida em relação a um plano de referência horizontal;

- vertical - a posição do ponto no espaço é conhecida em relação a um plano de referência vertical.

Os principais problemas inerentes à fotogrametria são (SEGANTINE, 1988):

- cada exposição deveria estar alinhado na posição ideal e na altitude previamente determinada;

- o eixo ótico da lente deveria ser feito exatamente na vertical no momento da exposição (para as fotografias verticais), ou o ângulo de desvio a partir da vertical deveria ser calculado;

- a câmera deveria ser orientada, no momento da exposição, como foi planejado com antecedência; 
- não deveria haver nenhum movimento do avião com relação à terra no momento da exposição;

- as condições atmosféricas deveriam ser perfeitas no momento da exposição (sem a presença de nuvens e névoa, de modo a reduzir a refração atmosférica).

Departamento de Transportes da Califórnia desenvolveu um programa de compilação de mapas em três dimensões utilizando fotos aéreas. Um exemplo do trabalho desenvolvido é mostrado na Figura 10. Na Figura 11 é mostrado o mapa tridimensional obtido através da foto aérea (LAUNEN, 1993).

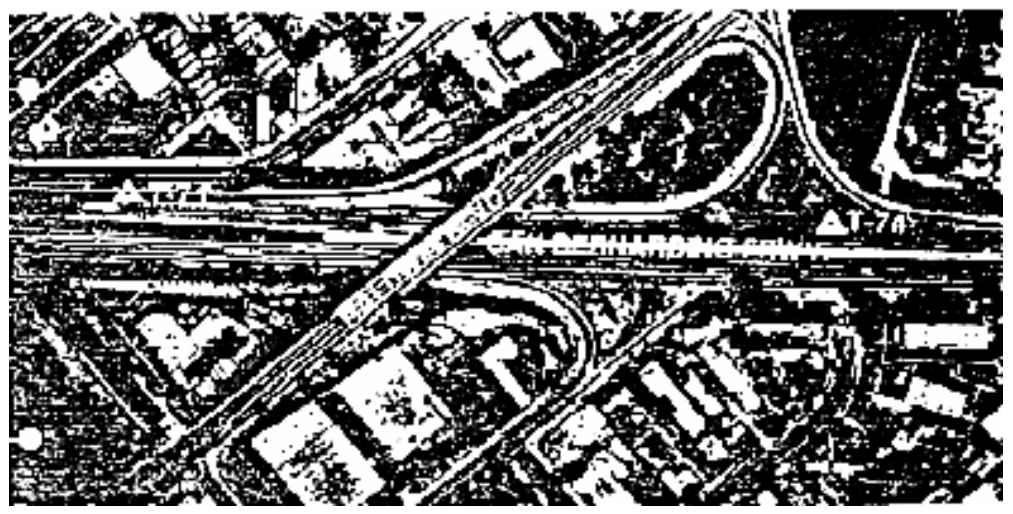

Figura 10 - Freeway San Bernardino

Fonte: (LAUNEN, 1993) página 47

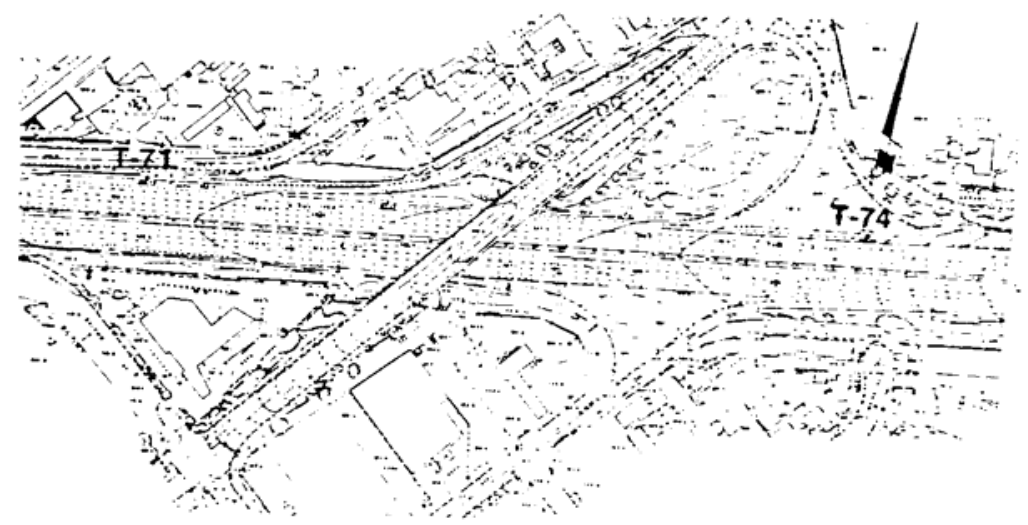

Figura 11 - Mapeamento Obtido Através da Foto Aérea da Freeway San Bernardino

Fonte: (LAUNEN, 1993) página 48 


\subsubsection{SISTEMA INERCIAL}

O sistema de levantamento inercial (Inertial Surveying System - ISS) fornece a posição tridimensional de um ponto em relação a um referencial sem ser afetado pela refração atmosférica, sem requerer intervisibilidade entre os pontos, podendo ser operado durante o dia ou a noite em qualquer condição climática e sem limitação prática da velocidade do veículo em que está instalado.

O sistema consiste basicamente de uma plataforma inercial composta por três acelerômetros fixados em três eixos ortogonais e por três giroscópios precisos orientados similarmente (Figura 12), um computador que monitora e controla o alinhamento inicial do sistema em um sistema de coordenadas e calcula a posição relativa em tempo real, uma bateria e unidades de controle, armazenamento e apresentação dos dados de campo (SCHOFIELD, 1993).

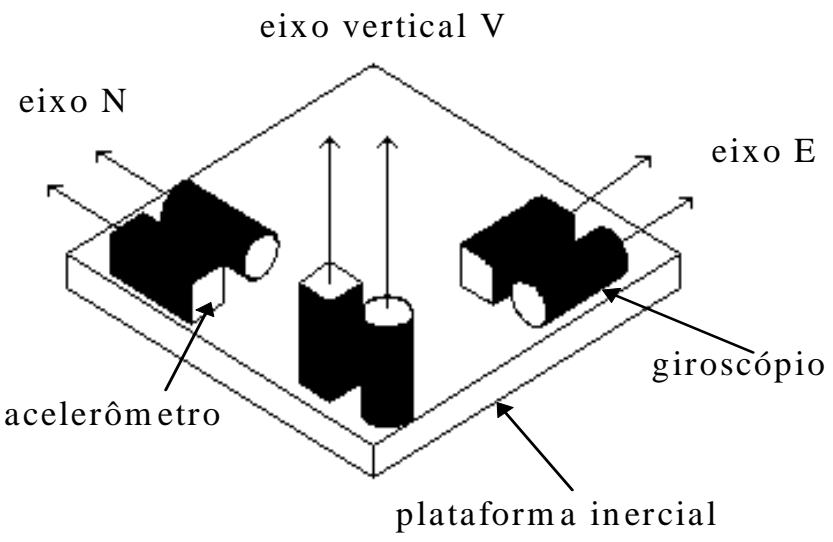

Figura 12 - Sistema Esquemático de uma Plataforma Inercial

Fonte: SCHOFIELD (1993) página 314 
Três diferentes arranjos são utilizados para orientar os eixos da plataforma (KAHMEN \& FAIG, 1988):

- plataforma estabilizada no espaço (space stabilized plataform);

- plataforma com nível local (local level plataform);

- strap down plataform.

O uso de plataformas inerciais pode fornecer posições precisas se as seguintes regras forem obedecidas (SCHOFIELD, 1993):

- deve-se dirigir em linha reta com uma velocidade uniforme

- deve-se realizar o procedimento ZUPT (zero velocity update) a cada 3-5 minutos para fornecer os sistemas de controle. Quando o veículo pára as três velocidades devem ser zero. Caso não sejam, a direção de cada acelerômetro e giroscópio é armazenada. Estes erros na velocidade são colocados em um filtro Kalman e uma nova série de relações entre os erros e o sistema é calculada para corrigir a posição do ponto e de todos os pontos anteriores

- o sistema tem que ser recalibrado a cada 5-6 horas

- pontos de coordenadas conhecidas devem ser incluídos para serem utilizados com referência a cada 1-2 horas

- o tempo de levantamento deve ser o menor possível, pois os erros do sistema aumentam com o tempo (KAHMEN \& FAIG, 1988) 


\subsubsection{GPS}

O NAVSTAR GPS (NAVigation System with Time Ranging Global Positioning System) é um sistema de rádio navegação baseado em satélites que fornece a posição tridimensional precisa, navegação e informação temporal para usuários convenientemente equipados. O sistema está disponível continuamente em uma base mundial e é independente das condições meteorológicas (JANICZEK 1980, 1984, 1986 apud SEEBER 1993).

O sistema atual consiste de 26 satélites, colocados em órbitas de cerca de 20200 km de altitude acima da superfície terrestre (Figura 13). O arranjo dos satélites foi planejado de tal forma que pelo menos quatro satélites são simultaneamente visíveis acima do horizonte em qualquer lugar da Terra, vinte quatro horas por dia.

Com a constelação completa, o segmento espacial fornece uma cobertura global com quatro a oito satélites sendo observados simultaneamente com elevação acima de $15^{\circ}$ em qualquer horário do dia. Se a elevação de corte for reduzida para $10^{\circ}$, ocasionalmente mais de 10 satélites estão visíveis dependendo da latitude de observador (PERREAULT (1980), RUTSCHEDT e ROTH (1982) apud HOFMANN-WELLENHOF (1994).

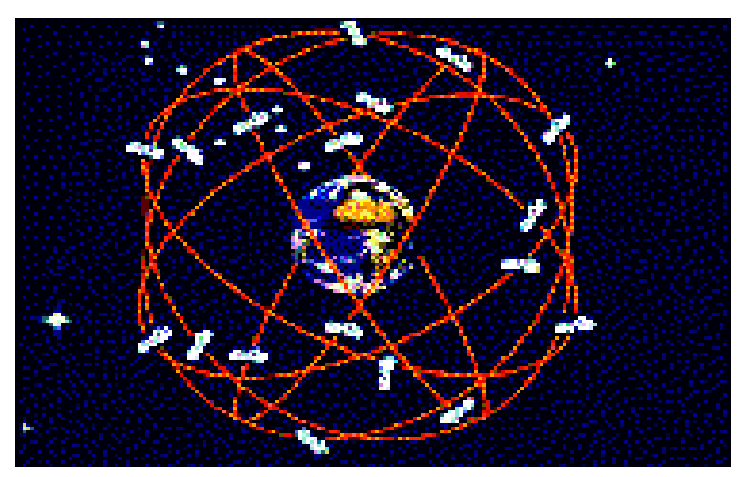

\section{Figura 13 - Constelação de Satélites do GPS}

Fonte: LEICK (1996) 
O GPS é originalmente um sistema de navegação. O princípio fundamental da navegação é baseado na medida das chamadas pseudodistâncias entre o usuário e de pelo menos quatro satélites (Figura 14). As coordenadas da antena do usuário podem ser determinadas através das coordenadas conhecidas dos satélites em um sistema de referência adequado. Do ponto de vista geométrico, três medidas de distância são suficientes. Uma quarta observação, entretanto, é necessária para resolver o erro de sincronização dos relógios do satélite transmissor e da estação receptora. O erro de sincronização é a razão para o termo “pseudodistância”. (SEEBER 1993).

WELLS et al. (1987) apud SEGANTINE (1996) definem a observação da pseudodistância, como sendo "a diferença entre o tempo de transmissão ( na escala de tempo do satélite) e o tempo de chegada (na escala de tempo do receptor) de um particular tipo de sinal transmitido pelo satélite, multiplicado pela velocidade da luz”. Pseudodistância também pode ser definida em função da medida da fase da portadora. Os relógios dos satélites e dos receptores GPS nunca estão sincronizados. Isto porque a maioria dos receptores usa versões simples de osciladores de cristal de quartzo. Todas as medidas da pseudodistância são degradadas por um mesmo erro de tempo, isto é, erro de sincronização, também chamada de erro do relógio do receptor. Este erro pode ser eliminado, matematicamente, pela medida da pseudodistância de quatro satélites (SEGANTINE 1996).

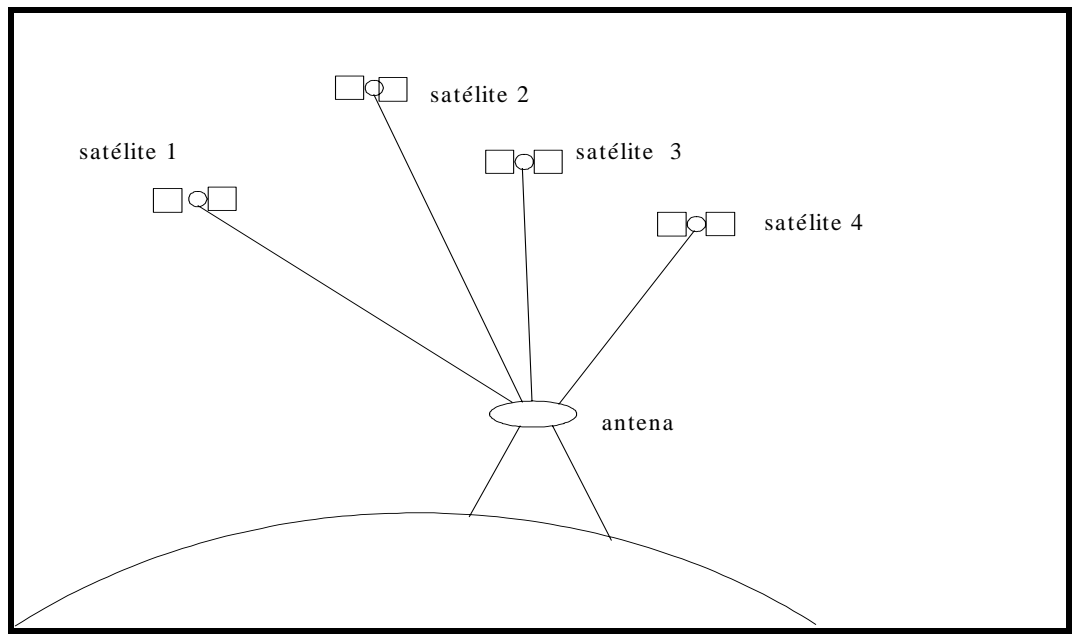

Figura 14 - Princípio Básico do Posicionamento com GPS 
Cada satélite transmite sinais nas freqüências L1 e L2. Estes são sinais de navegação (códigos), e dados de navegação e sistema (mensagem). Dois códigos diferentes estão em uso, o código P e o código C/A. O P significa Precision ou Protected (preciso ou protegido) e o C/A Clear/Aquisition. (SEEBER 1993). O sinal L1 contém o código preciso P e o código menos preciso C/A. A L2 contém somente o código P.

O equipamento eletrônico de cada satélite permite que o usuário meça a pseudodistância $\rho$ em relação ao satélite, e cada satélite transmite uma mensagem que permite que o usuário determine a posição espacial $\rho^{\mathrm{s}}$ do satélite para instantes arbitrários. Devido a esta capacidade, os usuários podem determinar sua posição $\rho_{R}$ na superfície terrestre ou acima desta conforme a Figura 15 (HOFMANWELLENHOF, 1994).

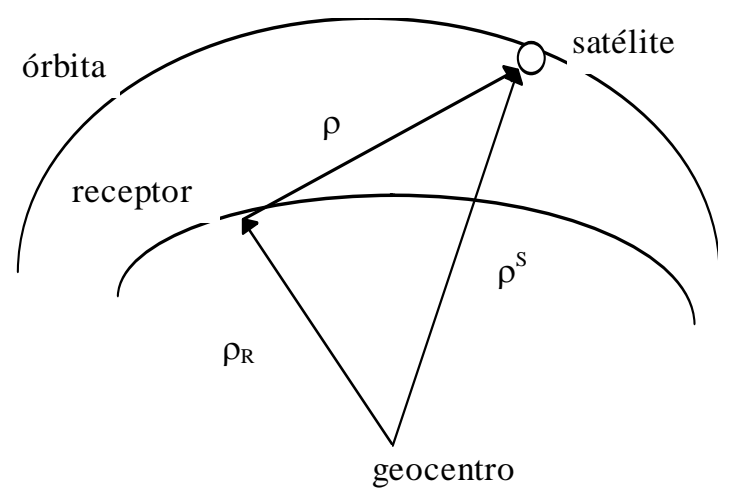

Figura 15 - Princípio do Posicionamento com Satélite

Fonte: HOFFMAN-WELLENHOF (1994) página 5 


\subsubsection{VANTAGENS E DESVANTAGENS DOS MÉTODOS}

O método convencional é restrito por problemas de intervisibilidade e um limitado alcance de utilização (GERDAN, 1992) e no caso de rodovias pela interferência no tráfego durante a realização do inventário. A grande vantagem desse método é a sua precisão, a qual serve de referencial para a comparação da precisão dos outros métodos.

A fotografia aérea tem alto custo de levantamento e restituição dos dados, sendo economicamente viável apenas em projetos de grande porte abrangendo grandes áreas. Freqüentemente, para projetos pequenos ou para aéreas com densa vegetação, um levantamento terrestre complementar é necessário (KAHMEN \& FAIG, 1988). O custo da foto aérea incluindo filme e o tempo de vôo é de U\$100 por milha ${ }^{2}$ (WOOD, 1989). Deve-se acrescentar a este preço o custo da restituição da foto e no caso de um SIG da digitalização dos mapas obtidos. Para o propósito de mapeamento, este sistema fornece uma precisão razoável (15 cm ou menos) (WOOD, 1989). A vantagem deste método é a possibilidade de se levantar grandes aéreas sem interferir no tráfego.

O sistema inercial (ISS), dentro dos seus limites operacionais, tem a desvantagem de requerer reajustes freqüentes em sua calibração e de não fornecer uma medida muito precisa, cerca de $20 \mathrm{~cm}$ no plano e $10 \mathrm{~cm}$ na elevação. Outra desvantagem é o custo relativamente elevado de aquisição do equipamento.

Dentro da precisão requerida para o levantamento do traçado de uma rodovia, entretanto, sua precisão é suficiente, com a vantagem adicional que permite o levantamento cinemático dos dados com velocidade de deslocamento elevada do veículo de medição. Pesquisas desenvolvidas na Inglaterra (SCHOFIELD, 1993) indicam que o levantamento com o ISS é 20 vezes mais rápido que o método convencional com EDM 
O GPS é o método que permite aliar o levantamento cinemático de dados com pequena interferência no tráfego da via, em um nível de precisão compatível com o EDM. A principal desvantagem do GPS é que, no método cinemático obstruções como pontes, edificações, árvores e cortes no terreno levam à perda do sinal, tornando necessário o uso de um método de medição complementar. NOVAK (1995) utiliza o ISS como sistema complementar, mas na ausência de recursos para a aquisição de um sistema inercial pode-se utilizar tanto o EDM como a fotogrametria, se houver fotos disponíveis, a um custo relativamente baixo.

Para avaliar a precisão das medidas da técnica de GPS cinemático (“stop-and-go) GERDAN (1992) determinou a diferença entre os dados obtidos pelo GPS e um EDM em um teste de campo. Para isto, utilizou dois receptores Trimble 4000SST e uma estação total Sokkia SET4B. O procedimento cinemático utilizado foi o stop and go. Para que fossem coletados os mesmos pontos pelos dois equipamentos, no bastão do receptor móvel foi acoplado o prisma da estação total. A comparação das coordenadas resultantes deste levantamento revelou uma discrepância nas coordenadas da ordem de 10-20 mm (discrepância média de 15 mm com desvio padrão de $6 \mathrm{~mm})$.

NEWCOMER (1990) apresenta as principais vantagens e desvantagens de se utilizar os métodos estático e cinemático com GPS. Dentro do método estático, ele mostra as precisões previstas para o EDM e o GPS apresentadas na Tabela 5. 
Tabela 5 - Erro versus Distância para o EDM e o GPS

\begin{tabular}{|c|c|c|c|c|}
\hline $\begin{array}{c}\text { Distância } \\
\text { (Km) }\end{array}$ & $\begin{array}{c}\text { Erro previsto } \\
\text { para o GPS } \\
\text { (m) }\end{array}$ & $\begin{array}{c}\text { Erro previsto } \\
\text { para o EDM 5/5 } \\
\text { (m) }\end{array}$ & $\begin{array}{c}\text { Erro previsto } \\
\text { para o EDM } 2 / 3^{2} \\
(\mathrm{~m})\end{array}$ & $\begin{array}{c}\text { Erro previsto } \\
\text { para o EDM 1/1 } \\
\text { (m) }\end{array}$ \\
\hline 1 & 0,007 & 0,010 & 0,005 & 0,002 \\
\hline 2 & 0,008 & 0,015 & 0,008 & 0,003 \\
\hline 3 & 0,009 & 0,020 & 0,011 & 0,004 \\
\hline 4 & 0,010 & 0,025 & 0,014 & 0,005 \\
\hline 5 & 0,011 & 0,030 & 0,017 & 0,006 \\
\hline
\end{tabular}

1 EDM com precisão de 5 mm + 5 ppm

2 EDM com precisão de $3 \mathrm{~mm}+2$ ppm

3. EDM com precisão de $1 \mathrm{~mm}+1 \mathrm{ppm}$

Fonte: NEWCOMER (1990) página 77

Em um levantamento realizado na França entre janeiro e fevereiro de 1988 por uma equipe formada pela Sercel e pelo Institut Geographique National (NARD \& WEEMS, 1989), foi estabelecida a diferença entre medidas com GPS e instrumentos EDM óticos, conforme é mostrado na Tabela 6.

Tabela 6 - Resultados no teste na França em 1988 com EDM óticos

\begin{tabular}{|c|c|c|c|c|c|c|}
\hline Data & Linha Base & $\begin{array}{c}\text { Distância Média } \\
\text { c\GPS } \\
\text { (m) }\end{array}$ & $\begin{array}{c}\text { GPS } \\
\delta \\
(\mathrm{mm})\end{array}$ & $\begin{array}{c}\text { Distância } \\
\text { ótica } \\
\text { (m) }\end{array}$ & $\begin{array}{c}\text { Ótica } \\
\delta \\
(\mathrm{mm})\end{array}$ & $\begin{array}{c}\text { Discrepância } \\
\text { GPS-Ótica }\end{array}$ \\
\hline 21 а $24 / 01$ & Sercel:M001-M002 & 98,8876 & 3,7 & 98,8873 & 0,5 & $+0,3$ \\
\hline 28 a 31/01 & Sercel-AGFA & 1180,438 & 4,4 & 1180,4385 & 2,8 & $-0,5$ \\
\hline 28 а 31/01 & Sercel MATRA & 2728,9918 & 1,7 & 2728,991 & 0,8 & $+0,8$ \\
\hline
\end{tabular}

Fonte: NARD \& WEEMS (1988) página 173 
CRIOLLO (1993) também mostrou a diferença entre o GPS e o método convencional. Ele realizou levantamentos com GPS através de vários tipos de métodos cinemáticos e comparou os resultados com os levantamentos realizados com o distanciômetro ELTA2 e o nível NI050. Ele encontrou uma diferença entre as coordenadas do GPS e do distanciômetro que varia de 0,74 a 2,41 cm para o método “stop-and-go", de 0,04 a 3,83 cm para o método cinemático contínuo e de 0,41 a 17,66 cm para o pseudo-cinemático. Com relação ao nivelamento, a diferença entre as coordenadas variou de 2,65 a 7,64 cm para o método “stop-and-go", de 1,93 a 4,26 cm para o método cinemático contínuo e de 1,25 a 93,59 cm para o pseudocinemático

Um exemplo da união das duas técnicas é o levantamento realizado em Washington D. C., em duas áreas, a Casa Branca e o Memorial Core descrito por PLING et al. (1994). Neste caso, o GPS foi utilizado nas áreas onde não existiam problemas de contato com os satélites devido a árvores, prédios altos e de multicaminhamento resultante do equipamento de rádio da Casa Branca.

Para distâncias entre pontos de medição maiores que 5 Km, o GPS tem se mostrado mais preciso que o EDM. Tem, portanto, uma grande aplicação em levantamentos de engenharia, com um efeito muito maior que o advento do EDM (SCHOFIELD, 1993).

O sistema de posicionamento global é capaz de fornecer melhores precisões de posicionamento do que as técnicas de levantamento tradicionais (LEICK 1990 apud SHRESTHA e CAMPBELL 1994). Além da alta precisão, o GPS oferece as seguintes vantagens significativas (SCHOFIELD, 1993):

- $\quad$ a posição é determinada diretamente em um sistema de coordenadas $\mathrm{X}, \mathrm{Y}, \mathrm{Z}$;

- não é necessária a intervisibilidade entre as estações terrestres;

- cada ponto é fixado separadamente, não existindo erro de propagação como acontece em redes; 
- os pontos levantados podem portanto ser selecionados de acordo com suas funções solicitadas;

- não é necessário que o operador tenha um elevado grau de habilidade;

- a posição pode ser fixada na terra, no mar ou no ar. Esta última facilidade pode ter um profundo efeito na aerofotogrametria;

- as medidas podem ser realizadas de dia ou de noite, em qualquer lugar do mundo, em qualquer tempo e em qualquer condições climáticas;

- medidas contínuas podem ser realizadas, resultando em um grande avanço para o monitoramento de deformações.

A outra grande vantagem deste sistema é a sua capacidade de integração com outros sistemas. O GPS aliado a um sistema de coordenadas e informações geográficas produz mapas; aliado a mapas, facilita a navegação; aliado a mapas digitais ou a um Sistema de Informações Geográficas (SIG) e a um sistema de comunicação, produz um sistema de controle (GIBBONS 1991b apud SEGANTINE 1996).

Ao se escolher um método para levantamento topográfico, deve-se levar em consideração:

- a precisão requerida,

- o tempo gasto,

- custo (equipamento e mão de obra),

- a disponibilidade do equipamento,

- as vantagens e desvantagens de cada técnica.

Com base no levantamento bibliográfico das várias técnicas existentes, escolheu-se o GPS porque :

- permite obter coordenadas (XYZ) precisamente,

- permite medir longas distâncias em um pequeno intervalo de tempo

- requer uma equipe de trabalho menor com menor habilidade 
- o levantamento pode ser realizado em qualquer horário e não depende das condições climáticas

- não necessita haver intervisibilidade entre as estações, aumentando a distância alcançada pelo equipamento

- pode trabalhar em conjunto com um SIG.

- não interfere muito no tráfego

Realizada a escolha do equipamento, deve-se avaliar como deve ser feito o levantamento, ou seja, estabelecer o método de coleta de dados, levando em consideração todas as limitações e recomendações da técnica GPS. 


\section{MÉTODO}

Para se realizar um levantamento topográfico com o GPS existem os seguintes métodos (SEEBER, 1993):

- método estático

- método rápido estático

- método cinemático

- método cinemático puro ('on-the-fly’)

- método "stop and go"

- método pseudocinemático

\subsection{MÉTODO ESTÁTICO}

O método estático é a técnica onde dois ou mais receptores envolvidos na missão, permanecem fixos nas estações durante toda a sessão de observação. O tempo necessário de observação varia, consideravelmente, com a capacidade do receptor usado na operação, com as características do programa usado no pós-processamento e com o comprimento da linha base. O uso típico do método estático inclui: determinação das coordenadas de pontos de controle para aerofotogrametria, levantamentos de divisa, levantamentos locais, implantação de redes geodésicas, avaliação do deslocamento de placas tectônicas e controle do deslocamento de barragens (SEGANTINE, 1996). 


\subsection{MÉTODO RÁPIDO ESTÁTICO}

Este método usa códigos ou combinações das portadoras para uma rápida inicialização no modo estático, isto é, resolução da ambigüidade. Este método requer medidas de ambos os códigos e das portadoras em ambas as freqüências. Observações de 5 a 10 minutos podem produzir precisões da ordem de 1 ppm (SEGANTINE, 1996).

\subsection{MÉTODO PSEUDOCINEMÁTICO}

Esta técnica desenvolvida por REMONDI (1988 apud HOFMANN-WELLENHOF, 1994) é também chamada de estático intermitente ou método da reocupação. Este levantamento necessita de um tempo menor de ocupação, mas deve-se ocupar um “par de pontos” duas vezes. Um cenário típico seria ocupar um par de pontos por cinco minutos, depois mover-se para outros pontos, e finalmente retornar para o primeiro par de pontos cerca de uma hora depois da ocupação inicial para uma ocupação de cinco minutos. Uma precisão subcentimétrica pode ser obtida. A principal vantagem deste método é que para um dado tempo de observação um número maior de pontos podem ser ocupados do que no método estático convencional. (HOFMANN-WELLENHOF, 1994). A segunda vantagem é que o receptor pode ser desligado durante o transporte. Isto faz com que o método seja muito útil em áreas com o sinal obstruído (HOFMANN-WELLENHOF, 1994). A desvantagem deste método é a necessidade de reocupação. As principais aplicações são: controle de foto e levantamentos em minas. 


\subsection{MÉTODO CINEMÁTICO}

O método cinemático envolve um receptor estacionário em um ponto de coordenadas conhecidas e um outro que se movimenta ao longo da trajetória. Para se obter os vetores com precisão em nível de centímetros, é necessário resolver a ambigüidade do sinal antes que o receptor móvel entre em movimento.

\subsection{MÉTODO CINEMÁTICO PURO ('ON-THE-FLY’)}

Em alguns casos, como na navegação aérea e marítima, não é possível resolver a ambigüidade através de métodos estáticos. Para resolver estes problemas foram desenvolvidas técnicas especiais que resolvem a ambigüidade durante o movimento. A diferença entre o método cinemático e o cinemático puro é a forma de resolver a ambigüidade.

\subsection{MÉTODO STOP-AND-GO}

Neste método, dois receptores ficam parados para resolver a ambigüidade durante um certo tempo dependo do técnica de resolução da ambigüidade (estas técnicas serão analisadas em maiores detalhes na seção 3.8.1). Depois um receptor permanece fixo, enquanto o outro se movimenta ao longo da trajetória. O receptor móvel pára nos pontos de interesse por um tempo mínimo de 5 épocas (1 época corresponde à taxa de armazenamento das informações do satélite, por exemplo: se a taxa de armazenamento for de $10 \mathrm{~s}$, então a cada $10 \mathrm{~s}$ completa-se uma época). As coordenadas do trajeto não são armazenadas apesar do receptor permanecer ligado. $\mathrm{O}$ 
receptor móvel pode afastar-se o quanto for necessário desde que mantenha o contato com quatro satélites. O método semi-cinemático é altamente eficiente em área abertas onde não existe nenhuma perda de ciclo devido à obstrução do sinal (HOFMANN-.WELLENHOFF, 1994)

Dentre os métodos acima descritos, escolheu-se o método cinemático, pois este permite determinar o perfil longitudinal rapidamente com uma boa precisão mesmo quando se utiliza receptores de código C/A. Alguns fatores devem, entretanto, ser levados em consideração para que a precisão seja satisfatória.

\subsection{FATORES QUE INTERFEREM NA PRECISÃO DO SISTEMA GPS}

A precisão das observações com os satélites GPS (SEGANTINE 1996) está relacionada com:

- $\quad$ tipo de observação:

- $\quad$ qualidade dos receptores;

- nível de erros e ruídos

- $\quad$ precisão de uma medida simples do código

- geometria dos satélites observados.

A precisão do posicionamento com GPS depende de dois fatores (SEEBER, 1993):

- a precisão de uma medida única da distância, expressa pelo User Equivalent Range Error (UERE) ou pelo desvio padrão associado $\sigma_{\mathrm{r}}$

- a configuração da geometria dos satélites . 
A geometria dos satélites visíveis é um importante fator na aquisição de resultados de alta qualidade especialmente para o posicionamento de pontos e levantamentos cinemáticos. A geometria muda com o tempo devido ao movimento relativo dos satélites. A medida da geometria é o fator Diluição da Precisão $\left(\right.$ DOP $\left.^{1}\right) .($ HOFMANN-WELLENHOF , 1994).

A relação entre $\sigma_{\mathrm{r}}$ e o desvio padrão associado ao posicionamento $\sigma$ é descrito por uma quantidade escalar a qual é freqüentemente utilizada na navegação e denominada DOP (SEEBER, 1993)

$$
\sigma=D O P^{*} \sigma_{r}
$$

Diferentes designações do DOP são utilizadas:

$$
\begin{array}{ll}
\sigma_{H}=H D O P^{*} \sigma_{r} & \text { para posicionamento horizontal } \\
\sigma_{V}=V D O P^{*} \sigma_{r} & \text { para posicionamento vertical } \\
\sigma_{P}=P D O P^{*} \sigma_{r} & \text { para posicionamento em 3D } \\
\sigma_{T}=T D O P^{*} \sigma_{r} & \text { para determinação do tempo }
\end{array}
$$

O efeito combinado da posição e do tempo é chamado:

$$
G D O P=\sqrt{(P D O P)^{2}+(T D O P)^{2}}
$$

PDOP pode ser interpretado como o valor recíproco do volume V do tetraedro que é formado através dos satélites e da posição do usuário (MILIKEN, ZOLLER, 1978 apud SEEBER 1993).

$$
P D O P=\frac{1}{V}
$$

\footnotetext{
${ }^{1}$ Dilution of Precision
} 
A Figura 16 fornece uma explicação geométrica. A melhor situação geométrica existe quando o volume é maximizado e, portanto, o PDOP é minimizado.

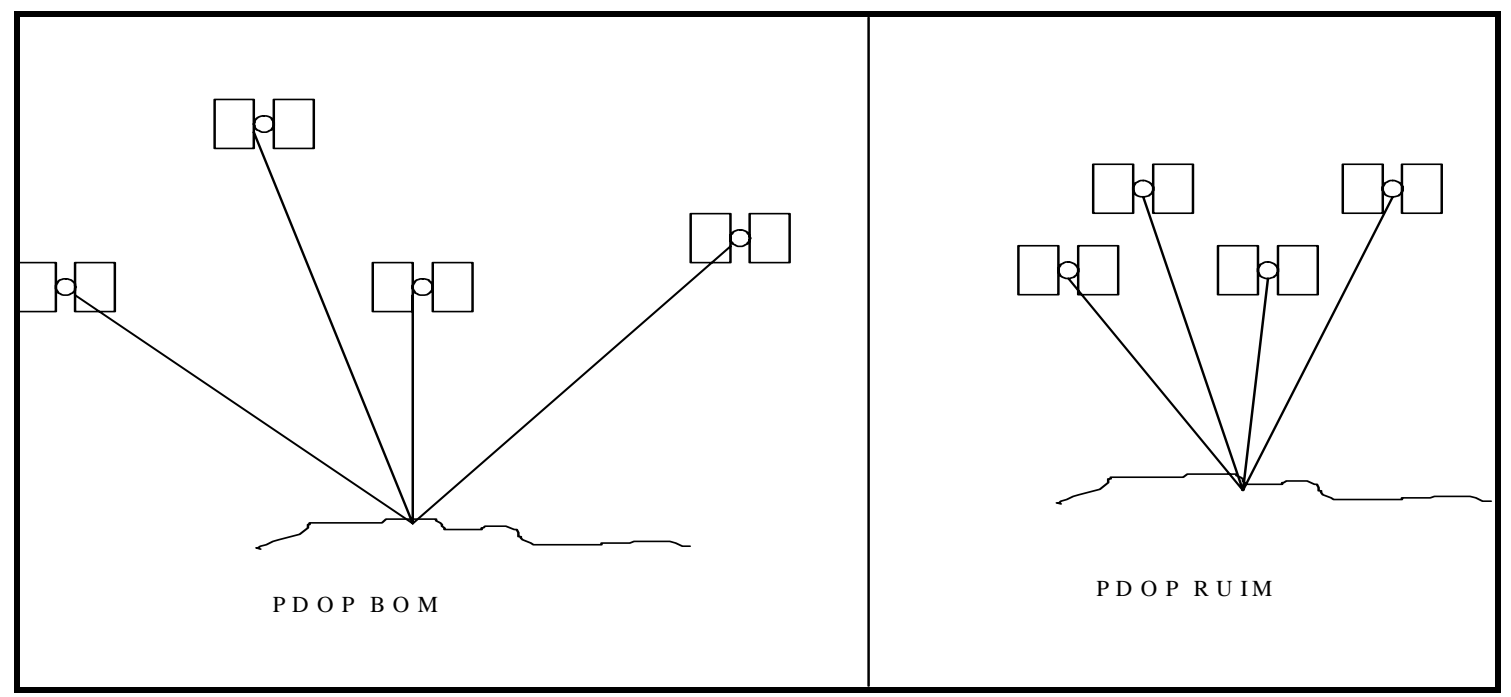

Figura 16 - Geometria dos Satélites e PDOP

Fonte: SEEBER (1993) página 293

Dependendo dos propósitos das observações, a configuração dos satélites pode ser selecionada com um valor favorável de DOP. Enquanto a configuração completa dos satélites não estava ainda instalada os valores de DOP para um dado local podiam mudar consideravelmente durante o dia, e a melhor “janela de observação” deveria ser selecionada (SEEBER, 1993). O valor mais comum para o DOP é o PDOP, que representa uma combinação de todos os fatores que afetam a precisão. Atualmente, com o sistema já concluído, o valor do PDOP não é mais crítico e, normalmente, apresenta valores inferiores a 3. Deve-se evitar observações no período em que o PDOP for superior a este valor (SEGANTINE, 1996). O GDOP reflete somente a geometria instantânea relativa ao um único ponto. Normalmente, GDOPs abaixo de seis são considerados bons e acima de seis são considerados muito elevados (HOFMANN-WELLENHOF, 1994).

A filosofia do DOP é mais interessante para a navegação. Se receptores com quatro canais forem utilizados, a melhor configuração com quatro satélites é 
automaticamente checada e selecionada. Isto é uma importante questão na navegação diferencial, porque satélites idênticos têm que ser utilizados nas duas estações. Uma conexão contínua de comunicação entre os observadores pode ser necessária.

Os números do DOP são menos interessantes para aplicações de levantamento, porque todos os satélites visíveis podem ser rastreados com receptores modernos e pode ser introduzido um processo rigoroso de ajustamento. Estimativas da precisão resultam do algoritmo de ajustamento e não do cálculo do PDOP. Os indicadores do DOP permanecem, contudo, uma importante ferramenta para o planejamento e controle do levantamento, principalmente para os métodos cinemáticos e rápido estático.

\subsubsection{ORIGEM DOS ERROS NO POSICIONAMENTO COM GPS}

Tanto as pseudodistâncias (código) como as fases da portadora são afetadas pelos erros sistemáticos ou erros e ruídos aleatórios. As fontes de erro podem ser classificadas em três grupos: erros relacionados com os satélites, erros relacionados com a propagação e erros relacionados com os receptores (Tabela 7).

\section{Tabela 7 - Erros das Distâncias}

\begin{tabular}{|l|l|}
\hline Fonte & Efeito \\
\hline Satélite & $\begin{array}{l}\text { Erro do relógio } \\
\text { Erro das orbitas }\end{array}$ \\
\hline Propagação do Sinal & $\begin{array}{l}\text { Refração ionosférica } \\
\text { Refração troposférica }\end{array}$ \\
\hline Receptor & $\begin{array}{l}\text { Variação do centro de fase da antena } \\
\text { Erro do relógio } \\
\text { Multicaminhamento }\end{array}$ \\
\hline
\end{tabular}

Fonte: HOFMANN-WELLENHOF (1994) página 93

Os erros sistemáticos podem ser eliminados pela combinação apropriada das observações. A diferença entre receptores elimina os erros específicos dos receptores. Então, a pseudodistância obtida através da dupla diferença é, em um alto 
grau, livre de erros sistemáticos com origem nos satélites e nos receptores. Com respeito à refração, isto é somente verdadeiro para pequenas linhas bases onde as distâncias medidas nos dois pontos finais são afetadas igualmente. A refração ionosférica pode ser potencialmente eliminada por uma combinação adequada dos dados das duas freqüências (HOFMANN-WELLENHOF, 1994).

\subsubsection{IONOSFERA}

O atraso na propagação na ionosfera (entre $50 \mathrm{~km}$ e $1000 \mathrm{~km}$ acima da superfície terrestre) depende da quantidade de elétrons ao longo do caminho do sinal e da freqüência usada. Os parâmetros que influenciam são principalmente a atividade solar e o campo geomagnético. Conseqüentemente, a refração ionosférica depende da freqüência, localização geográfica, e o tempo. O erro resultante na distância, para as freqüências GPS, pode variar entre menos de 1m até mais de 100 m (WELLS et al 1986, KLOBUCHAR 1991 apud SEEBER 1993.

\subsubsection{TROPOSFERA}

A troposfera é a região gasosa da atmosfera, que se estende da superfície terrestre até próximo dos $40 \mathrm{Km}$ de altura. O atraso na propagação da troposfera é crítico para o posicionamento preciso e determinação da linha base, em particular na determinação da componente da altura, devido à baixa correlação entre os parâmetros troposféricos sob grandes distâncias. A estrutura atmosférica próxima da superfície tem que ser modelada adequadamente. (SEEBER, 1993).

\subsubsection{MUTICAMINHAMENTO}

O sinal emitido pelo satélite chega ao receptor por vários caminhos. O multicaminhamento é principalmente causado por superfícies refletoras próximas ao 
receptor, conforme mostra a Figura 17. Estas reflexões podem ser horizontais, verticais ou inclinadas, isto é, o multicaminhamento é o resultado da interferência entre o sinal direto e o refletido e este fenômeno tem um comportamento aleatório. No entanto, ele pode aparecer em termos de pequenos ruídos de sinais (SEGANTINE, 1996). Efeitos secundários são as reflexões no satélite durante a transmissão.

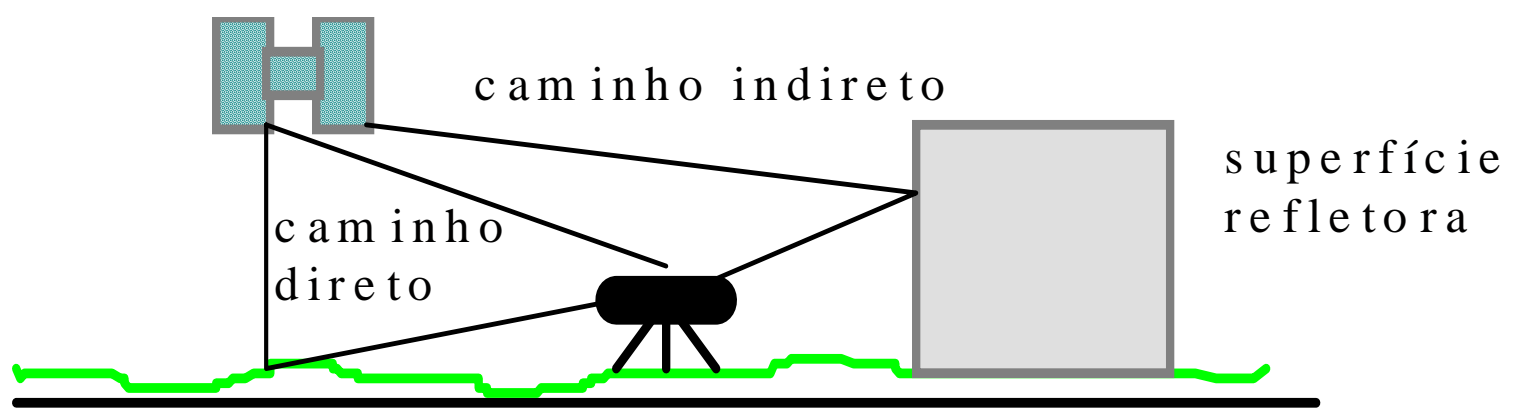

\section{Figura 17 - Representação do Multicaminhamento}

Fonte: SEGANTINE (1996) página 68

O sinal do satélite chega no receptor em três caminhos diferentes, um direto e dois indiretos. Como conseqüência, os sinais recebidos têm compensação de fase relativa e a diferença de fase é proporcional à diferença do comprimento dos caminhos, conforme TRANQUILLA (1986) apud HOFMANN-WELLENHOF (1994). Não existe nenhum modelo geral para o efeito do multcaminhamento devido a diferentes situações geométricas. Esta influência do multicaminhamento, contudo, pode ser estimada pela combinação dos códigos da L1 e L2, e das medidas da portadora, conforme EVANS (1986) apud HOFMANN-WELLENHOF (1994).

O princípio é baseado no fato de que a troposfera, os erros do relógio e os efeitos relativísticos influenciam a fase do código e portadora pelo mesmo montante. O mesmo não acontece com a refração na ionosfera e o multicaminhamento os quais dependem da freqüência. Considerando o código livre da ionosfera e a fase da portadora, e formando as correspondentes diferenças, todos os efeitos anteriormente 
mencionados, exceto o multicaminhamento, são cancelados. A recomendação geral é evitar, o quanto for possível, superfícies refletoras nas vizinhanças do receptor.

Do ponto de vista geométrico os sinais recebidos de satélites com elevação baixa são mais suscetíveis ao multicaminhamento do que os com elevação alta. Também pode ser notado que as distâncias medidas através do código são mais afetadas pelo multicaminhamento do que as fases da portadora., conforme EVANS (1986) apud HOFMANN-WELLENHOF (1994). Sob certas circunstâncias, o erro resultante do multicaminhamento pode chegar a cerca de 100 m próximo a prédios, conforme NEE (1992) apud HOFMANN-WELLENHOF (1994).

O multicaminhamento do sinal do código vem a ser particularmente crítico, quando a técnica de combinação do código/portadora é usada para a resolução da ambigüidade ‘on the fly’ (OTF)² (SEGANTINE (1996) ) que será apresentada adiante.

HOFMANN-WELLENHOF et al (1994) apud SEGANTINE (1996) indicam algumas alternativas para reduzir os efeitos do multicaminhamento:

- colocar a antena diretamente sobre o terreno, sem o tripé, a fim de eliminar caminhos indiretos. Mesmo assim podem ocorrer as reflexões verticais. Recomenda-se evitar possíveis superfícies refletoras próximas dos receptores;

- selecionar antenas que usem a polarização de sinais. Os sinais GPS são sinais polarizados circularmente, à direita ou à esquerda, enquanto que os sinais refletidos são polarizados circularmente com sentido oposto ao original;

- usar filtros digitais, antenas de banda larga e planos terrestres de rádio freqüência, que reduzem a interferência dos sinais dos satélites nas condições de pequenos ângulos de elevação;

- omitir, se possível, os satélites de baixa elevação, pois os efeitos do multicaminhamento são mais acentuados em satélites de pequena elevação.

\footnotetext{
${ }^{2}$ ambiguidade 'on the fly'(OTF) é a técnica de resolução da ambiguidade durante o movimento do receptor
} 
Na prática, o multicaminhamento pode não ser um problema. Deve-se utilizar o bom senso e o julgamento na seleção dos locais para medição com GPS. Locais próximos a cercas e construções metálicas devem ser evitados. Quando um ponto estiver próximo a uma cerca, a antena pode ser elevada acima desta. Ao realizar levantamentos estáticos, onde os períodos de observação tendem a ser relativamente longos, os períodos intermitentes de contaminação pelo multicaminhamento não são um problema. Situações críticas podem ocorrer quando o receptor é instalado junto a uma rodovia e grandes caminhões metálicos passam continuamente pela antena.

\subsubsection{PERDA DE CICLOS}

Quando o receptor é ligado, uma fração de ciclos da portadora de fase (dado pela diferença entre a portadora transmitida pelo satélite e uma réplica gerada internamente pelo receptor) é observada, e, é iniciado o contador de ciclos inteiros. Durante a observação, o contador é incrementado de uma unidade, embora a fração de fase varie de $2 \pi$ a 0 . Então, para uma dada época, a fase acumulada observada, $\Delta \varphi$, cf REMONDI 1984 ou REMONDI 1985 apud HOFMANN-WELLENHOF 1994, é a soma da fração de fase $\varphi$, e o número de inteiros N. 
O número inicial de ciclos inteiros, $\mathrm{N}$, entre o satélite e o receptor, é um parâmetro desconhecido (HOFMANN-WELLENHOF 1994). Esta ambigüidade de N continua constante, enquanto não ocorrer um dos fenômenos abaixo relacionados (SEGANTINE 1996):

- um bloqueio temporário de sinais, devido à presença de árvores, edifícios, pontes, montanhas, etc, principalmente em observações cinemáticas;

- ocorrência de sinais fracos, devido às más condições ionosféricas, multicaminhamento, deslocamentos bruscos das antenas receptoras ou satélites de baixa elevação;

- falha no programa do receptor;

- informação enviada pelo satélite incompleta ou incorreta;

- mal funcionamento dos osciladores dos satélites;

- inclinação da antena em aplicações cinemáticas (aviões, barcos) (SEEBER, 1993).

Uma representação gráfica da perda de ciclo é mostrada na Figura 18 (HOFMANNWELLENHOF 1994).

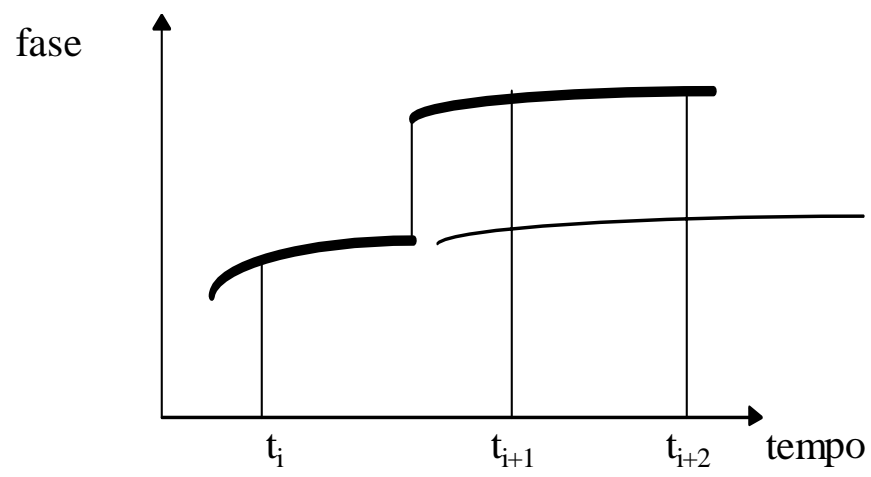

Figura 18 - Representação Gráfica da Perda de Ciclo

Fonte: HOFMANN-WELLENHOF (1994) página 205 
Se um dos fenômenos descritos anteriormente ocorrer, o contador de inteiros reiniciará a contagem e ocorrerá um salto na fase, que é chamado de perda de ciclo e somente ocorre durante a medida da fase. A perda de ciclo apresenta a característica de que após sua ocorrência, todas as observações se apresentam alteradas de um mesmo número de inteiros. A perda de ciclos tem que ser removida dos dados quando forem processados, ou uma nova ambigüidade tem que ser determinada para uma distância particular. A perda de ciclos é fácil de ser detectada se a dupla e a tripla diferença forem montadas. (SEBEER, 1993)

Dois aspectos devem ser distinguidos, a detecção da perda de ciclos e a eliminação da perda de ciclos dos dados, o reparo da perda de ciclos. Muitos dos receptores modernos têm algoritmos que identificam toda ou grande parte da perda de ciclos, e indicam as perdas na série de dados. Estas indicações são úteis no processamento dos dados. Provavelmente, as próximas gerações de receptores terão a capacidade de remover a perda de ciclos dos dados. Mas, atualmente, o reparo da perda de ciclos pertence ao processo de edição dos dados, tanto automática como interativa.

Muitos métodos estão em uso e têm sido amplamente discutidos na literatura. As principais diferenças são (SEEBER, 1993):

- a série de dados disponível (dupla ou única freqüência, código P)

- conhecimento a priori disponível (coordenadas das estações, coordenadas dos satélites)

- tipo de observação (estática ou cinemática)

A perda de ciclos não pode ser identificada e corrigida através de séries únicas de medidas de fase sozinhas. Basicamente, as observações da fase são comparadas e combinadas com outras quantidades e o comportamento das diferenças são analisados. As diferenças podem ser consideradas como sendo "teste de quantidades" que devem mostrar o comportamento ajustado. Qualquer descontinuidade nas séries de dados do teste de quantidade indica uma perda de ciclo.

Diferentes aproximações são utilizadas para identificar esta descontinuidade: 
- um polinômio de baixo grau é ajustado às séries de tempo; este método é amplamente utilizado;

- um modelo dinâmico é instalado para prever as observações subsequentes através do filtro de Kalman (e.g. LANDAU 1986 apud SEEBER 1993). Uma comparação entre o dado previsto e o observado indica uma possível perda de ciclo.

- um esquema da primeira, segunda, terceira e quarta diferença pode ser estabelecido. Discontinuidades mostram sinais bastante fortes nas diferenças de alta ordem (e.g. HILLA 1986 apud SEEBER 1993)

Os principais procedimentos podem ser identificados:

- análise da dupla diferença e das distâncias calculadas

- análise dos resíduos da ionosfera

- análise da combinações código/portadora

- métodos utilizados nas aplicações cinemáticas

No método cinemático, as ambigüidades inteiras da fase são resolvidas antes do receptor móvel iniciar. Enquanto o contato da fase é mantido as posições cinemáticas da antena móvel podem ser deduzidas. Se mais de quatro satélites forem rastreados e pelo menos quatro satélites continuem em contato, as perdas de ciclos podem ser corrigidas com os satélites remanescentes e o levantamento pode continuar.

Se restarem menos de quatro satélites, os seguintes procedimentos podem ser aplicados:

1. Retornar às coordenadas do último ponto e iniciar com uma nova determinação da ambigüidade da fase inicial. Este método não é praticável em aplicações aéreas e marinhas; para aplicações terrestres um indicador da perda de ciclo no receptor para alertar é útil (cf. e.g. ALLISON, ESCHENBACH 1989 apud SEEBER 1993); 
2. Com receptores de dupla freqüência os resíduos ionosféricos podem ser utilizados em conjunto com o filtro de Kalman, para prever o comportamento dinâmico da plataforma de observação e fechar os gaps nas observações.

3. Com receptores de código P e técnica de banda extra-larga, a ambigüidade pode ser resolvida “on-the-fly” (SEEBER, WÜBBENA 1989 apud SEEBER 1993). O mesmo é possível com receptores de código C/A e um grande número de satélites visíveis (> 6-8) usando técnicas avançadas de resolução da ambigüidade (WÜBBENA 1989 apud SEEBER 1993). Para cada perda de ciclo, um novo parâmetro da ambigüidade é simplesmente introduzido no ajustamento.

4. A integração com um sensor adicional é útil para cobrir os gaps, causados pelas perdas de ciclos. Um relógio atômico externo substitui um satélite. Um sensor inercial pode ser utilizado para interpolar as posições GPS se os sinais de um satélite particular forem encobertos por obstruções (e.g. LOOMIS, GEIER 1991 apud SEEBER 1993).

\subsection{6. “ANTISPOOFING”(AS)}

O projeto do GPS inclui a habilidade de essencialmente “desligar” o código P ou invocar o código encriptado como um meio de danificar o acesso ao código P para todos os usuários não autorizados. A justificativa de ser feito isto é para deter os adversários mandando falsos sinais para criar confusão.

O A-S é realizado pela soma do MODULO 2 do código P e do código encriptado W. O código resultante é denotado por código Y. Portanto, quando o A-S está ativo, o código P nas portadoras L1 e L2 é trocado por um código Y desconhecido. O A-S ou está desligado ou ligado. Desta forma, uma influência variável do A-S (como é o caso do SA) não pode ocorrer. (HOFMANN-WELLENHOF, 1994) 


\subsection{7. “SELECTIVE AVAILABILITY”(SA)}

O objetivo do SA é degradar a precisão da navegação através da manipulação dos dados do relógio do satélite (processo $\delta$ ) e manipular as efemérides (processo $\varepsilon$ ). $O$ SA foi somente implementado nos satélites do Bloco II e tem sido utilizado desde março de 1990 em vários níveis de danos à precisão.

Segundo as especificações do $\mathrm{DoD}$, a precisão é degradada para $100 \mathrm{~m}$ para a posição horizontal e 156 m para a posição vertical. Estas especificações também implicam em um erro de 0,3 metros por segundo na velocidade e um erro de 340 ns no tempo. Todos estes números são dados com um nível de 95\% de probabilidade, conforme OLSEN (1992) apud HOFMANN-WELLENHOF (1994).

\subsection{MÉTODO UTILIZADO NO LEVANTAMENTO}

Para realizar o levantamento das coordenadas dos pontos que foram utilizados na representação da rodovia em planta e perfil, foi utilizado o método cinemático. O posicionamento cinemático relativo envolve um receptor estacionário em um ponto de coordenadas conhecidas e um outro que se movimenta ao longo da trajetória (Figura 19). Para se obter os vetores com precisão em nível de centímetros, é necessário resolver a ambigüidade do sinal antes que o receptor móvel entre em movimento. Caso ocorra perda de ciclo, ou o número de satélites fique abaixo de 4 durante o trajeto, a ambigüidade deve ser determinada novamente. Por isso, devemse evitar os locais que obstruam o sinal do satélite como árvores, prédios, etc. 


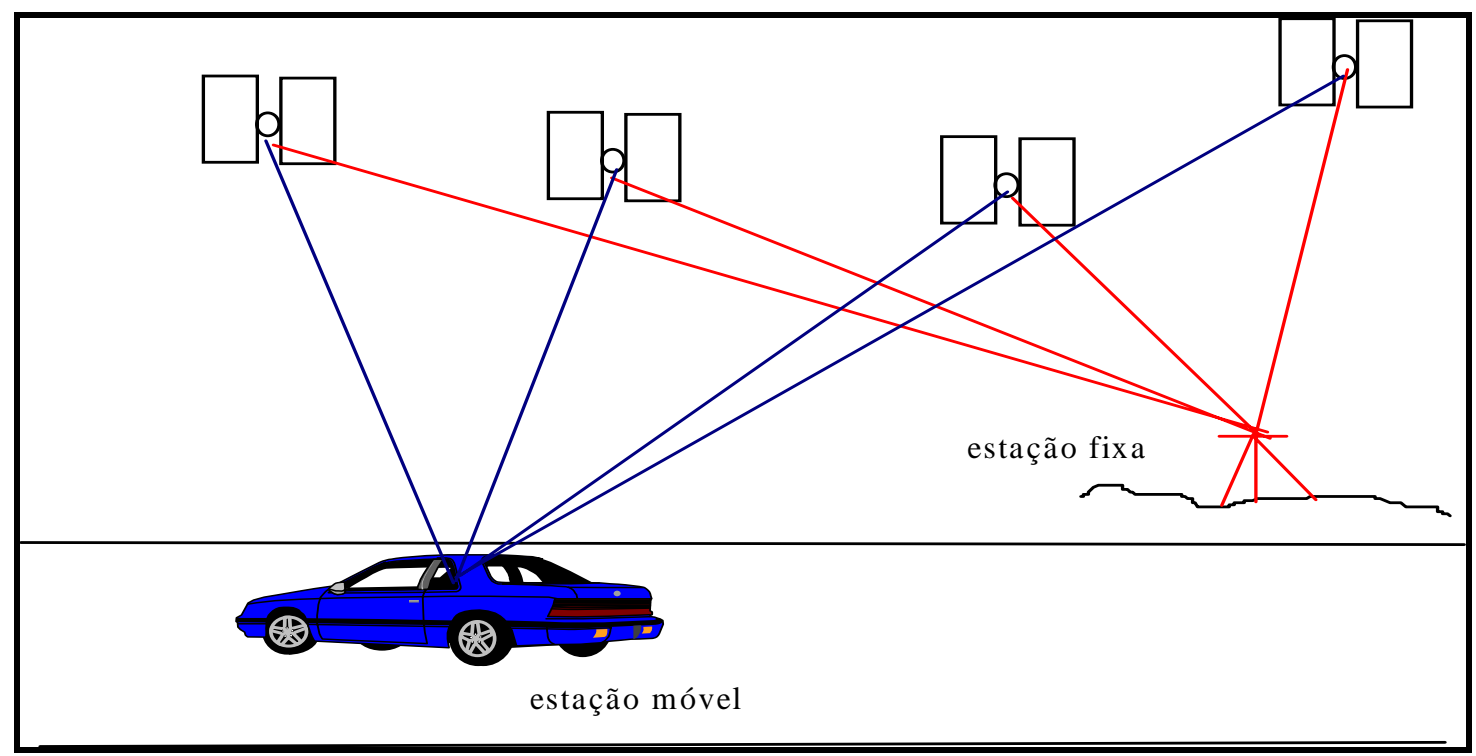

Figura 19 - Método Cinemático

Desde a criação do sistema, sabe-se que as observações da fase da portadora, em conjunto com a técnica da resolução da ambigüidade, proporcionam aplicações de alta precisão. Fisicamente, a fase da portadora é mais complexa de se definir do que a pseudodistância. Para uma época t $t_{0}$ quando o sinal do satélite é recebido pelo receptor, as observações da fase da portadora são consideradas como sendo a diferença de fase, que vem no sinal do satélite e a fase gerada internamente, dentro do receptor. Quando comparado com o comprimento de onda do sinal, a fase da portadora representa uma parte da diferença de medida de fase do sinal emitido pelo satélite e a fase do sinal gerada pelo receptor, com uma grande porção da medida relacionada com certos números de ciclos de sinais de conhecimento prévio. Este número inteiro de ciclos, usualmente, é conhecido por ambigüidade de ciclos (número de ciclos ou número inteiro da ambigüidade - cycle ambiguity) da portadora (SEGANTINE,1996). As técnicas de resolução da ambigüidade são apresentadas a seguir. 


\subsubsection{FORMAS DE RESOLUÇÃO DA AMBIGÜIDADE}

A determinação da ambigüidade é um dos problemas mais exigentes na técnica geodésica para avaliar as observações. A melhor e mais simples possibilidade para determinar a ambigüidade pode ser o uso de freqüências adicionais ou sinais. O GPS não fornece mais que duas freqüências, portanto estratégias particulares foram desenvolvidas para resolver o problema da ambigüidade.(SEEBER, 1993)

Em muitos casos, em particular se a distância entre estações for pequena, e se a qualidade dos dados for boa, a resolução da ambigüidade funciona satisfatoriamente com opções rotineiras no software fornecido pelo fabricante do GPS. O problema fundamental é determinar a ambigüidade inicial antes de começar o levantamento, ou durante o percurso, caso haja uma perda de ciclo. Isto pode ser feito através de procedimentos de inicialização estática e cinemática.

Três técnicas de inicialização estática estão em uso (SEEBER, 1993):

- a determinação de uma linha base inicial com levantamento estático anterior as operações cinemáticas

- observação curta de uma linha base conhecida

- troca de antenas

O primeiro método é o mais demorado. Um dos receptores é instalado no ponto de referência e o outro (receptor móvel) fica parado em um ponto qualquer até que se obtenham dados suficientes para determinar as coordenadas deste ponto desconhecido e conseqüentemente a ambigüidade. 


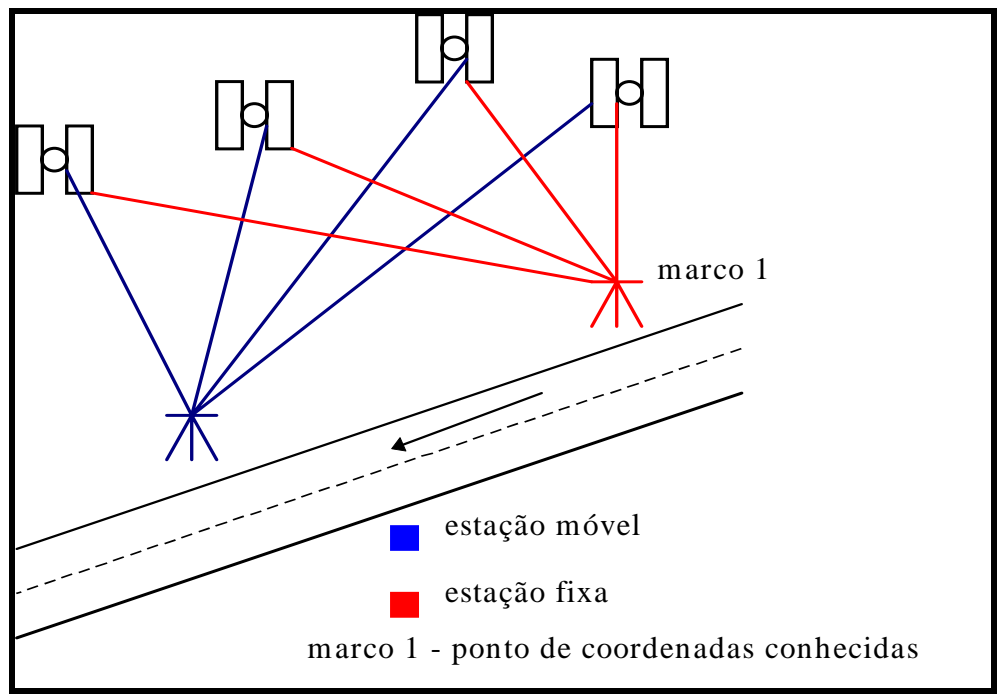

Figura 20 - Método de Determinação da Ambigüidade Através do

\section{Levantamento Estático}

O segundo método necessita de uma linha base precisamente determinada. Note que as três dimensões das diferenças das coordenadas cartesianas devem ser prédeterminadas com uma precisão da ordem de centímetros. O método é muito rápido porque somente dados de cerca de um minuto de observação são necessários. Depois da inicialização, um receptor permanece na estação e o segundo inicia o levantamento.

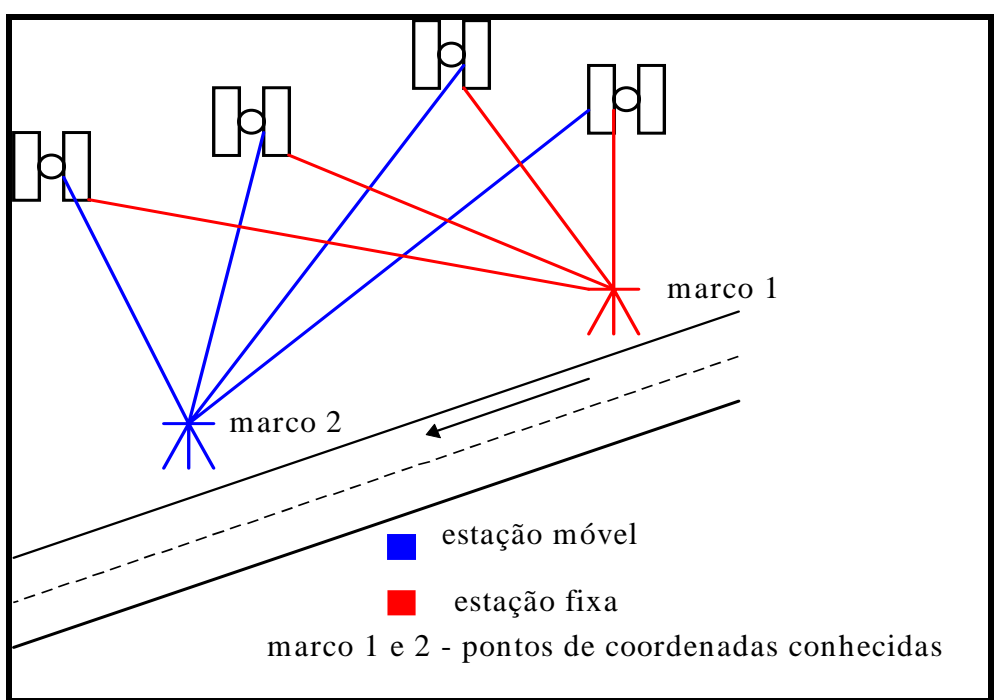

Figura 21 - Método de Determinação da Ambigüidade Através de uma Linha Base conhecida 
O terceiro método é amplamente utilizado porque é rápido, preciso, e seguro e não necessita de um conhecimento anterior da linha base. O procedimento foi primeiramente descrito por REMONDI (1985 apud SEEBER, 1993). Dois receptores são colocados próximos em duas estações. Uma estação deve ter coordenadas conhecidas porque servirá como estação de referência para o levantamento. A segunda estação pode ser selecionada arbitrariamente. Cerca de um minuto de dados comuns são observados. Então as antenas são trocadas, mantendo-se o contado com os satélites, e novamente os dados são coletados por cerca de um minuto. O procedimento pode ser terminado aqui, mas alguns softwares necessitam de uma troca posterior das antenas para a posição original para propósitos de controle.

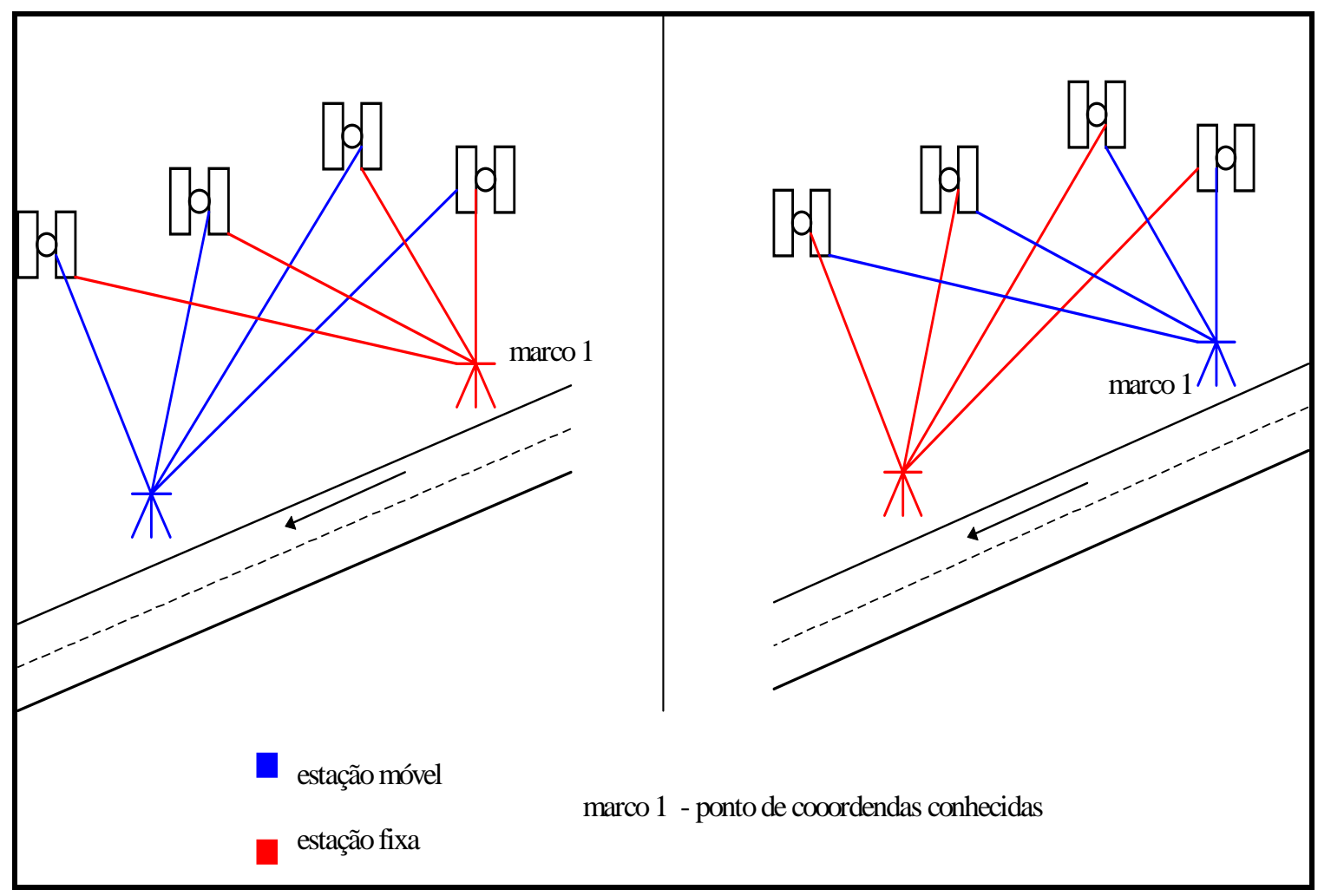

Figura 22 - Troca de Antenas - Antena Swap

Aplicações especiais necessitam do método de levantamento cinemático sem inicialização estática, pois o objeto em movimento cuja posição deve ser calculada está em permanente movimento (por exemplo, o avião durante o vôo) (HOFMANNWELLENHOF, 1994). Neste caso, a ambigüidade deve ser resolvida durante o 
trajeto através de métodos de inicialização cinemática realizados através da técnica conhecida como "on-the fly. Esta técnica é mais eficiente com receptores de dupla freqüência, onde a ambigüidade é resolvida através da técnica da banda larga e funções de pesquisa da ambigüidade (SEEBER, 1993), ou pela integração dos dados GPS com sistemas inerciais de navegação (INS). Desta forma, a coleta é mais rápida, pois, o veículo não precisa parar em nenhum ponto do trecho de medição.

Durante a fase de coleta de dados no método cinemático é condição necessária não haver perda de contato com os satélites, ou seja, deseja-se que não ocorra perda de ciclo, portanto ele possui restrições de medição em áreas obstruídas, próximas de construções, árvores ou viadutos. Dentre os métodos de inicialização estática e cinemática acima descritos, adotou-se o método de linha base conhecida para resolver o problema da ambigüidade no caso de perda do sinal. Comparando-se os métodos de inicialização estática e cinemática optou-se pelo primeiro pelo custo mais baixo. Entre os métodos de inicialização estática, optou-se pelo segundo método, por ser mais rápido que o primeiro e por ser impossível realizar a troca de antenas no meio do percurso caso ocorresse uma perda de ciclo.

Podem surgir problemas para resolução da ambigüidade nos seguintes casos (SEEBER, 1993):

- as distâncias entre estações for maior que $10 \mathrm{~km}$ e necessita-se de uma alta precisão;

- a qualidade dos dados não é boa;

- $\quad$ somente poucos satélites estão disponíveis $(\leq 4)$;

- $\quad$ existe perturbação ionosférica;

- o tempo de observação é pequeno,

De acordo com estas informações, adotou-se o espaçamento máximo entre o receptor fixo e o móvel de $10 \mathrm{~km}$. Optou-se por colocar marcos a cada $5 \mathrm{~km}$ para permitir que a ambigüidade seja resolvida durante o trajeto rapidamente. 


\subsubsection{LEVANTAMENTOS DOS PONTOS UTILIZADOS NA RESOLUÇÃO DA AMBIGÜIDADE}

Para resolver a ambigüidade, marcos foram colocados ao longo da estrada. As coordenadas destes pontos foram determinadas através do método estático. O método de levantamento estático é a técnica onde dois ou mais receptores envolvidos na missão, permanecem fixos nas estações durante toda a sessão de observação (Figura 23). Este método requer algumas horas de observações para medir a fase dos sinais das portadoras, que alcançam as antenas dos receptores. (SEGANTINE, 1996).

Neste método, as medidas são obtidas dos mesmos quatro ou mais satélites simultaneamente para os dois receptores por um período variando entre 0,5 até duas horas dependendo da precisão. Quanto maior a precisão desejada e a distância entre os pontos, maior será o tempo de observação necessário. Estas medidas são levadas para uma central e pós-processadas para determinar o vetor tridimensional relativo entre os dois pontos. Estes vetores são aplicados nos pontos de referência conhecidos para determinar a posição dos pontos desconhecidos. (LOGAN, 1988). Para aplicações práticas, uma precisão de $\pm 1 \mathrm{ppm}$ ou $1 \mathrm{~mm}$ para uma linha base de $1 \mathrm{~km}$ pode ser obtido. A precisão do método estático pode ser observada na Tabela 8. (HOFMANN E WELLENHOF 1994 )

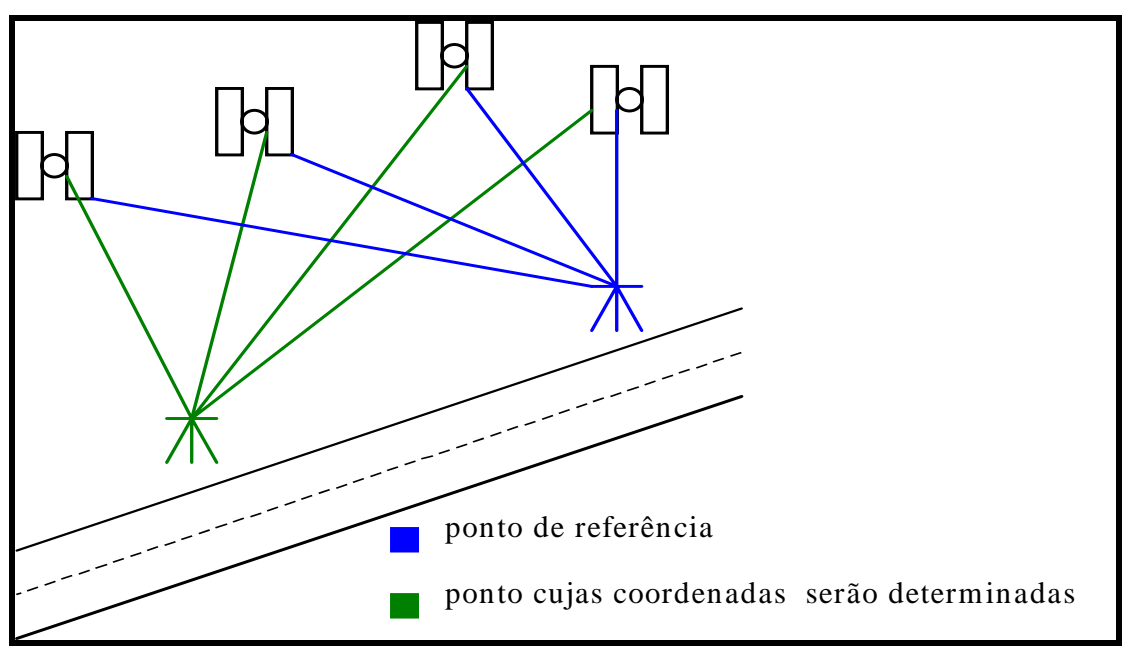

Figura 23 - Método Estático 
Tabela 8 - Precisão do Método Estático

\begin{tabular}{|c|c|c|c|c|}
\hline Freqüência & $\begin{array}{c}\text { Linha Base } \\
{[\mathbf{k m}]}\end{array}$ & Satélites & $\begin{array}{c}\text { Tempo de Observação } \\
{[\mathbf{m i n}]}\end{array}$ & $\begin{array}{c}\text { Precisão } \\
\text { [ppm] }\end{array}$ \\
\hline \multirow{2}{*}{ simples } & 1 & 4 & 30 & $5-10$ \\
\cline { 2 - 5 } & 5 & 5 & 15 & 5 \\
\cline { 2 - 5 } & 10 & 5 & 60 & 4 \\
\cline { 2 - 5 } & & 4 & 90 & 3 \\
\cline { 2 - 5 } & 30 & 5 & 60 & 0,1 \\
\cline { 2 - 5 } & & 5 & 120 & 1 \\
\hline dupla (código C/A) & 100 & 5 & 90 & 0,1 \\
\hline dupla (código P) & 50 & 4 & 120 & $0,1-0,01$ \\
\cline { 2 - 5 } & 100 & 5 & 10 & \\
\cline { 2 - 5 } & 500 & 5 & 120 & \\
\hline
\end{tabular}

Fonte: SEGANTINE (1996)

\subsubsection{INSTALAÇÃO DA ESTAÇÃO MÓVEL}

Para realizar o levantamento cinemático, a antena da estação móvel foi colocada em um suporte em cima do automóvel a uma altura que minimiza os efeitos do multicaminhamento (Figura 24). A haste do suporte tem $2 \mathrm{~m}$ de altura. 


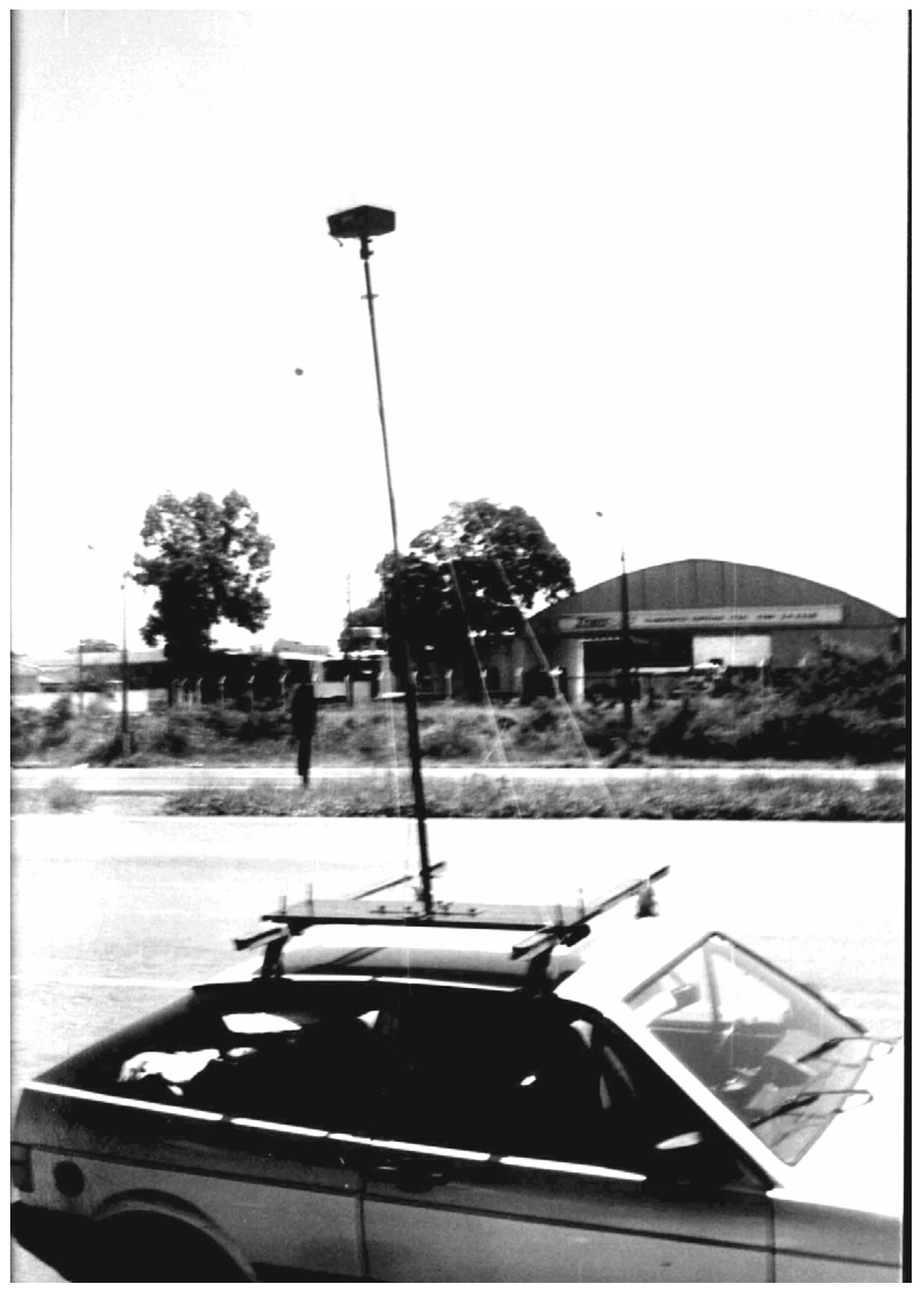

Figura 24 - Suporte da antena 


\section{ESTUDO DE CASO}

Para analisar a exeqüibilidade deste método de levantamento de dados, escolheu-se como área a ser levantada um trecho de pista simples que vai do Km 0+00 até o Km 32+000 da SP-127 Rodovia Fausto Santo Mauro, que liga as cidades de Rio Claro e Piracicaba. (Figura 25). Este local foi escolhido devido ao alto índice de acidentes e por ser possivelmente duplicada futuramente. A aquisição dos dados antes e depois da duplicação poderá ser utilizada no estudo da relação da geometria da via com a ocorrência de acidentes neste trecho da rodovia. 


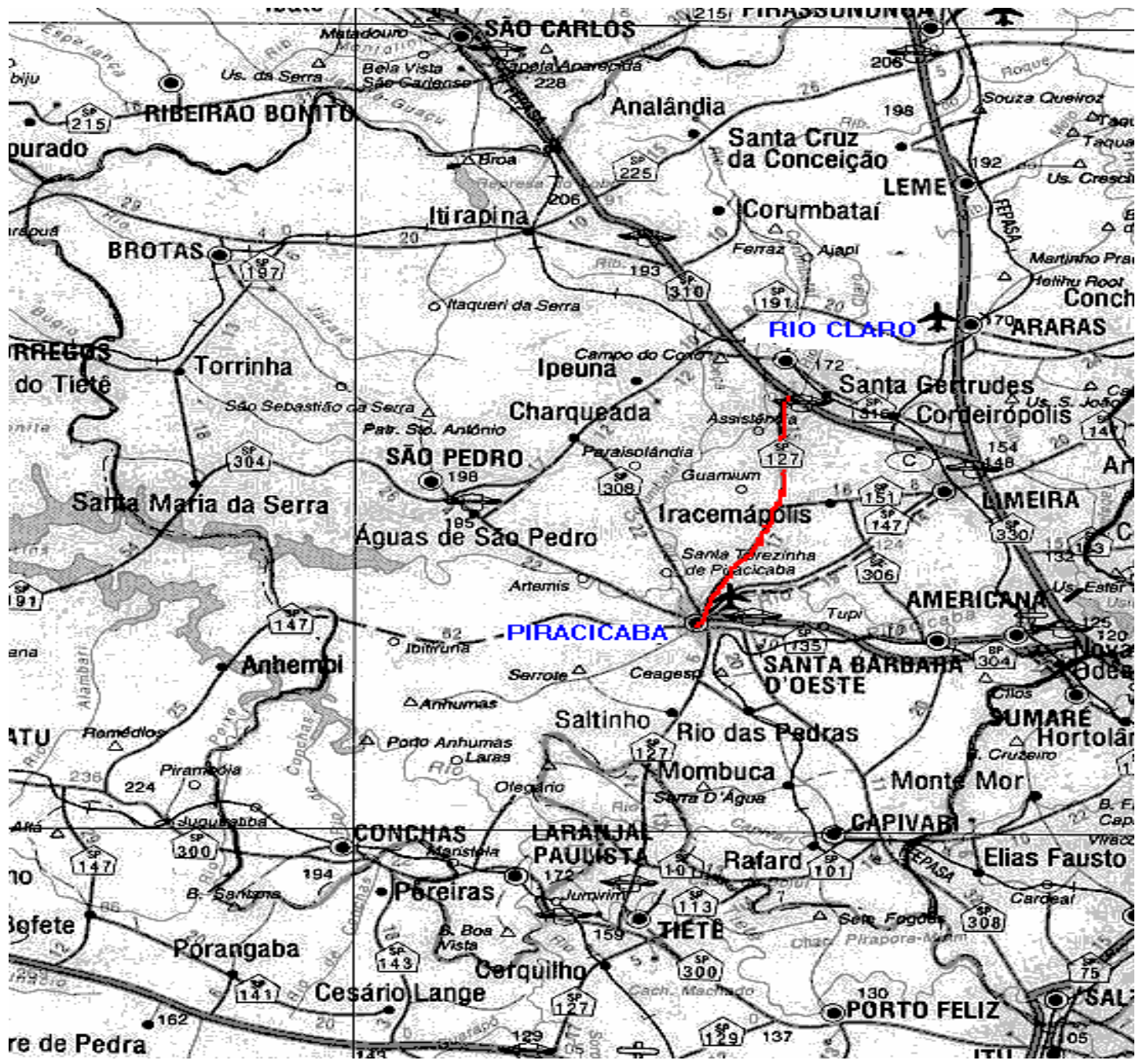

Figura 25 - Localização do Trecho a ser Analisado

A reconstituição da rodovia foi divida em duas etapas:

1. Levantamento estático para determinação dos pontos que serviram para determinação da ambigüidade através do método de linha base conhecida e para servir como ponto de referência para o levantamento cinemático

2. Levantamento cinemático 


\subsubsection{LEVANTAMENTO ESTÁTICO}

Após a seleção do local, marcos foram colocados a cada $5 \mathrm{Km}$ aproximadamente (Figura 26). Para determinar as coordenadas dos pontos ao longo da rodovia com precisão foi tomado como ponto de referência, um ponto de coordenadas conhecidas. Para este trabalho utilizou-se o marco situado na Universidade Federal de São Carlos para determinar as coordenadas do marco 1 localizado próximo ao Km 0+00 da SP127. O tempo de observação foi de 150 minutos. No levantamento estático, utilizouse o equipamento da TRIMBLE 4000SST de dupla freqüência sem o código P (Figura 27).

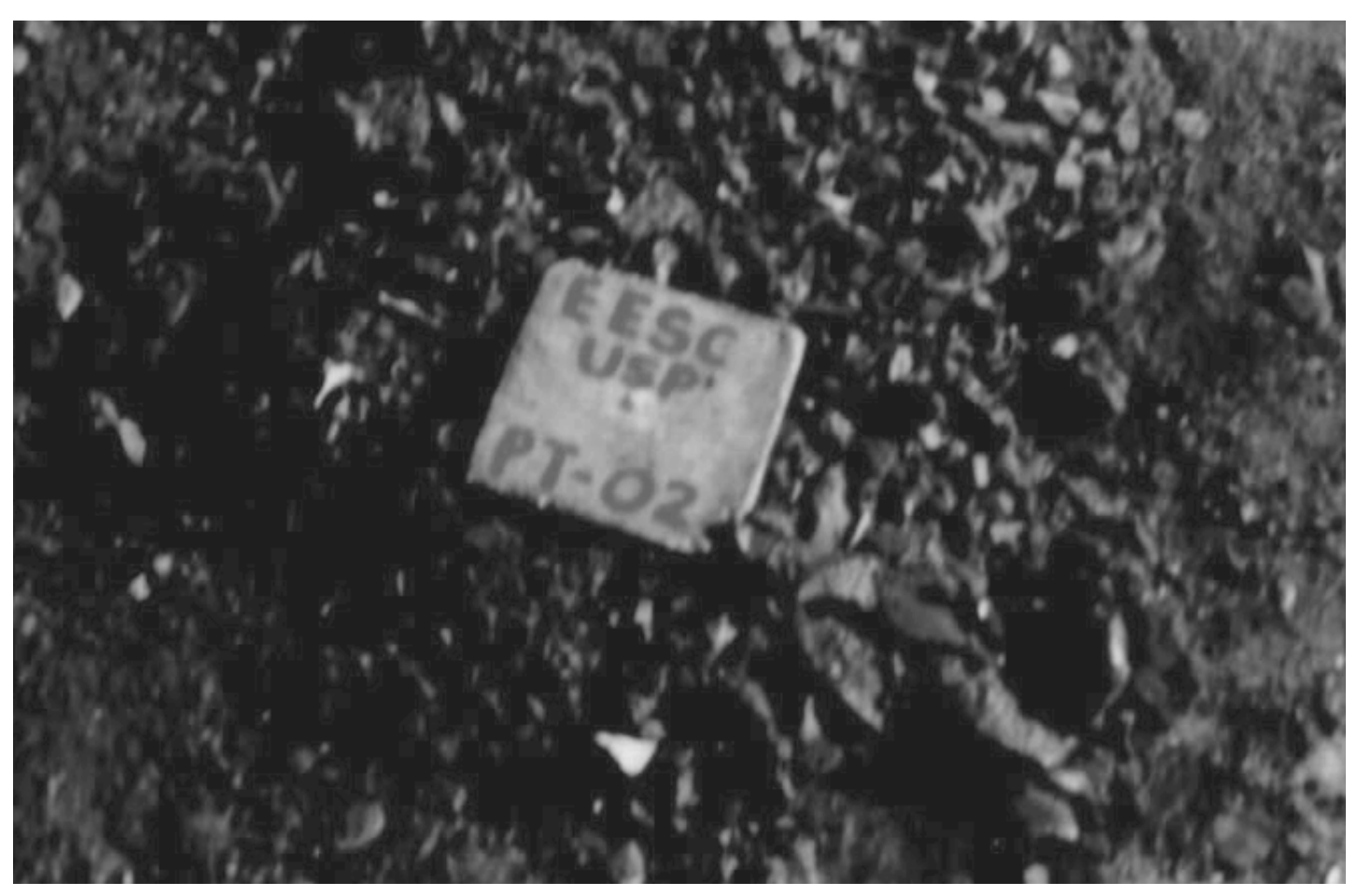

Figura 26 - Foto do Marco 


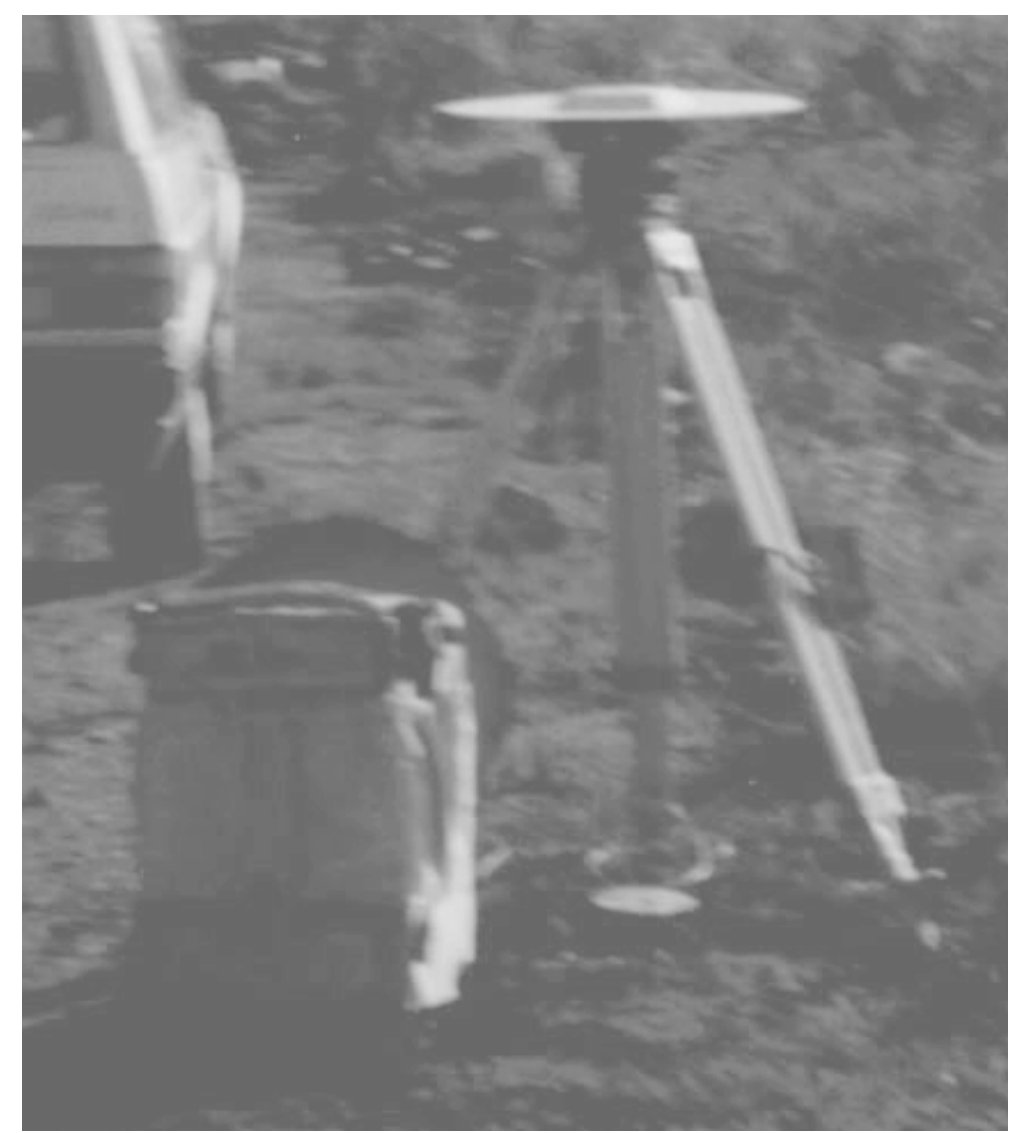

\section{Figura 27 - Equipamento da TRIMBLE 4000SST}

O segundo passo foi estabelecer as coordenadas dos demais marcos, estabelecendose um total de 7 linhas base ao longo do trecho pesquisado, tendo como ponto de referência o marco 1. O tempo de observação foi de 60 minutos para cada marco. Com todos os pontos determinados, foi realizado o levantamento cinemático.

\subsubsection{LEVANTAMENTO CINEMÁTICO}

O levantamento cinemático foi realizado com um equipamento da WILD SR 9400 (Figura 28) e foi dividido em duas etapas:

1. Na primeira etapa foram determinadas as coordenadas do trecho entre os marcos 1 e 4, sendo que o receptor estático ficou no marco 2 (Figura 29)

2. Na segunda etapa foram determinadas as coordenadas do trecho entre os marcos 4 e 8, sendo que o receptor estático ficou no marco 6 (Figura 30) 


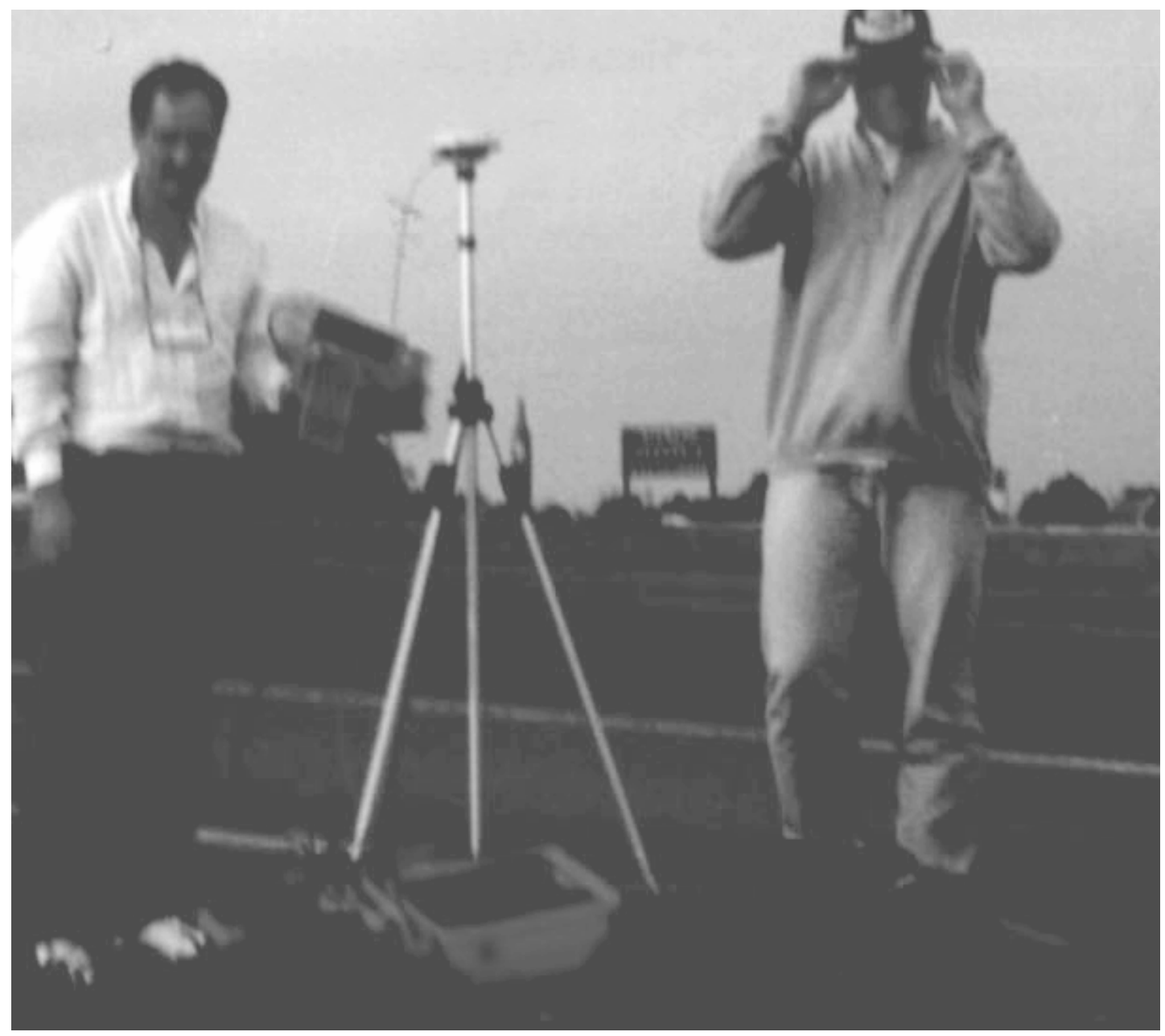

Figura 28 - Equipamento da Wild SR 9400

Na primeira etapa, o receptor móvel iniciou o trajeto a partir do marco 1 onde foi resolvida a ambigüidade, para isto, esse ficou no ponto por 15 minutos. Determinada a ambigüidade, o receptor móvel pode entrar em movimento. Aproximadamente a 3 Km do marco inicial, o receptor não conseguiu captar sinais de um número suficientes de satélites (>4) devido ao bloqueio do sinal por árvores que ficam bem próximas da rodovia, com isto finalizou-se esta etapa e em um ponto de coordenadas desconhecidas onde foi restabelecido o contato com mais de 4 satélites determinouse novamente a ambigüidade através do método rápido estático (PT11), permanecendo-se no ponto por 15 minutos. A indicação da WILD para determinar a ambigüidade é que em linhas bases conhecidas o tempo necessário é 5 épocas ou 5 
segundos e no caso de não se conhecer as coordenadas do ponto (método estático de resolução da ambigüidade) o tempo necessário é de 900 épocas ou 15 minutos. Devido à falta de disponibilidade de equipamento, julgou-se ser mais prudente durante o levantamento permanecer 15 minutos nos pontos de coordenadas conhecidas.

Depois de determinada a ambigüidade no ponto PT11, iniciou-se novamente o levantamento cinemático. Logo em seguida $(1 \mathrm{Km})$ o receptor não conseguiu captar os sinais de quatro de satélites (número mínimo recomendado), tendo que ser novamente determinada a ambigüidade. Como o receptor conseguiu captar os sinais de mais de quatro de satélites somente próximo do marco 2 , onde estava o outro receptor, o receptor móvel estacionou no ponto PT21 próximo deste marco. Após 15 minutos, o levantamento foi reinicializado. E após $3 \mathrm{~km}$ houve perda de ciclo novamente. A ambigüidade foi determinada no marco 3. Logo em seguida o receptor não conseguiu captar os sinais de quatro de satélites. Resolvida a ambigüidade no ponto PT31, as coordenadas do trecho entre este ponto até o marco 4 foram determinadas.

O grande problema deste trecho foram as árvores muito próximas da estrada que bloquearam os sinais dos satélites. Nos trechos onde não havia interferência, o receptor captou sinais de 6 a 7 satélites. O levantamento cinemático total durou 1 h e 24 min para esse trecho de cerca de $15 \mathrm{~km}$. 


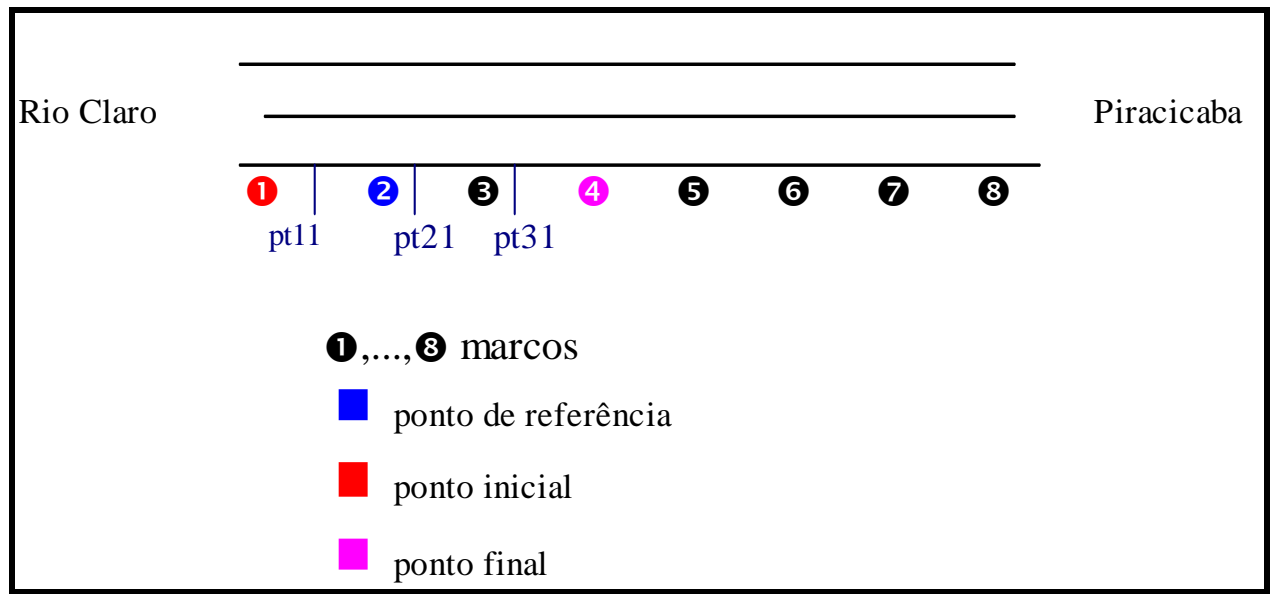

\section{Figura 29 - Primeira Etapa do Levantamento Cinemático}

Na segunda etapa do levantamento, o receptor estático foi deslocado para o marco 6 e foi levantado o trecho que vai do marco 4 ao marco 8 (Figura 30). Resolvida a ambigüidade no marco 4, o receptor móvel iniciou o levantamento que foi interrompida pela obstrução do sinal por um viaduto. Ultrapassado este obstáculo, determinou-se novamente a ambigüidade no ponto PT41, finalizando o levantamento próximo ao marco 8 . O tempo total gasto nesta etapa foi de 43 min para um trecho de cerca de $15 \mathrm{~km}$.

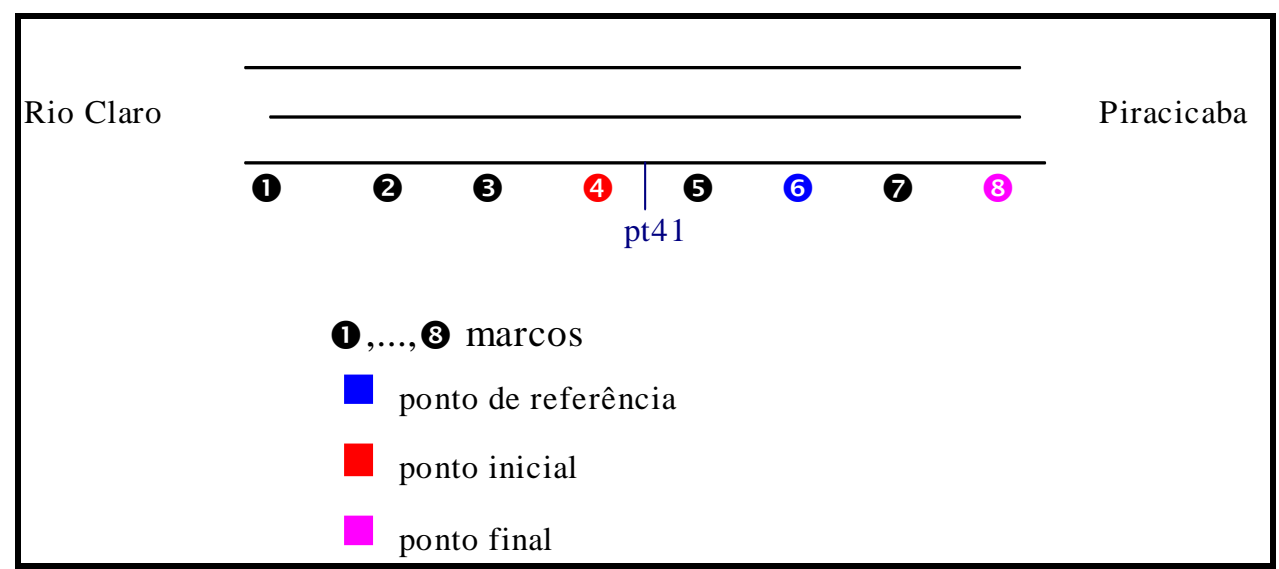

Figura 30 - Segunda Etapa do Levantamento Cinemático 
Todo o levantamento cinemático foi realizado sob escolta policial a uma velocidade de $40 \mathrm{~km} / \mathrm{h}$. Isto gerou uma pequena interferência no tráfego, não somente pela baixa velocidade, mas principalmente pela presença da polícia rodoviária.

O tempo total de observação, considerando o levantamento estático e cinemático, foi de aproximadamente $11 \mathrm{~h}$ e $40 \mathrm{~min}$, sendo que a maior parte pertence ao levantamento estático ( 9 h e 30 min de observação). O tempo total de todo o levantamento (incluindo deslocamento entre Rio Claro e São Carlos, deslocamento entre os marcos, instalação da antena, tempo de observação) foi de 4 dias. O levantamento em todos os dias começou às 7 horas e terminou no máximo às 18 horas.

No primeiro dia, foi determinado a coordenada do marco 1. Considerando a instalação da antena no marco da Universidade Federal e no marco 1, a viagens e o tempo de observação, o tempo gasto foi de 7 horas.

No segundo dia, foram determinadas as coordenadas de quatro marcos. Para cada marco, o tempo gasto foi de 2,5 horas (considerando o tempo de deslocamento, observação, instalação/retirada da antena). No terceiro dia foram determinadas, as coordenadas dos demais marcos.

Para todo o levantamento cinemático (incluindo instalação das antenas (móvel e fixa), transferência da antena fixa do marco 2 para o marco 6, tempo de observação e resolução da ambiguidade), o tempo gasto foi de aproximadamente 9 horas. 


\section{RESULTADOS}

Os dados do levantamento estático foram processados no software TRIMVEC 2.0 da TRIMBLE, o qual resultou em uma listagem contendo as coordenadas de cada ponto em coordenadas cartesianas e geodésicas e as informações relevantes referentes a precisão dos dados (Anexo A). O resultado do levantamento estático é apresentado na Tabela 9. Além das coordenadas geográficas dos oito marcos, são também apresentadas as coordenadas do marco da Universidade Federal de São Carlos.

Tabela 9 - Coordenadas dos Marcos em Coordenadas Geodésicas (WGS 84)

\begin{tabular}{|c|c|c|c|}
\hline Marco & Latitude & Longitude & Altura [m] \\
\hline $\begin{array}{l}\text { Universidade Federal de São } \\
\text { Carlos }\end{array}$ & $21^{\circ} 58^{\prime} 54.141968^{\prime \prime} \mathrm{S}$ & $47^{\circ} 52^{\prime} 44.295491^{\prime \prime} \mathrm{W}$ & 848.946 \\
\hline 1 & $22^{\circ} 26^{\prime} 14.404715^{\prime \prime} \mathrm{S}$ & $47^{\circ} 34^{\prime} 16.494544^{\prime \prime} \mathrm{W}$ & 597.864 \\
\hline 2 & $22^{\circ} 28^{\prime} 40.427505^{\prime \prime} \mathrm{S}$ & $47^{\circ} 34^{\prime} 45.629247^{\prime \prime} \mathrm{W}$ & 536.566 \\
\hline 3 & $22^{\circ} 30^{\prime} 35.643111^{\prime \prime} \mathrm{S}$ & $47^{\circ} 35^{\prime} 01.982998 ” \mathrm{~W}$ & 523.282 \\
\hline 4 & $22^{\circ} 33^{\prime} 29.460153^{\prime \prime} \mathrm{S}$ & $47^{\circ} 35^{\prime} 0.2523679 ” \mathrm{~W}$ & 622.043 \\
\hline 5 & $22^{\circ} 35^{\prime} 47.21297^{\prime \prime} \mathrm{S}$ & $47^{\circ} 35^{\prime} 36.99486 ” \mathrm{~W}$ & 574.990 \\
\hline 6 & $22^{\circ} 38^{\prime} 41.35415^{\prime \prime} \mathrm{S}$ & $47^{\circ} 36^{\prime} 21.07368^{\prime \prime} \mathrm{W}$ & 576.011 \\
\hline 7 & $22^{\circ} 40^{\prime} 20.375710^{\prime \prime} \mathrm{S}$ & $47^{\circ} 37^{\prime} 42.856752^{\prime \prime} \mathrm{W}$ & 562.788 \\
\hline 8 & $22^{\circ} 41^{\prime} 50.42433^{\prime \prime} \mathrm{S}$ & $47^{\circ} 39^{\prime} 09.67111$ ” W & 529.351 \\
\hline
\end{tabular}

Os dados do levantamento cinemático foram processados no sofware SKY da Empresa WILD do qual resulta um arquivo ASCII que lista os pontos e suas coordenadas geodésicas ou cartesianas e um arquivo contendo todas as informações sobre o levantamento (Anexo B). 
Este arquivo em ASCII pode ser lido no TRANSCAD, que converte um arquivo texto com os pontos em coordenadas geodésicas em um arquivo de pontos ou linhas. Mas, o arquivo que sai do SKY tem que ser um pouco alterado para se enquadrar nos padrões do arquivo de entrada do TRANSCAD. Estas alterações podem ser feitas rapidamente dentro do software EXCEL. A Tabela 10 mostra o formato do arquivo que gerou um arquivo de pontos (Figura 31). Para visualizar melhor como é apresentado o arquivo de pontos, foi dado um zoom no trecho próximo a Rio Claro (Figura 32). A Tabela 11 mostra o formato do a arquivo que gerou um arquivo de linhas (Figura 33). A Figura 34 apresenta um zoom do trecho inicial próximo a Rio Claro. As descontinuidades apresentadas nas figuras é devido o bloqueio do sinal pelas árvores próximas da rodovia. Desta forma não foi possível determinar as coordenadas de vários pontos nestes trechos.

Tabela 10 - Arquivo de Entrada do TRANSCAD Para Criar um Arquivo de Linhas

\footnotetext{
$1,2,-47.5710226,-22.43723292,-47.5712624,-22.43992038$, $2,2,-47.5712624,-22.43992038,-47.5712624,-22.43992038$, $3,2,-47.5712624,-22.43992038,-47.5712624,-22.43992038$, $4,2,-47.5712624,-22.43992038,-47.5712624,-22.43992038$, $5,2,-47.5712624,-22.43992038,-47.5712624,-22.43992038$, $6,2,-47.5712624,-22.43992038,-47.5712624,-22.43992038$, $7,2,-47.5712624,-22.43992038,-47.5712624,-22.43992038$, $8,2,-47.5712624,-22.43992038,-47.5712624,-22.43992038$, $9,2,-47.5712624,-22.43992038,-47.5712624,-22.43992038$, $10,2,-47.5712624,-22.43992038,-47.5712624,-22.43992038$, $11,2,-47.5712624,-22.43992038,-47.5714759,-22.44085388$, $12,2,-47.5714759,-22.44085388,-47.5714759,-22.44085388$, $13,2,-47.5714759,-22.44085388,-47.5714759,-22.44085388$, $14,2,-47.5714759,-22.44085388,-47.5714759,-22.44085388$,
}

\section{Tabela 11 - Arquivo de Entrada do TRANSCAD Para Criar um Arquivo de Pontos}

$1,-47.5710226,-22.43723292,563.1737$

$2,-47.5712624,-22.43992038,560.6296$

$3,-47.5712624,-22.43992038,560.6296$

$4,-47.5712624,-22.43992038,560.6296$

$5,-47.5712624,-22.43992038,560.6296$

$6,-47.5712624,-22.43992038,560.6296$

$7,-47.5712624,-22.43992038,560.6296$

$8,-47.5712624,-22.43992038,560.6296$

$9,-47.5712624,-22.43992038,560.6296$

$10,-47.5712624,-22.43992038,560.6296$

$11,-47.5712624,-22.43992038,560.6296$

$12,-47.5714759,-22.44085388,560.8565$

$13,-47.5714759,-22.44085388,560.8565$

$14,-47.5714759,-22.44085388,560.8565$ 


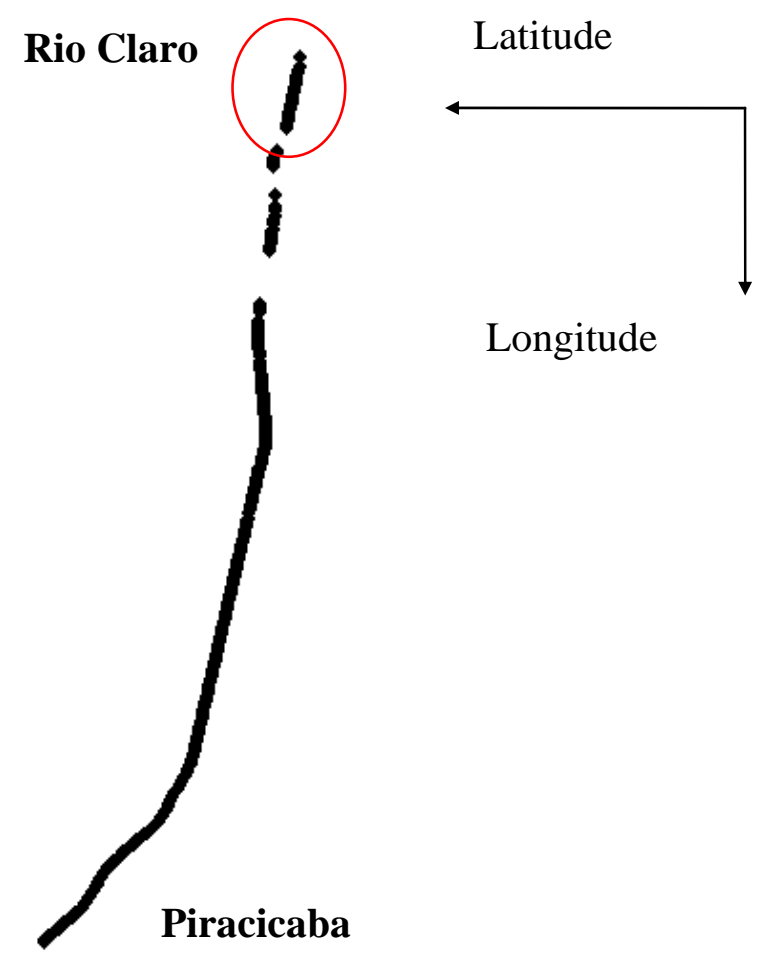

Figura 31- Representação Gráfica da Rodovia no Plano XY por um Arquivo de Pontos no TRANSCAD

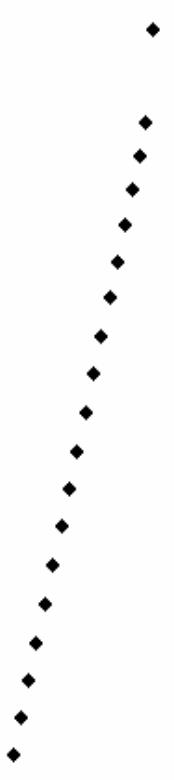

Figura 32 - Zoom do Trecho Inicial da Rodovia Próximo a Rio Claro 


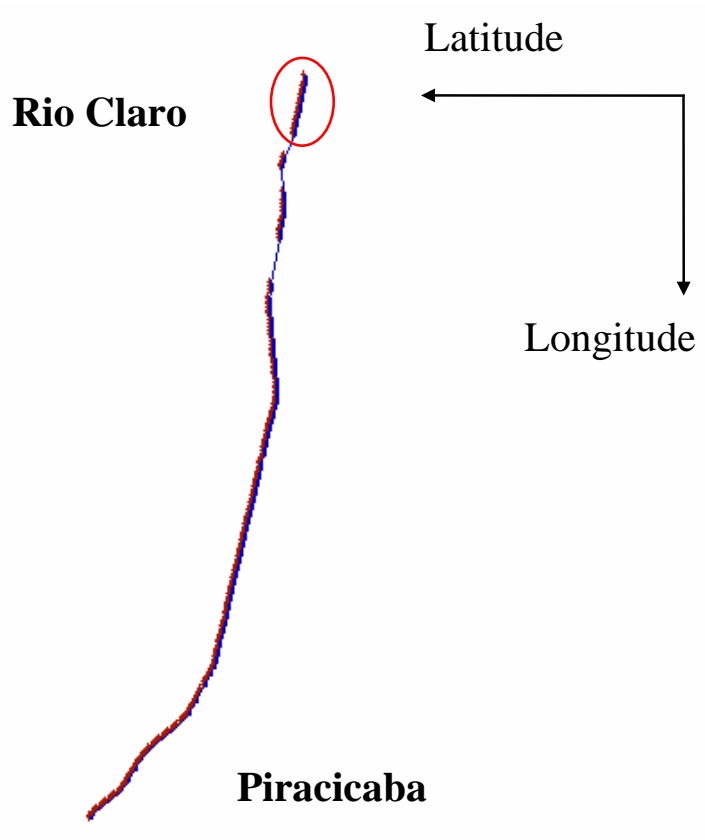

Figura 33 - Representação Gráfica da Rodovia no Plano XY por um Arquivo de Linhas no TRANSCAD

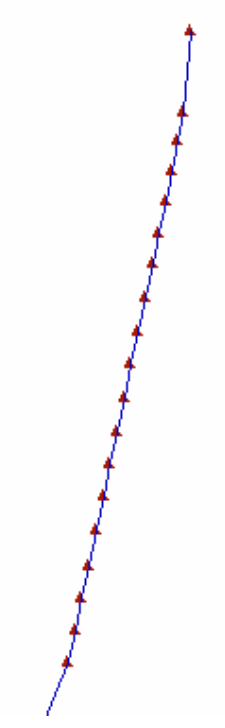

Figura 34 - Zoom do Trecho Inicial da Rodovia Próximo a Rio Claro 
O propósito de transferir os dados da geometria para o TRANSCAD é por ser este um Sistema de Informações Geográficas que possibilita armazenar, além dos dados referentes à geometria, outros dados importantes tais como: acidentes, condições do pavimento, sinalização, tráfego etc. Geralmente, estes dados são apresentados em função da quilometragem o que dificulta sua integração com os dados da geometria que estão em coordenadas geodésicas. No TRANSCAD é possível resolver este problema, pois ele transforma o quilômetro em coordenadas geodésicas, possibilitando assim unir os dois bancos de dados. Desta forma, o pesquisador, ao analisar os acidentes e as características geométricas, tem uma visão macroscópica do problema, podendo escolher os pontos críticos e os parâmetros a serem estudados rapidamente, sem precisar ir ao local. A existência do banco de dados reduz consideravelmente o tempo de coleta de dados, possibilitando que todos os esforços sejam direcionados ao estudo da relação entre a características geométricas e os acidentes.

Como o objetivo desta dissertação é apenas apresentar um método para criar a base geográfica do SIG, não foi realizada a união entre dados de acidentes (por exemplo) e os dados da geometria da rodovia.

No estudo da relação dos acidentes com a geometria da rodovia é necessário estabelecer a inclinação das rampas, raio das curvas verticais e horizontais, etc. No TRANSCAD não é possível determinar estes parâmetros. Para isto, foi escolhido o AUTOCAD, que é um software gráfico muito usado na engenharia civil e também por várias instituições ligadas a projeto de rodovias.

O AUTOCAD não importa diretamente um arquivo de pontos em ASCII, sendo necessário utilizar outros softwares que convertam um arquivo em ASCII em um arquivo gráfico. Isto é possível através do software LISCAD da Empresa WILD.

Antes de importar o arquivo de pontos para o LISCAD é necessário transformar as coordenadas geodésicas em coordenadas UTM. Esta transformação foi realizada dentro de uma planilha do EXCEL. Feita a transformação, foi possível representar 
graficamente o trecho da estrada pesquisado e exportá-lo para o AUTOCAD em três ou duas dimensões.

Através do AUTOCAD é possível visualizar a rodovia em planta (Figura 35) e perfil (Figura 36)

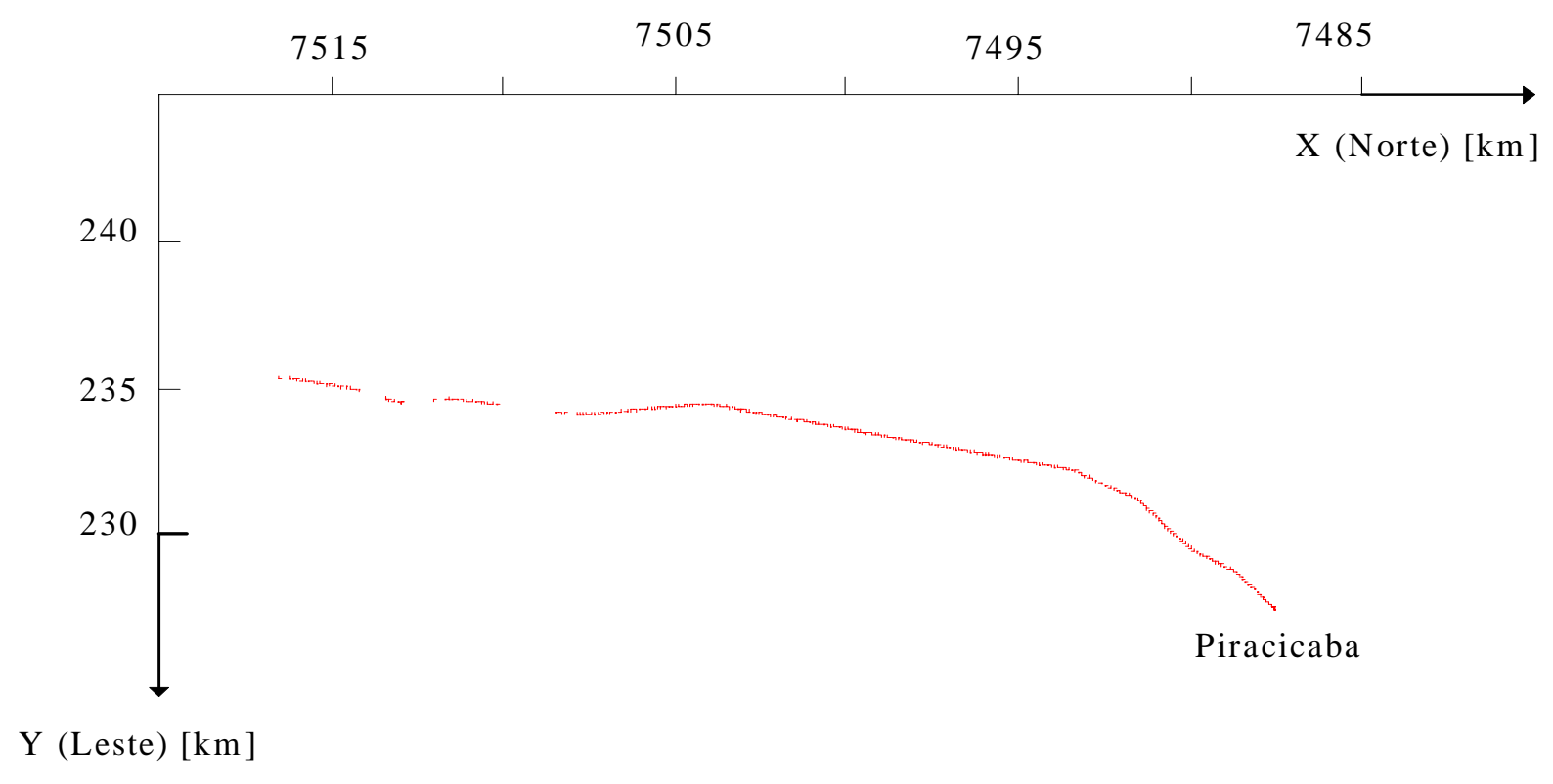

Figura 35 - Rodovia em Planta (Plano XY) em Coordenadas UTM

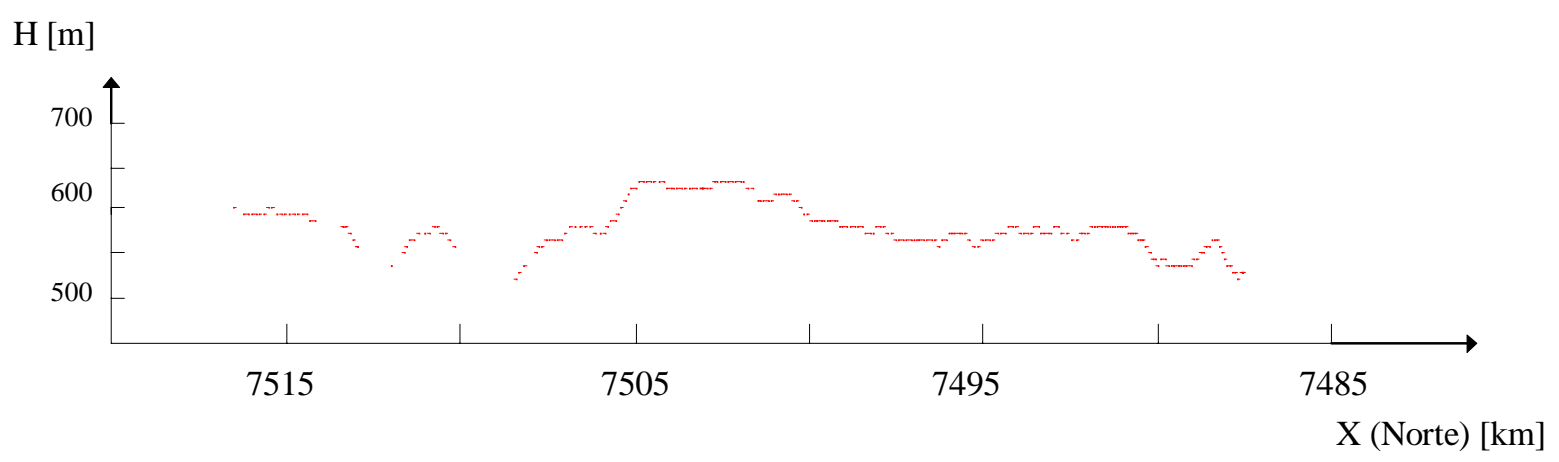

Figura 36 - Rodovia em Perfil (Plano XZ) em Coordenadas UTM 
Geralmente em projetos de rodovias, a escala horizontal da projeção XZ é 10 vezes menor que a escala vertical para facilitar a visualização do perfil da estrada. Como não foi possível apresentar uma rodovia de $33 \mathrm{~km}$ dentro do espaço disponível com a escala usual de projetos, adotou-se uma escala vertical 50 vezes maior que a escala horizontal.

A partir destas projeções consegue-se redesenhar aproximadamente a rodovia da forma em que foi construída e também obter uma estimativa dos raios das curvas horizontais (sem considerar o trecho de transição) e das curvas verticais, bem como o comprimento das tangentes. Para mostrar o método proposto e avaliar os erros cometidos na determinação de valores de raios de curvas horizontais e verticais e de inclinações e comprimentos de rampas foram desenvolvidos três exemplos ilustrativos dos problemas associados a medições a partir de projeções no AUTOCAD.

\section{Exemplo 1 - Raios de Curvas Horizontais}

Para detalhar a geometria horizontal da estrada é possível simplesmente ampliar os trechos desejados no AUTOCAD e determinar os raio da curva diretamente com os recursos desse software, conforme é mostrado no exemplo 1. Nas Figuras 37 e 38 é apresentada a localização em planta e perfil da curva horizontal cujo raio será determinado pelo AUTOCAD. 


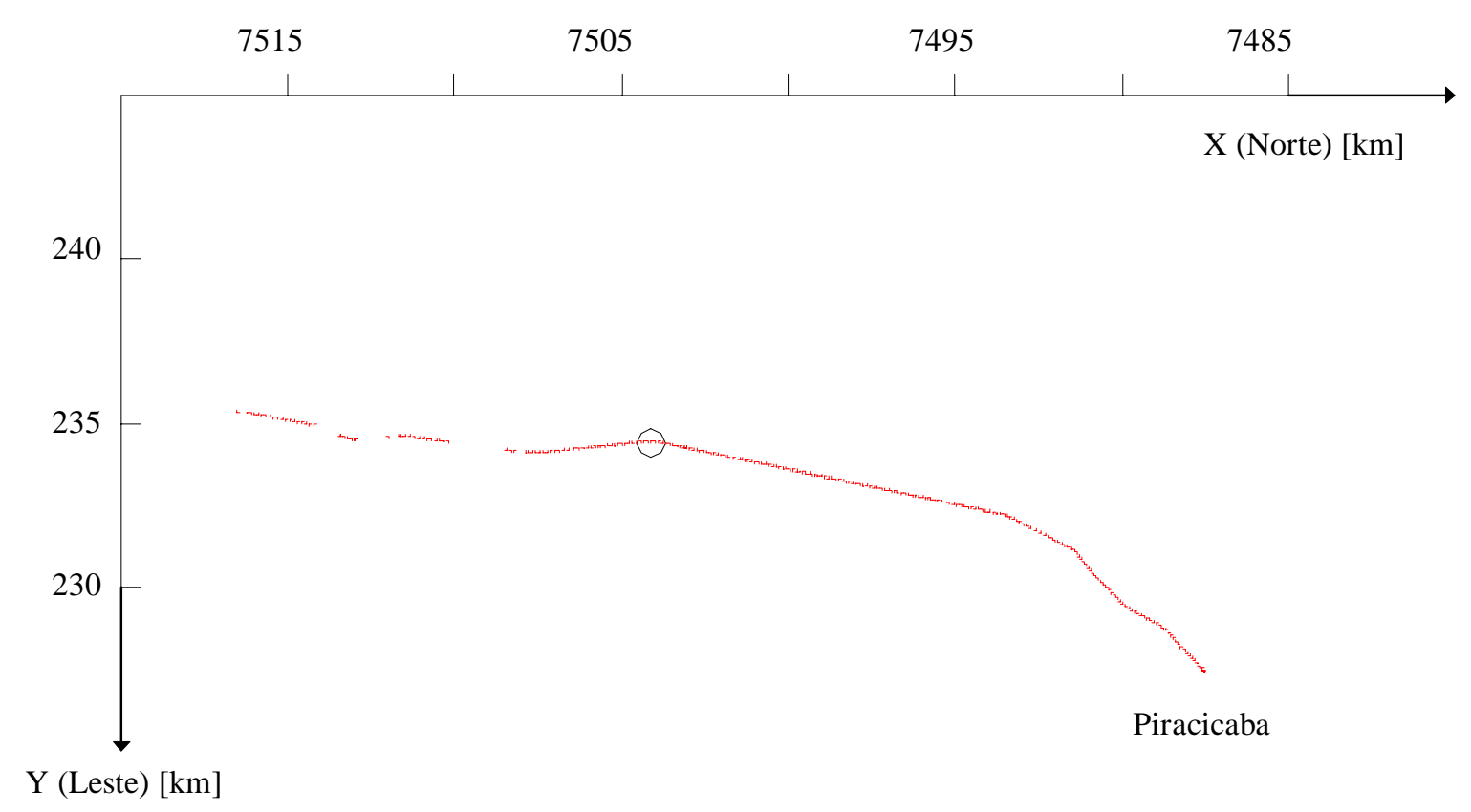

Figura 37 - Localização em Planta do Exemplo 1 (Coordenadas UTM)

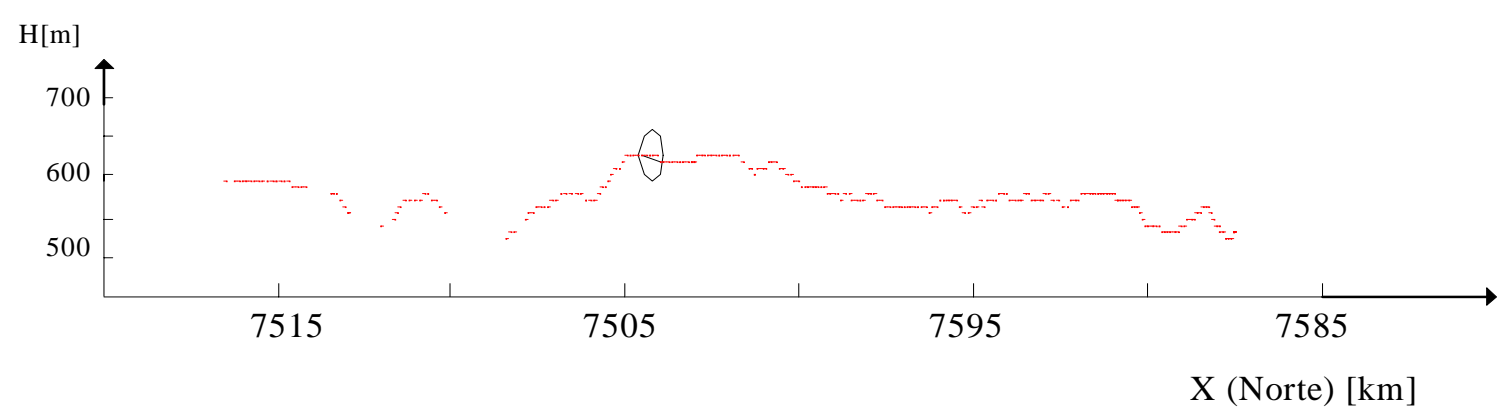

Figura 38 - Localização do Exemplo 1 no Perfil da Estrada (Coordenadas UTM) 


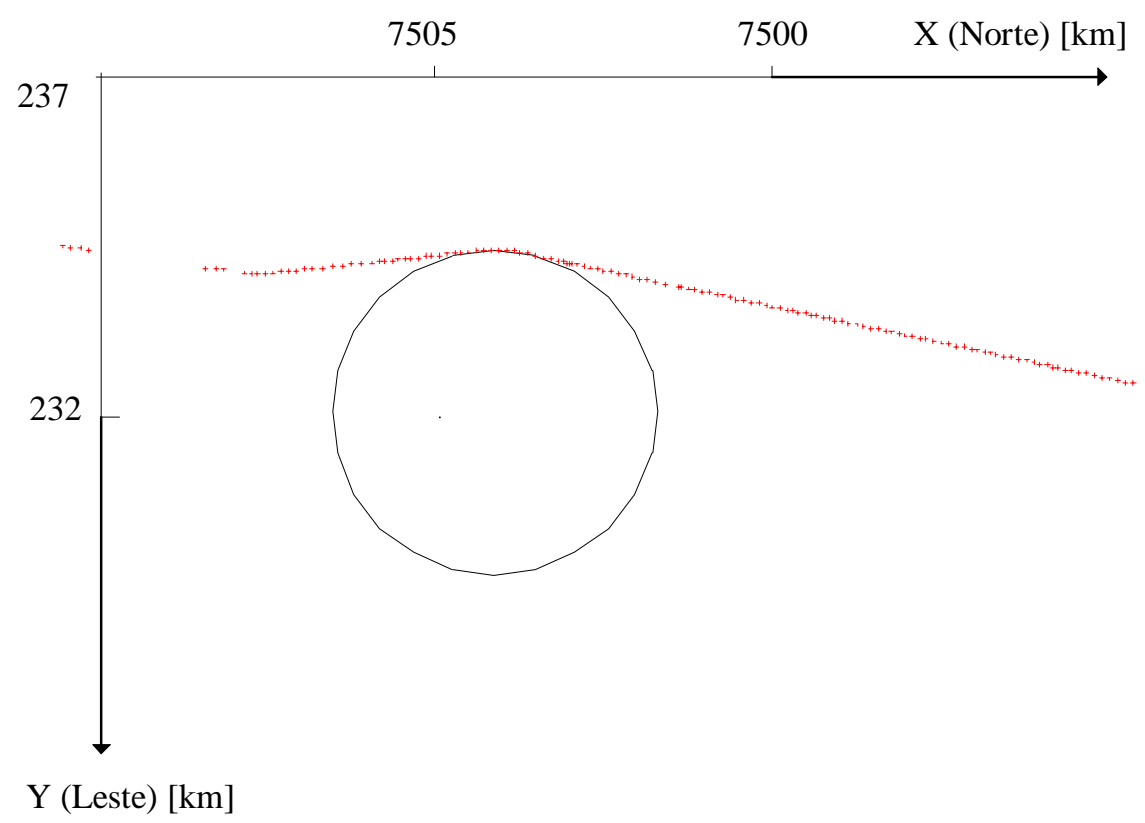

Figura 39 - Raio da Curva Horizontal do Exemplo 1 Obtido através do AUTOCAD (Coordenadas UTM)

O valor obtido pela rotina interna do AUTOCAD para o raio da curva foi de $2250 \mathrm{~m}$. Para verificar o resultado obtido pelo AUTOCAD, determinou-se analiticamente o raio da curva horizontal do exemplo 1 através da equação da circunferência. Três pontos da curva são necessários para se resolver três equações que têm como incógnitas as coordenadas do centro da curva e o raio.

$$
(\mathrm{X}-\mathrm{Xc})^{2}+(\mathrm{Y}-\mathrm{Yc})^{2}=\mathrm{R}^{2}
$$

onde $\mathrm{X}$ - abcissa de um ponto da circunferência

Y - ordenada de um ponto da circunferência

Xc - abcissa do centro da circunferência

Yc - ordenada do centro da circunferência

$\mathrm{R}$ - raio da circunferência 
Desenvolvendo a equação obtém-se:

$$
\mathrm{X}^{2}+\mathrm{Y}^{2}-2 * \mathrm{X}^{*} \mathrm{Xc}-2 * \mathrm{Y}^{*} \mathrm{Yc}+\mathrm{Xc}^{2}+\mathrm{Yc}^{2}=\mathrm{R}^{2}
$$

Esta equação pode ser apresentada da seguinte forma:

$$
\mathrm{AX}^{2}+\mathrm{BY}^{2}-\mathrm{CX}-\mathrm{DY}+\mathrm{E}=0
$$

onde $\mathrm{A}=1$

$$
\begin{aligned}
& \mathrm{B}=1 \\
& \mathrm{C}=-2 * \mathrm{Xc} \\
& \mathrm{D}=-2 * \mathrm{Yc} \\
& \mathrm{E}=\mathrm{Xc}^{2}+\mathrm{Yc}^{2}-\mathrm{R}^{2}
\end{aligned}
$$

Determinando as incógnitas C, D e E determina-se os parâmetros desejados para a representação da curva horizontal. E o valor do raio obtido desta maneira para o exemplo 1 foi de $2350 \mathrm{~m}$. Portanto, a diferença entre os raios é de $100 \mathrm{~m}$, ou seja de 4,25 \%. Para o estudo da relação de acidentes e a geometria, este erro pode ser considerado pequeno. No caso de projeto geométrico, dois fatores limitam os valores mínimos dos raios a serem adotados (PIMENTA, 1981) :

- estabilidade dos veículos que percorrem a curva com grande velocidade,

- mínimas condições de visibilidade.

No caso de distância mínima de visibilidade, a visibilidade deverá ser verificada em função dos obstáculos, ou no caso de curvas dentro de cortes em função da posição e inclinação dos taludes. Para isto. determina-se a distância entre o eixo da pista e o obstáculo ou talude (M). Sendo que a condição mínima de visibilidade é definida por (PIMENTA, 1981):

$$
M \geq R *\left(1-\cos \left(\frac{D f}{2 * R}\right)\right)
$$

onde $R$ - raio da curva em $\mathrm{m}$ 
Df - distância de frenagem (PIMENTA, 1981)

$$
D f=0,69 * V+0,0039 * \frac{V^{2}}{f \pm i}
$$

onde: $V$ - velocidade diretriz em $\mathrm{km} / \mathrm{h}$

$f$ - coeficiente de atrito

$i$ - inclinação longitudinal do trecho

Adotando-se $\mathrm{V}=80 \mathrm{~km} / \mathrm{h}, \mathrm{f}=0,30$ e sendo $\mathrm{i}=-0,87$ \%, a distância de frenagem será de $141 \mathrm{~m}$. Desta forma:

$\mathrm{M}=1,057 \mathrm{~m}$ (para o raio de $2350 \mathrm{~m}$ obtido pela fórmula da circunferência)

$\mathrm{M}=1,104 \mathrm{~m}$ (para o raio de $2250 \mathrm{~m}$ obtido pelo AUTOCAD)

O erro manteve-se em torno dos 4,2\%. Como o valor da distância entre o eixo e o obstáculo é obtido na planta, um erro de $5 \mathrm{~cm}$ na determinação do valor mínimo é desprezível. Portanto, neste caso errar 100 m no raio não interfere na decisão do analista.

Com relação a estabilidade do veículo, o menor raio a ser adotado considerando que o veículo está na iminência do escorregamento é dado pela seguinte equação (PIMENTA, 1981):

$$
R \min =\frac{V^{2}}{g *\left(e_{\max }+f_{\max }\right)}
$$

onde: $V$ - velocidade diretriz

$e_{\text {max }}$ - máximo valor da superelevação

$f_{\max }$ - máximo valor do coeficiente de atrito lateral

Adotando $\mathrm{V}=80 \mathrm{~km} / \mathrm{h}, \mathrm{e}_{\max }=0,012$ (segundo a AASHTO) e $\mathrm{f}_{\max }=0.14$ (segundo a AASHTO) encontrou-se Rmin igual a $332 \mathrm{~m}$. Como os valores obtidos por estes dois 
métodos são bem superiores a este valor, a diferença de 100 m não produz nenhum efeito na avaliação da curva com relação à estabilidade.

\section{Exemplo 2 - Representação do Perfil em um Trecho Reto}

Para representar o perfil na forma em que foi construído é necessário que a abcissa do gráfico represente o desenvolvimento do traçado. O AUTOCAD só representa corretamente o perfil em trechos retos e fornece uma aproximação razoável se as curvas horizontais têm raios grandes. Em ambos os casos isto só acontece se a estrada estiver alinhada com o eixo $\mathrm{x}$ do sistema de coordenadas. Portanto, a projeção XZ do estudo de caso sem rotação do eixo x, é apenas uma aproximação grosseira do perfil da rodovia apresentada nas Figuras 36 e 38.

Uma solução exata para determinar o perfil da rodovia é desenhar as altitudes versus a quilometragem da rodovia. Portanto, é necessário importar um arquivo para o AUTOCAD onde a abcissa do gráfico representa o desenvolvimento do traçado horizontal da rodovia e a ordenada as altitudes correspondentes dos pontos. Entretanto, não é possível importar um arquivo desta natureza no LISCAD sendo consequentemente impossível exportá-lo do LISCAD para o AUTOCAD conforme foi feito anteriormente. Uma possível solução é criar um programa dentro do AUTOCAD através do AUTOLISP que possibilite importar os dados da maneira desejada. Outra solução é explorar outros softwares gráficos específicos para projetos de rodovia. Dadas as limitações do escopo desta pesquisa estas possíveis soluções não foram exploradas. Um caminho alternativo para representar o perfil foi o de utilizar os recursos computacionais da planilha EXCEL da Microsoft, que permite uma rápida transformação das coordenadas XY no desenvolvimento do traçado. 
A técnica adotada utiliza as coordenadas dos pontos em coordenadas cartesianas e calcula as distâncias espaciais entre eles, admitindo-se que para os intervalos de tempo

entre medidas sucessivas do GPS percorre-se um trecho reto. A visão geral da rodovia em perfil é mostrada na Figura 40 (onde H é a altura geométrica).

Mais uma vez utilizou-se uma escala com distorção bem maior que a utilizada convencionalmente no projeto de rodovias para ilustrar os resultados do método. No caso da planilha EXCEL, o ajuste de escala vertical e horizontal é difícil, mas os cálculos de rampas e raios de curvas são obtidos com grande facilidade.

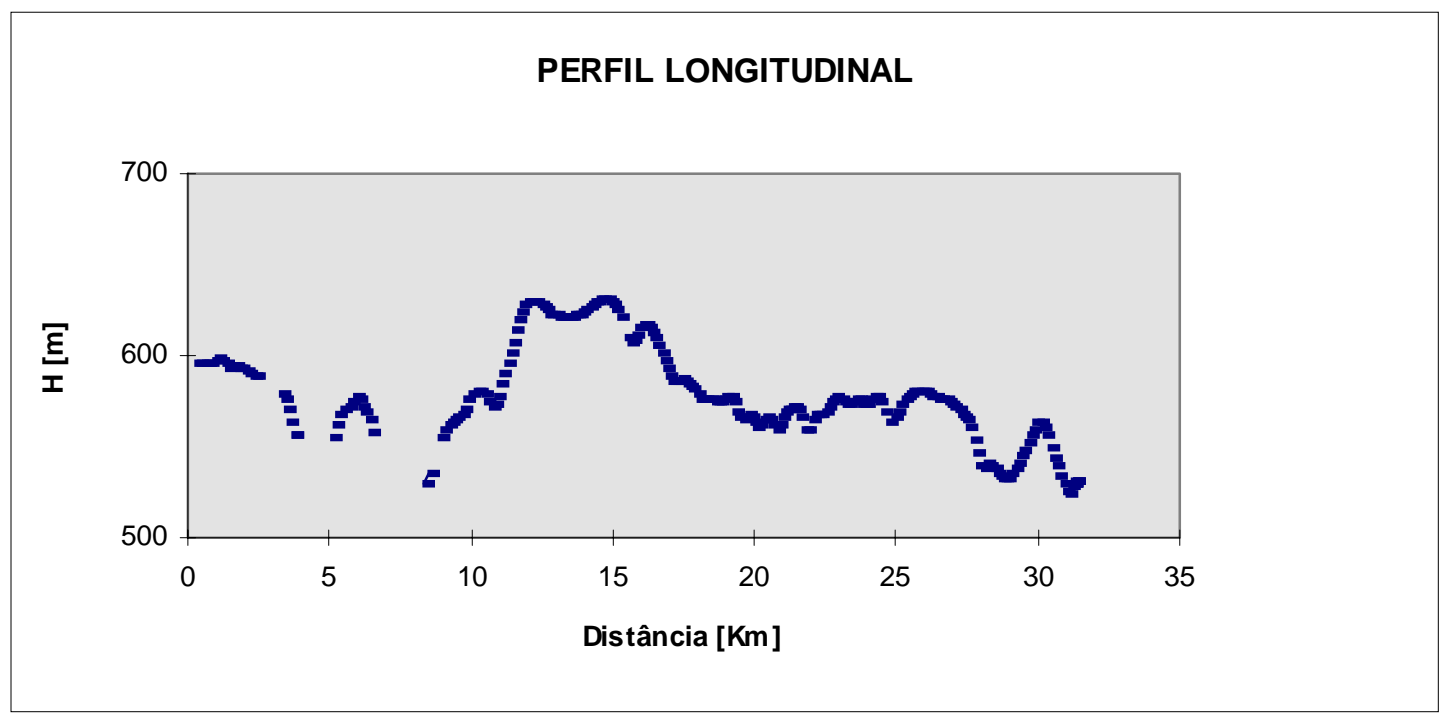

Figura 40 - Perfil Longitudinal da Rodovia Obtido Através do EXCEL

O raio é determinado através da equação de uma circunferência, conforme foi descrito anteriormente na determinação analítica da curva horizontal.

Para exemplificar a diferença entre a solução exata (planilha do EXCEL) e a estimativa grosseira obtida no AUTOCAD na determinação do raio de uma curva vertical, calculou-se o raio de uma curva vertical em um trecho sem curva horizontal 
(exemplo 2). A localização em planta e perfil do exemplo 2 é mostrada nas Figuras 41 e 42.

A ampliação da curva vertical do exemplo 2 mostrada na Figura 44 permite o ajuste de uma circunferência, apenas de forma visual, aos segmentos de reta que resultam da projeção XZ no AUTOCAD.

Como para este software, a circunferência é uma entidade bidimensional, ou seja só pode ser definida no plano XY, não é possível determinar o raio que melhor se ajusta mediante a escolha de três pontos da curva vertical. A solução encontrada foi desenhar a circunferência no plano XY, rotacioná-la de $90^{\circ}$ e modificar o seu raio até que se consiga ajustá-la à curva vertical. O raio obtido por este método gráfico aproximado para o exemplo 2 na Figura 43 é de 3500 m

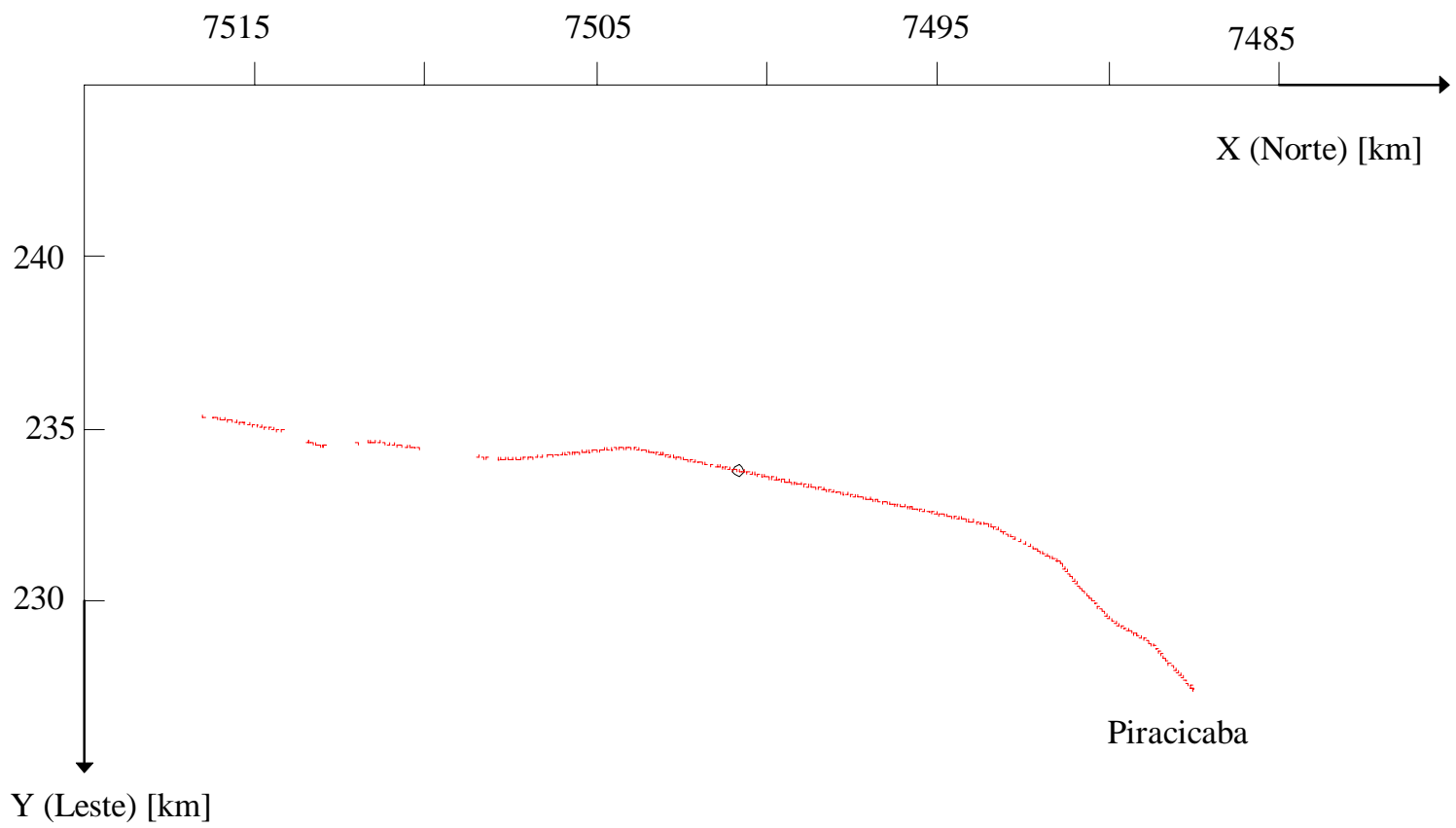

Figura 41 - Localização da Curva Vertical do Exemplo 2 em Planta (Coordenadas UTM) 


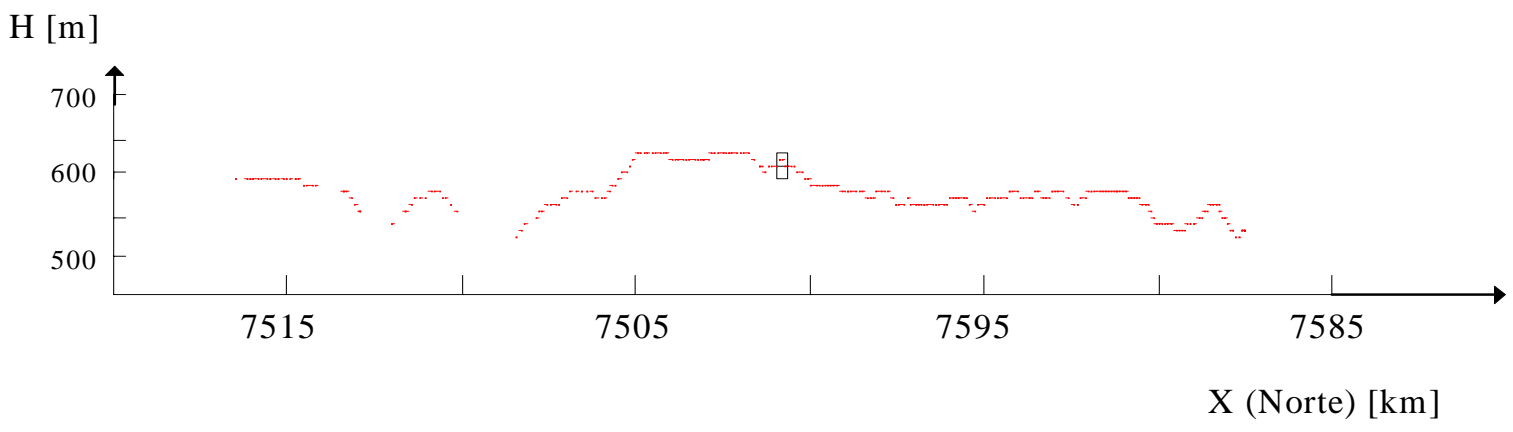

Figura 42 - Localização da Curva Vertical do Exemplo 2 em Perfil (Coordenadas UTM)

Figura 43 - Curva Vertical do Exemplo 2 no AUTOCAD

Para avaliar o grau de erro associado ao método gráfico do AUTOCAD o raio da curva vertical foi calculado através da planilha EXCEL e obteve-se o valor de 6066 m (Figura 44). Portanto, a diferença entre os valores obtidos é de $42 \%$. Para o estudo da relação entre os acidentes e a geometria da rodovia esta diferença é alta. Na curva vertical uma precisão maior é importante pois, ela afeta de forma direta a distância de visibilidade e portanto tem influência direta também sobre os requisitos de sinalização horizontal de proibições de ultrapassagem. Além disso, condições de conforto e boa aparência da curva são normalmente alcançadas quando a curva atende às condições mínimas de visibilidade (PIMENTA, 1981). Estas condições mínimas de visibilidade dependem da distância mínima de frenagem e esta é utilizada para determinar o comprimento mínimo de uma curva vertical. 


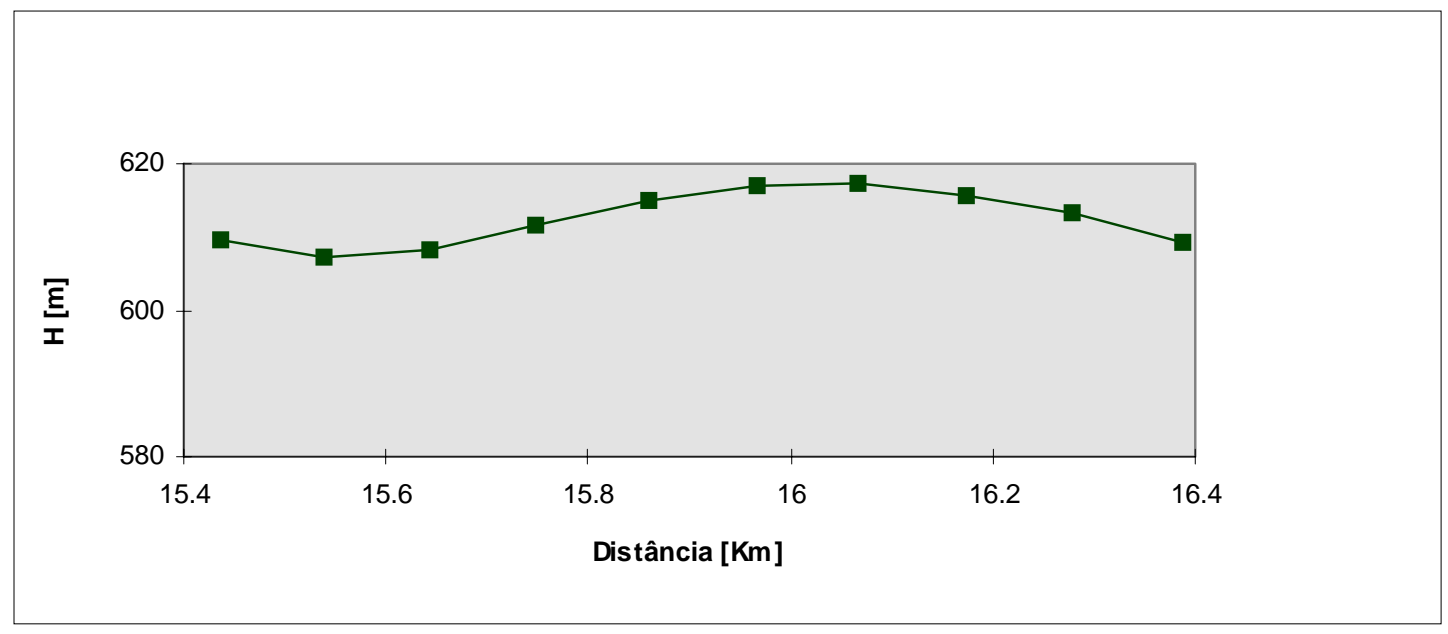

Figura 44 - Curva Vertical do Exemplo 2 no EXCEL

Como o ajuste do raio no AUTOCAD é uma questão visual, esta solução pode ser melhorada através de uma estimativa do raio através da equação da circunferência passando por três pontos selecionados da curva vertical. O raio desta curva determinado pela equação da circunferência é igual a $5800 \mathrm{~m}$. Nota-se que o valor do erro diminui para 4,4\%. Ajustando-se a curva vertical dentro de AUTOCAD com este valor, pode-se analisar o resultado através da Figura 45 onde a curva de $3500 \mathrm{~m}$ e esta de 5800 m estão superpostas. Portanto, a diferença visual entre a primeira solução $(\mathrm{R}=3500)$ e a segunda solução $(\mathrm{R}=5800)$ é pequena, mas conduz a interpretações da geometria da via diferentes em termos de distância de visibilidade.

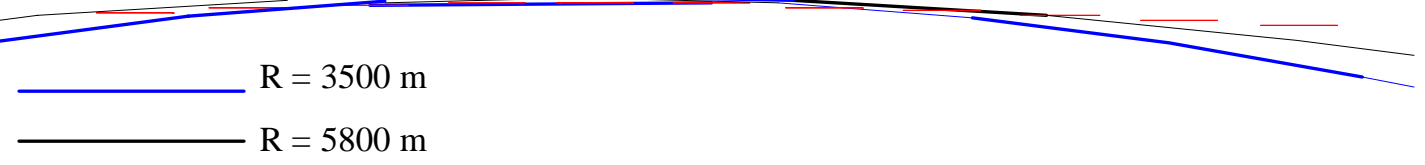

Figura 45 - Superposição das Duas Soluções do Exemplo 2 no AUTOCAD

Para o caso de curvas convexas, o comprimento mínimo da curva vertical (Lv) é dado através de um ábaco (Figura 10 página 22, PIMENTA (1981)) em função da diferença algébrica dos greides das rampas e da velocidade de projeto ou distância de 
frenagem. No exemplo 2, a diferença algébrica das rampas $\left(\delta_{\mathrm{i}}\right)$ é de aproximadamente 6,1 \% onde a inclinação da rampa anterior a curva é de $+3,1 \%$ e a da posterior é de -3\% (estes valores foram determinados através da planilha EXCEL). Adotando-se uma velocidade de projeto de $80 \mathrm{~km} / \mathrm{h}$, encontrou-se um Lc $c_{\text {mín. de }} 170 \mathrm{~m}$.

Calculando os comprimentos das curvas das duas soluções no AUTOCAD, os valores obtidos são: 210 m para $R=3500 \mathrm{~m}$ e $248 \mathrm{~m}$ para $\mathrm{R}=5800 \mathrm{~m}$. Os dois valores estão acima do valor mínimo, mas o comprimento da primeira solução está bem próximo do valor mínimo, o que poderia sugerir uma mudança do raio para o analista.

Um segundo aspecto importante que precisa ser resolvido é o do alinhamento da estrada com o sistema de coordenadas. Quanto mais alinhada estiver a estrada com o eixo x, mais próxima da solução exata estará a solução obtida com o AUTOCAD. Analisando esta hipótese, alinhou-se o trecho reto, onde se localiza o exemplo 2, com o eixo x através de uma rotação de $12^{\circ}$ (Figura 46). Cabe observar que o módulo de X’Y’é diferente do módulo de XY.

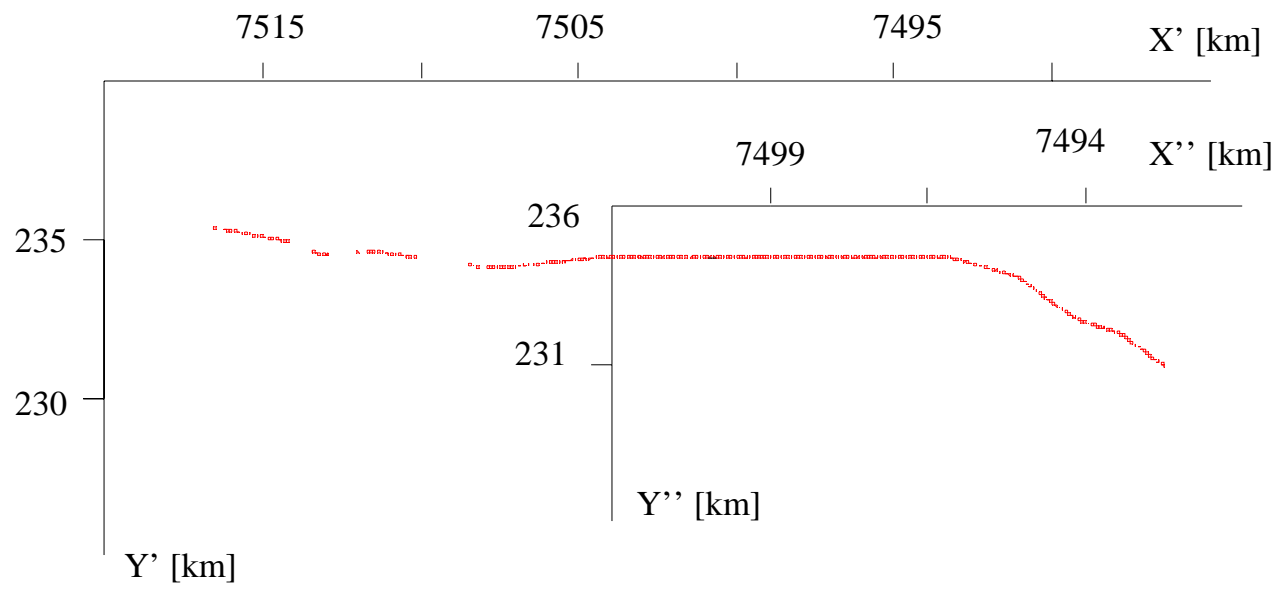

Figura 46 - Trecho Reto Rotacionado de $12^{\circ}$ (Coordenadas UTM) 
Como no AUTOCAD, a precisão do ajuste visual é pequena, antes de tentar ajustar um raio, procurou-se ter uma estimativa do raio através da equação da circunferência como foi feito anteriormente, obtendo-se o valor de $6069 \mathrm{~m}$. Como era de se esperar, este valor está bem próximo da solução exata sendo o erro 0,1%.

Um estudo análogo pode ser realizado com relação à inclinação das rampas. Determinou-se a inclinação das rampas anterior e posterior à curva vertical do exemplo 2. O valor exato determinado através da planilha EXCEL é de 3,1\% para a rampa anterior e de $3 \%$ para a rampa posterior. No AUTOCAD a inclinação destas rampas antes do trecho rotacionado é de 3,2 \% para a rampa anterior e de 3,1\% para a rampa posterior, sendo o erro, neste caso em torno de 3\%. Este erro diminui para aproximadamente $0 \%$ quando se compara o valor exato com o resultado obtido depois do alinhamento.

Portanto, para o caso do exemplo 2, o alinhamento da rodovia com o eixo x faz com que a solução do AUTOCAD aproxime-se satisfatoriamente da solução exata.

\section{Exemplo 3 - Representação do Perfil em um Trecho Curvo}

Para analisar a influência da curva horizontal na caracterização da curva vertical apresenta-se o exemplo 3, onde se escolheu o trecho curvo cuja localização é mostrada na Figura 47. 


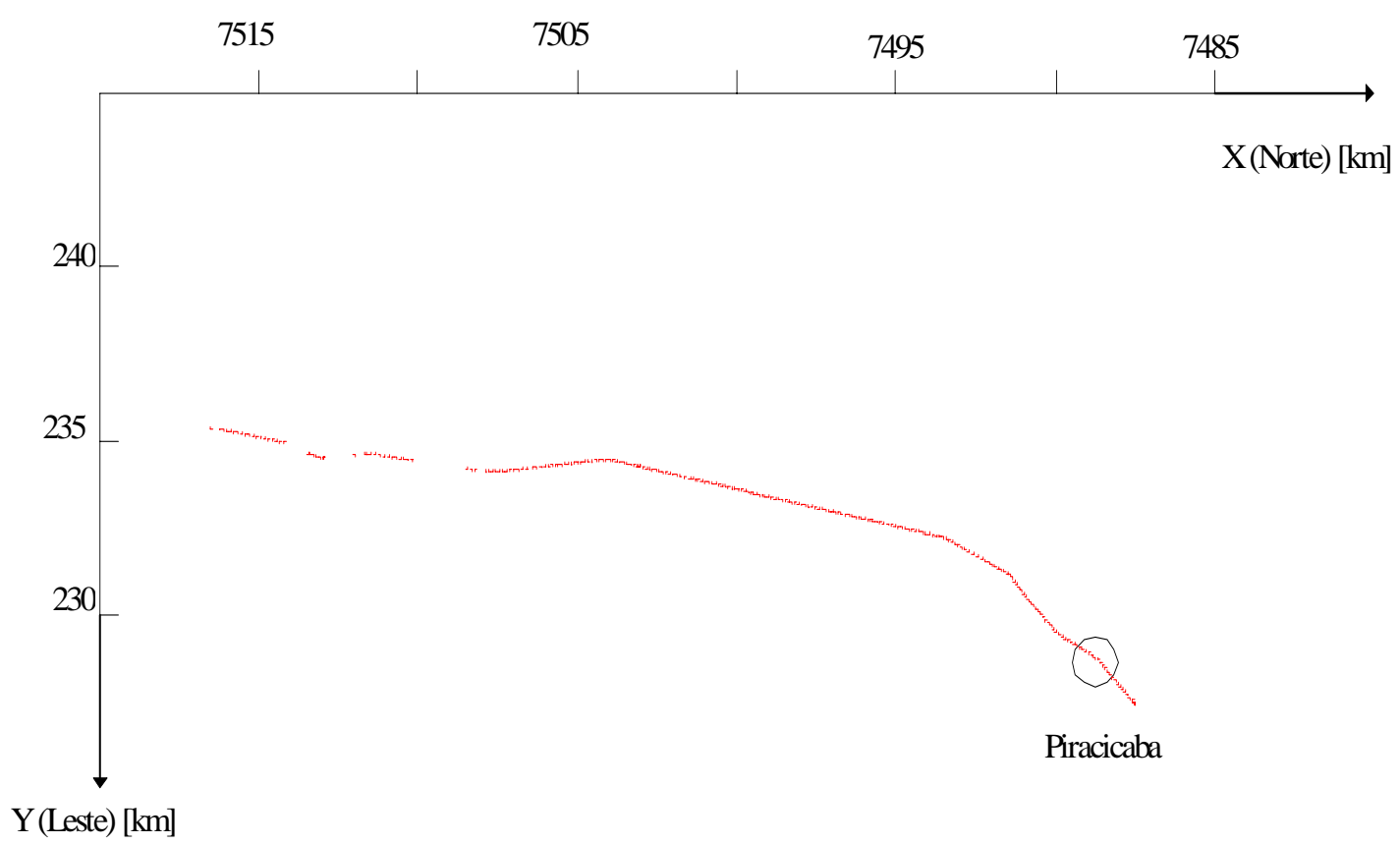

Figura 47 - Localização da Curva Horizontal do Exemplo 3 em Planta (Coordenadas UTM)

Para analisar a geometria horizontal ampliou-se o trecho conforme mostrado na Figura 48. 


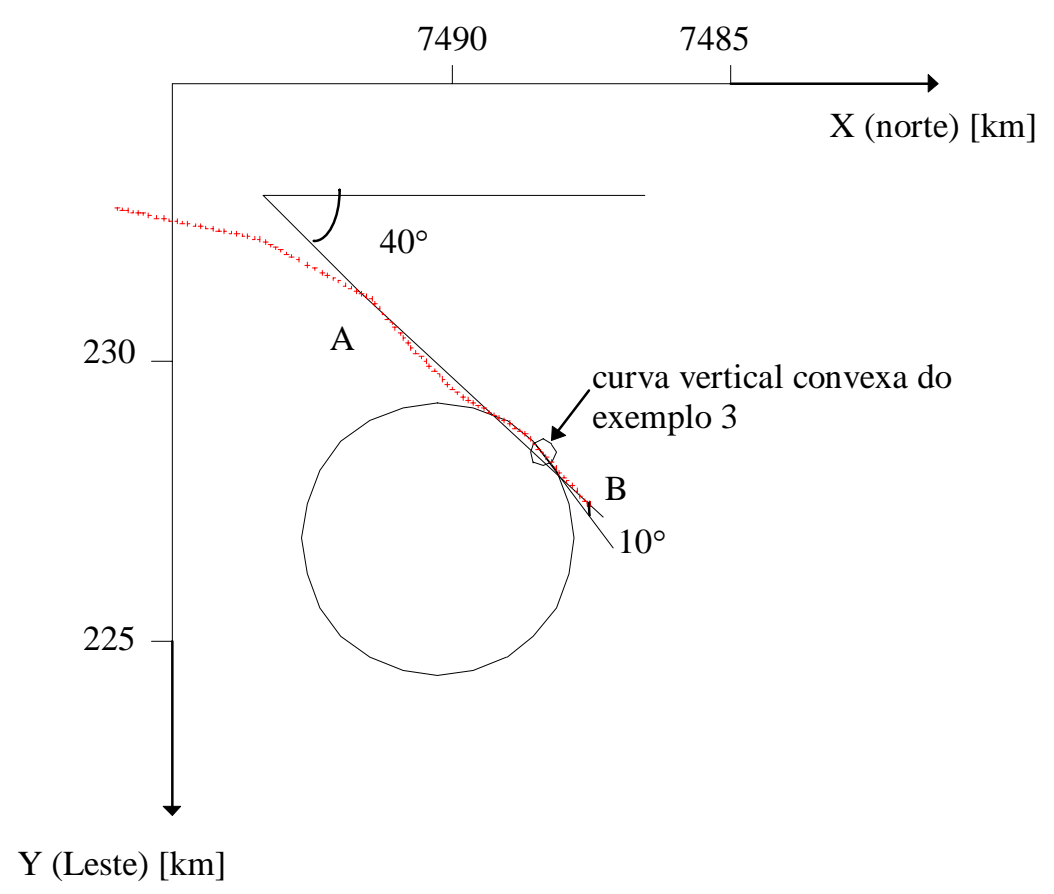

Figura 48 - Ampliação da Curva Horizontal do Exemplo 3 (Coordenadas UTM)

O raio da curva horizontal obtido através do ajuste do AUTOCAD foi de $2445 \mathrm{~m}$. Conforme foi realizado no exemplo 1, determinou-se o raio da curva horizontal do exemplo 3 através da equação da circunferência e obteve-se um raio de $2450 \mathrm{~m}$. Neste exemplo, o erro de 0,20 \% pode ser considerado desprezível.

A Figura 48 mostra também que o trecho tem uma rotação em relação ao sistema de coordenadas XY de $40^{\circ}$. A Figura 49 mostra o perfil do trecho em curva no sistema de coordenadas XZ original do AUTOCAD. 


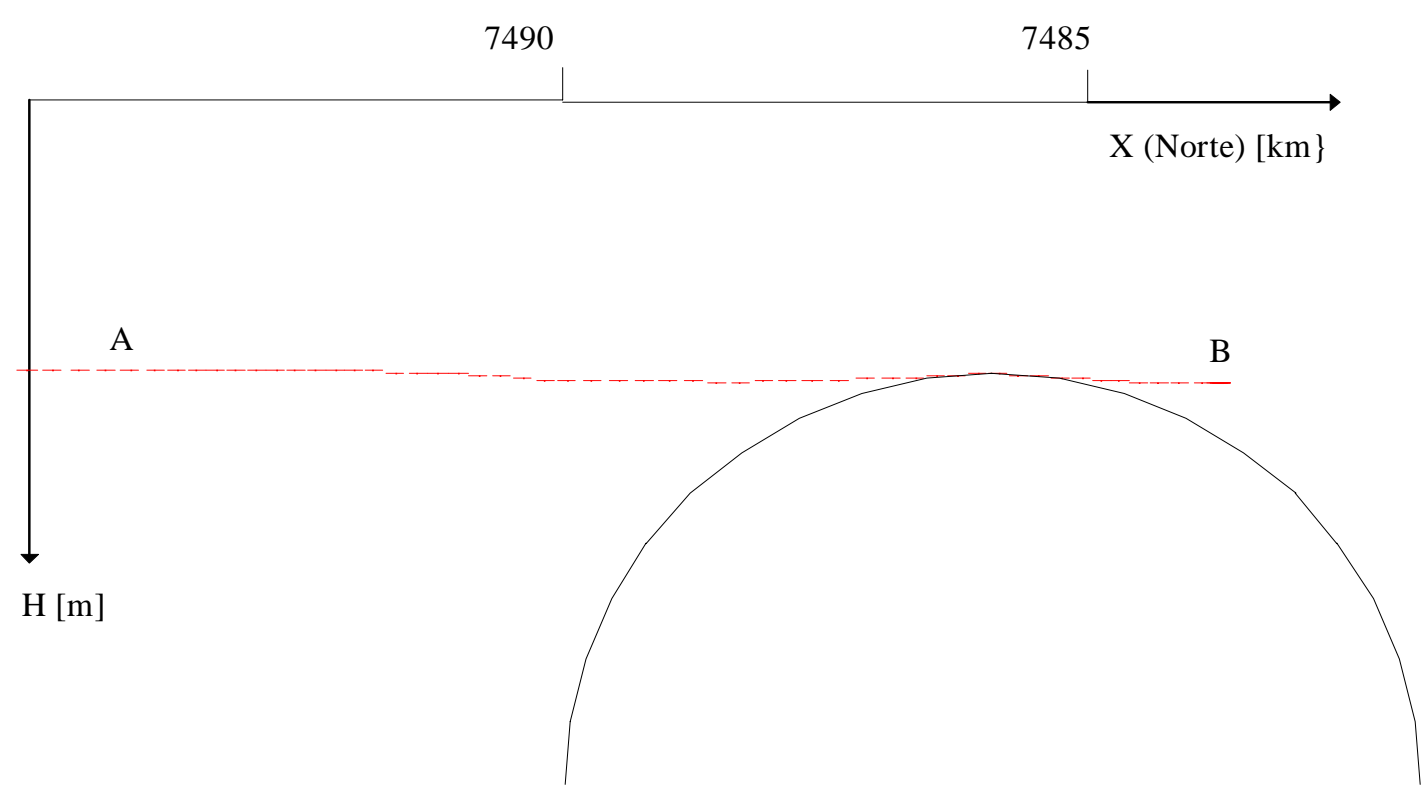

Figura 49 - Curva Vertical do Segmento AB Determinada Através do AUTOCAD (Coordenadas UTM)

O valor do raio da curva vertical obtido através da equação da circunferência com três pontos da Figura do AUTOCAD é de $2212 \mathrm{~m}$ e pela planilha EXCEL (solução exata) é de 5018 m (Figura 50). A diferença entre os valores obtidos é de 56\%. Mostra-se, neste caso, que para uma rotação da estrada de $40^{\circ}$ em relação ao sistema de coordenadas do AUTOCAD, o erro introduzido é bastante grande.

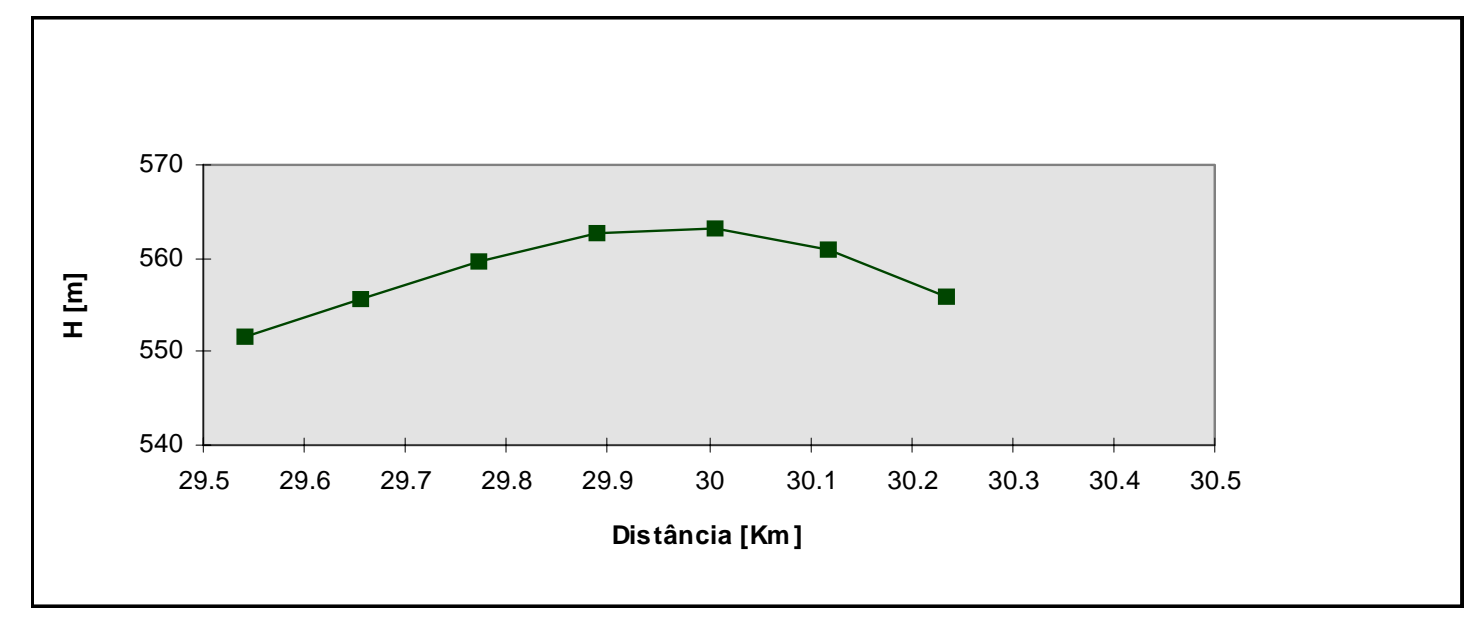

Figura 50- Curva Vertical Exata do Exemplo 3 no EXCEL 
A Figura 51 apresenta o trecho $\mathrm{AB}$ rotacionando-se o eixo x de $40^{\circ}$ e admitindo-se que o trecho $\mathrm{AB}$ é reto.

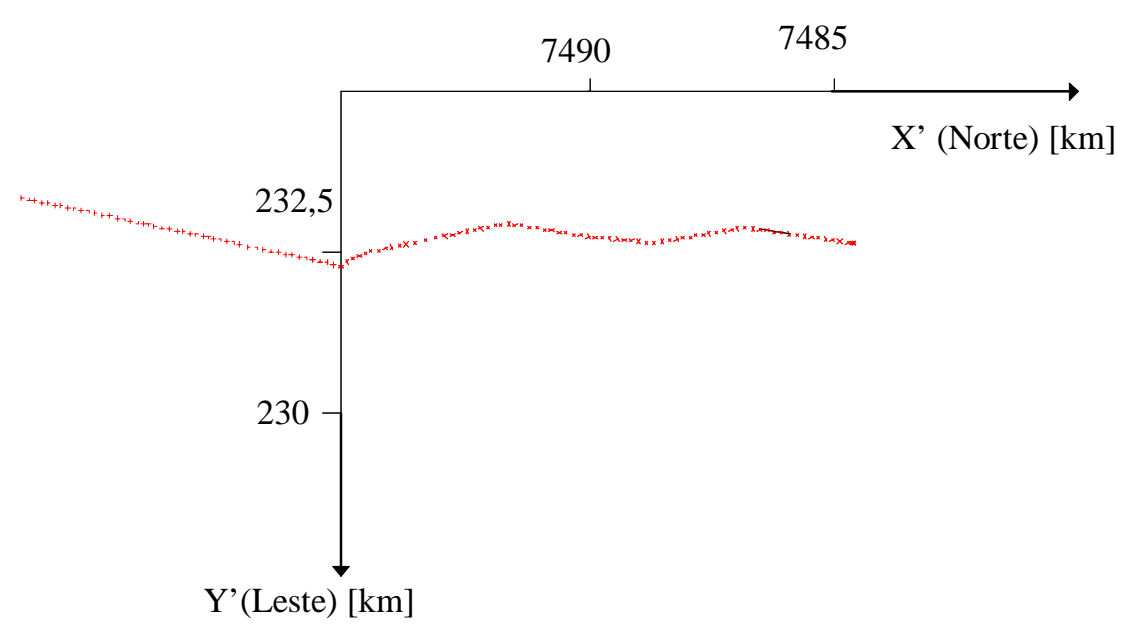

Figura 51 - Trecho Rotacionado de $40^{\circ}$ (Coordenadas UTM)

O valor do raio da curva vertical obtido através da equação da circunferência com três pontos da figura no AUTOCAD é de 4910 m. O erro desta solução comparandoa com a solução exata é de 2,1\%.

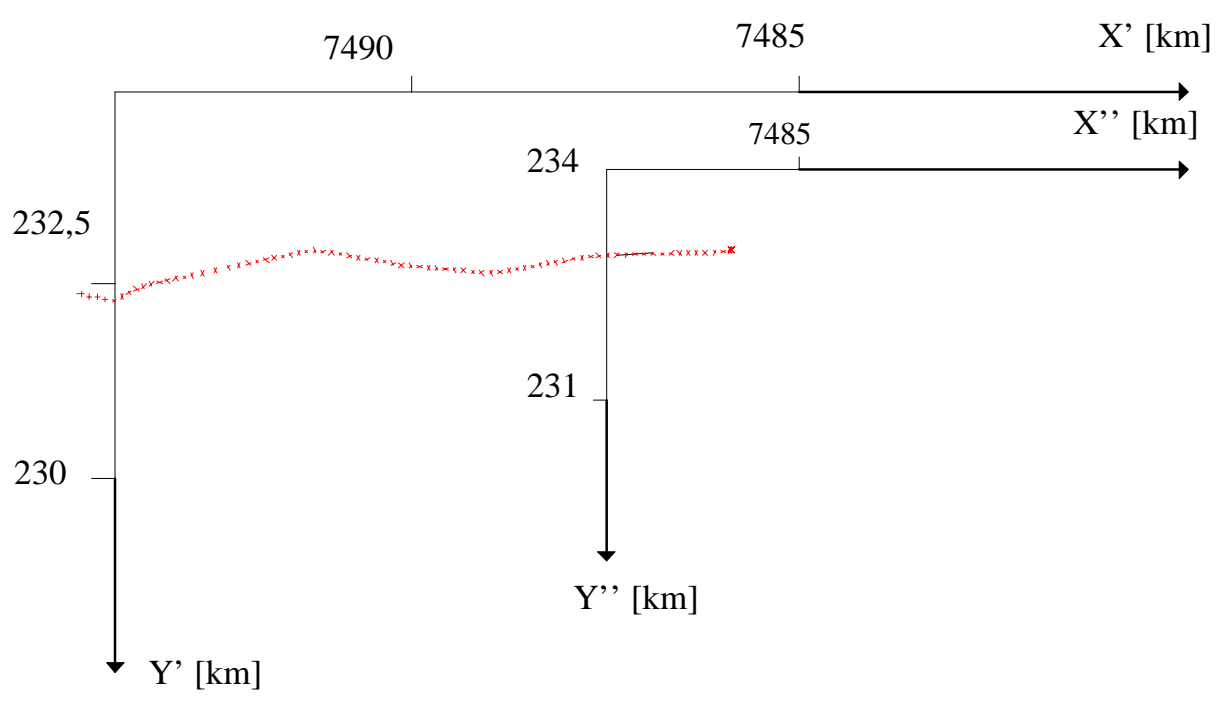

Figura 52 - Trecho Rotacionado de $10^{\circ}$ (Coordenadas UTM) 
Entretanto, a curva vertical do exemplo 3 não coincide com o PV da curva horizontal, na realidade ela está no segundo segmento da curva horizontal, portanto após o PV. Uma forma de melhorar a aproximação é rotacionar a rodovia para alinhá-la de forma mais precisa com o eixo x. Conforme pode ser observado na Figura 51, este procedimento requer uma rotação complementar de $10^{\circ}$. Efetuando-se essa rotação complementar no AUTOCAD (Figura 52) e calculando-se o raio da curva vertical pela equação da circunferência obtém-se o valor de 5014 m.

Obtém-se, portanto, através do método gráfico um valor praticamente igual ao valor exato de $5018 \mathrm{~m}$, com um erro de 0,36 \%.

Analisando o método gráfico para o caso da determinação da inclinação das rampas anterior e posterior à curva do exemplo 3, nota-se que o alinhamento da rodovia com o eixo x forneceu uma precisão razoável. O valor exato determinado através da planilha EXCEL é de $-5,3 \%$ para a rampa posterior e de $+3,4 \%$ para a rampa anterior. Antes da rotação da rodovia, o erro estava em torno de 50 \% (a inclinação da rampa posterior era de $-7,9 \%$ e da rampa anterior era de $+5 \%$ ). O alinhamento da rodovia com o eixo $x$, ou seja a rotação de $50^{\circ}$, reduziu este erro para aproximadamente $0 \%$. 


\section{CONCLUSÕES E SUGESTÕES}

\subsection{CONCLUSÕES}

O método proposto para o levantamento da seção longitudinal em planta e perfil de uma rodovia através do método cinemático utilizando o Sistema de Posicionamento Global, apesar do tempo necessário para resolver a ambigüidade durante o trajeto, mostrou ser um método rápido e promissor como base geográfica para um SIG de uma rede rodoviária.

O tempo total de observação, considerando o levantamento estático e cinemático, foi de aproximadamente $11 \mathrm{~h}$ e $40 \mathrm{~min}$, sendo que a maior parte pertence ao levantamento estático ( 9 h e 30 min de observação). Este tempo pode ser abolido a partir do momento que se utilize um equipamento GPS que resolva a ambigüidade durante o trajeto, o que também permitirá uma redução razoável de tempo de observação cinemático.

A utilização de um equipamento GPS integrado com um Sistema Inercial de Navegação (INS) resolveria, não somente o problema da ambigüidade, mas também permitiria estabelecer com precisão as coordenadas dos pontos nos locais onde o sinal foi bloqueado pelas árvores e pelo viaduto. Desta forma, o perfil longitudinal poderia ser apresentado sem falhas. 
Como os resultados são fornecidos em um arquivo em ASCII, a importação para outros softwares é agilizada, possibilitando ao pesquisador ter uma visão geral do trecho em duas e três dimensões.

Com estes dados no TRANSCAD, pode-se uni-los com os dados dos acidentes e visualizar os locais de maior índice de acidentes. Caso seja desejável ter uma visão em três dimensões destes locais, pode-se utilizar o AUTOCAD para apresentar o trecho crítico.

Através do AUTOCAD é possível desenhar a rodovia em planta e perfil com apenas algumas ressalvas. A determinação do raio das curvas horizontais através dos recursos gráficos do AUTOCAD apresenta uma precisão satisfatória quando comparada com os parâmetros de verificação das condições mínimas de visibilidade e escorregamento.

Quanto ao perfil da rodovia, a solução exata seria obtida através do gráfico de quilometragem versus altitude. Mas, um arquivo deste tipo não é possível ser importado através do LISCAD para o AUTOCAD. Uma solução imediata é utilizar a planilha EXCEL.

Comparando os resultados obtidos em um exemplo para determinar o raio da curva vertical pelo AUTOCAD e pelo EXCEL (solução exata), a diferença encontrada foi significante (acima de 40\%). Em alguns casos, esta diferença pode diminuir quando se faz uma estimativa do raio através da equação da circunferência que passa por três pontos da curva vertical, melhorando-se desta o ajuste visual. Portanto, outra limitação do AUTOCAD é a questão do ajuste visual.

Em outros casos, os resultados podem ser melhorados com o alinhamento da estrada com o eixo x. A solução gráfica obtida para os dois exemplos ficou muito próxima da solução exata (planilha EXCEL). 
Este método auxilia o analista de projetos na escolha dos locais com maior índice de acidentes e após o estudo da relação dos acidentes com a geometria da rodovia, na escolha de qual medida a ser tomada e qual é o custo/benefício de cada uma. Desta forma, será possível alocar os recursos públicos corretamente. Mas, os resultados encontrados neste método não possuem precisão suficiente para elaboração do projeto final e alocação na estrada.

\subsection{SUGESTÕES}

Com este trabalho, concretizou-se um método de obtenção do banco de dados referentes as características do projeto geométrico de uma rodovia. A complementação deste banco de dados englobaria a caracterização de todas as interseções existentes considerando não somente o entroncamento, mas também um pequeno trecho da rodovia, ou estrada vicinal, que a intercepta. Desta forma, o analista poderá ter uma visão global do que acontece nestas interseções em termos de comportamento do motorista ao se defrontar com condições geométricas que reduzam a visibilidade, dificultam a frenagem, etc.

Para completar os dados dos elementos do projeto geométrico, a determinação da superelevação e da largura da rodovia é necessária. Esses dados auxiliariam também no estudo de acidentes, para determinar sua influência nos conflitos entre os veículos e a resistência ao escorregamento e tombamento.

As reações dos motoristas não estão somente condicionadas à influência dos parâmetros do projeto geométrico, mas também sofrem a influência da sinalização vertical e horizontal, condições do pavimento, drenagem deficiente e outros. O levantamento dessas características pode ser realizado durante o levantamento cinemático, podendo-se obter a localização das placas existentes e o início e término de faixas de ultrapassagem proibida, por exemplo. 
Durante o levantamento cinemático do estudo de caso, alguns trechos não foram levantados devido à obstrução do sinal dos satélites pelas árvores. Estes lapsos podem ser determinados através de métodos convencionais com a utilização de uma Estação Total, ou através da integração do sistema GPS com um Sistema Inercial (INS). Desta forma nos locais onde o GPS não funciona, o INS entra em ação e a ambigüidade pode ser resolvida durante o trajeto. A realização do levantamento desta rodovia com um sistema integrado GPS/INS seria uma sugestão para averiguar a exequibilidade desta união.

Outra sugestão é utilizar um equipamento GPS que resolve a ambigüidade “on-thefly”, eliminando a necessidade de se estabelecer as coordenadas de pontos ao longo da estrada através do método estático, o que agilizaria o levantamento. Levantandose trechos acima de $10 \mathrm{~km}$, deve-se tomar cuidado com a diferença entre as alturas geoidais e elipsoidas e a influência da ionosfera e troposfera.

A união dos dados dos elementos geométricos e dos acidentes auxiliará na identificação da influência da geometria como fator contribuinte dos acidentes. Com estes dados pode ser realizado uma análise estatística para estabelecer a relação entre os acidentes e a geometria da rodovia, o qual poderá fornecer as sugestões de medidas a serem tomadas para melhorar a segurança nas rodovias existentes e os novos valores para o projeto geométrico das novas rodovias.

A caracterização do perfil longitudinal e transversal da rodovia também auxilia o estudo do desempenho dos veículos e a compatibilidade destes com as rodovias, principalmente dos veículos de carga, e tem influência direta no estudo da capacidade das rodovias. 
Com relação à caracterização da rodovia em planta e perfil é necessário elaborar um programa em AUTOLISP que possibilite desenhar o perfil da rodovia baseado no desenvolvimento da rodovia através do arquivo em ASCII fornecido pelo GPS. Também pode ser estudada a utilização de um outro software específico para projetos de rodovias que permita importar dados do GPS.

A união dos dados sobre os acidentes, perfil transversal e longitudinal, sinalização e também de tráfego em um Sistema de Informação Geográfica (SIG), auxiliará as autoridades na tomada de decisões. Poderá ser um grande passo para o estabelecimento de um programa mais eficaz de manutenção de rodovia, em termos da relação benefício/custo das intervenções possíveis com determinada verba.

A integração do SIG e do GPS, pode facilitar a criação de sistema de localização e navegação de veículos. Isto ajudaria os veículos de emergência (equipes de resgate, ambulâncias, polícia e bombeiros) para atender aos chamados. Estes veículos seriam equipados com um receptor GPS e com um computador a bordo, sendo a posição destes seria enviada para uma central que dispõe de um SIG, através de rádio, satélite etc. Esta central ao receber uma chamada de emergência, teria a posição de todos os veículos, podendo, desta forma, mandar o que estivesse mais próximo à ocorrência e fornecer para este o caminho mínimo para atender à emergência. 


\section{ANEXOS}




\section{ANEXO A}

\section{EXEMPLO DO ARQUIVO DE SAÍDA DO PROCESSAMENTO COM O SOFTWARE TRIMVEC}

Project Name:

Processed:

Solution Output File (SSF):

From Staion:

Data File:

Antenna Height (meters):

Position Quality:

WGS 84 Position:

To Station:

Data File:

Antenna Height (meters):

WGS 84 Position:

Star Time:

Stop Time:

Occupation Time Meas. Interval(seconds)

Solution Type:

Solution Acceptability:

Ephemeris:

Baseline Slope Distance Std.Dev.(meters)
Rio Claro

Sunday, 10 de November de 1996 22:18

WAVE 2.000

00000200.SSF

FED1

FED13101.DAT

0.138 True Vertical

Fixed Control

$\begin{array}{lll}\text { 215'54.149660”S } & \text { X } & 3969216.884 \\ \text { 4752'44.295490”W } & \text { Y } & -4389579.534 \\ 848.946 & \text { Z } & -2372852.580\end{array}$

PT01

PT013100.DAT

1.190 True Vertical

$\begin{array}{lll}\text { 22 }^{\circ} 26^{\prime} 14.404715^{\prime} \mathrm{S} & \mathrm{X} & 3979713.042 \\ \text { 47'34'16.494544”W } & \mathrm{Y} & -4353948.847 \\ 597.864 & \mathrm{Z} & -2419472.591\end{array}$

5/11/96 12:34:10.00 GPS $\quad$ (878218050.00) 5/11/96 14:35:10.00 GPS (878225310.00) 02:01:00

10.00

Iono free fixed double difference Passed Ratio Test

Broadcast

59607.698

0.000250

Normal Section Azimuth:

Vertical Angle:

Baseline Components (meters):

Standard Deviations (meters):

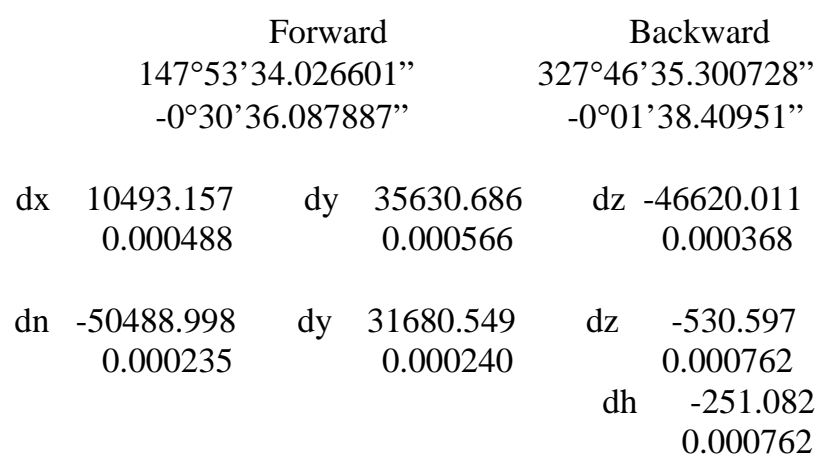


Aposteriori Covariance Matrix:

Variance Ratio Cutoff:

Reference Variance:

Observable Count/ Rejected
2.384873E-007

-2.188104E-007 3.203300E-007

-1.270620E-007 -1.401038E-007 1.354867E-007

1.5

0.797

1.5

RMS: Iono free phase

$3355 / 37$

0.010 


\title{
ANEXO B
}

\section{EXEMPLO DE UM TRECHO DO ARQUIVO DE SAÍDA DO PROCESSAMENTO COM O SOFTWARE SKY}

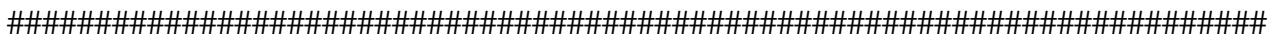 \\ \# GE_PS PROJECT SETTINGS \\ \#

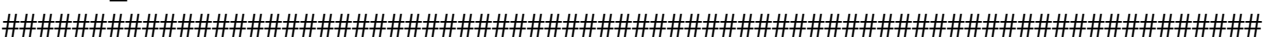

Processing software : Leica SKI / Data processing version 2.1

General header : LEICA AG, CH-9435 Heerbrugg

Project name : pira

Coordinate system : WGS84

Time : All results in local time (GPS + $0.00 \mathrm{hr}$ )

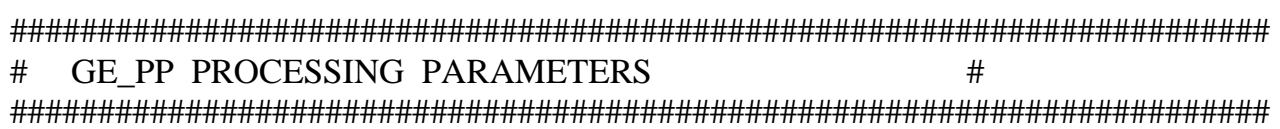

Cut-off angle (deg) : $\quad: 10$

Tropospheric model : Hopfield

Ionospheric model : : Standard

Ephemeris : Broadcast

Data used : Use Code and Phase

Phase Frequency : : Automatic

Code Frequency : Automatic

Limit to resolve ambiguities $(\mathrm{km}) \quad$ : 20

a priori $\mathrm{rms}(\mathrm{mm}) \quad: 20$

Sampling rate for static (sec) : Use all

Phase processing : Automatic

Cycle slip detection : : Phase check \& loss lock flag

Update rate for kinematic (epoch) : : 1

Min. time to fix amb. - L1 only (min) : 9

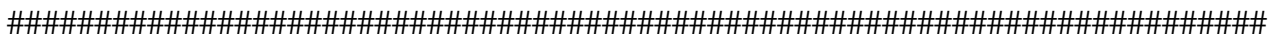
\# GE_SS SATELLITE SELECTION \#

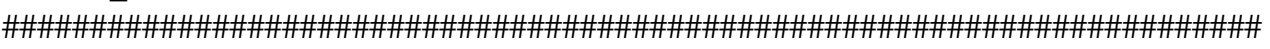

Manually disabled satellites : None

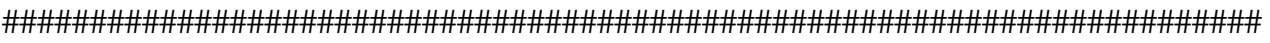
\# GE_BO BASELINE OVERVIEW \#

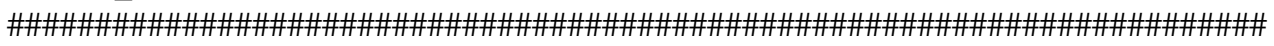

Total no of baselines computed : 14 


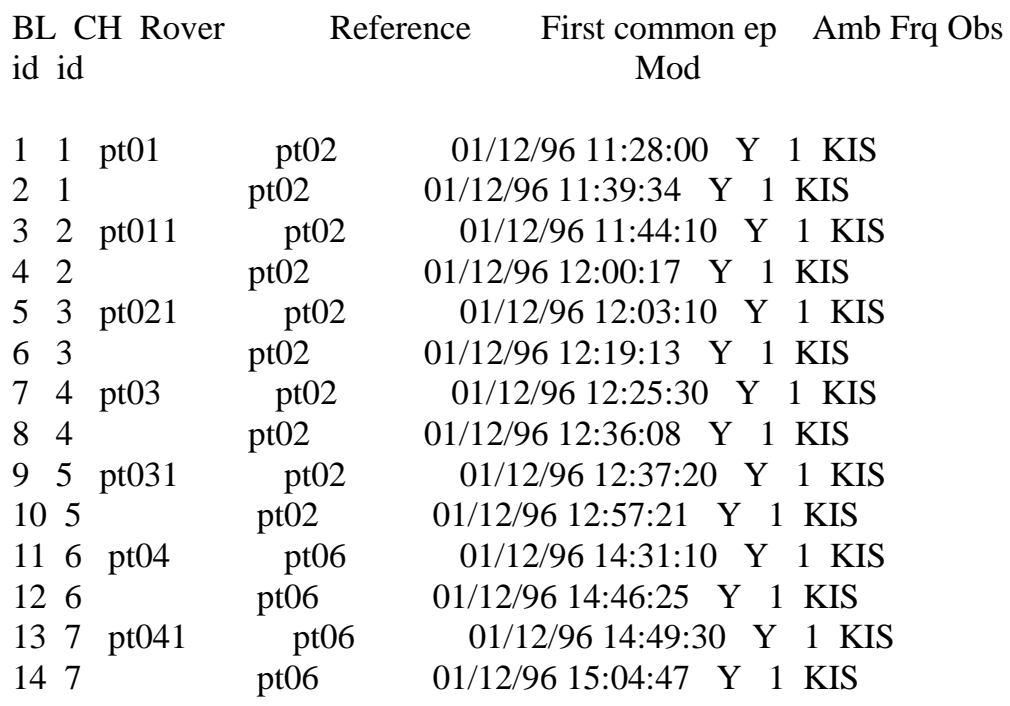

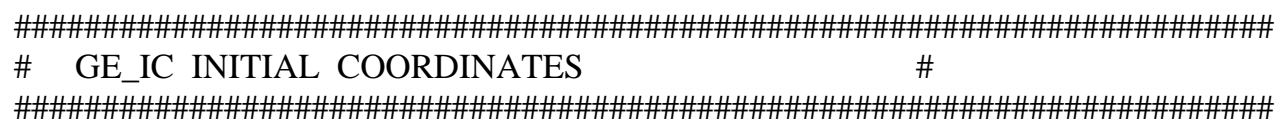

Reference :

Point id : pt02

X $3977899.2536 m \quad Y-4353202.3617 m \quad$ Z -2423600.5892 m

Lat $222840.42751 \mathrm{~S}$ Lon $473445.62927 \mathrm{~W}$ h $536.5660 \mathrm{~m}$

Point id : pt06

X $3971126.9241 \mathrm{~m} \quad \mathrm{Y}-4349831.3203 \mathrm{~m} \quad \mathrm{Z}-2440687.3797 \mathrm{~m}$

Lat $223841.35415 \mathrm{~S}$ Lon $473621.07368 \mathrm{~W}$ h $576.0110 \mathrm{~m}$

Rover :

Point id : pt01

X $3979710.0416 m \quad Y-4353948.8473 m \quad Z-2419472.5912 m$

Lat $222614.40472 \mathrm{~S}$ Lon $473416.49454 \mathrm{~W}$ h $597.8640 \mathrm{~m}$

Point id : pt011

X $3978344.7638 m \quad Y-4353587.3083$ m Z -2422300.5418 m

Lat $222754.11130 \mathrm{~S}$ Lon $473443.20873 \mathrm{~W}$ h $579.9613 \mathrm{~m}$

Point id : pt021

X $3977838.5044 m \quad Y-4353100.2619 m \quad Z-2423920.9094 m$

Lat $222851.49502 \mathrm{~S}$ Lon $473444.78881 \mathrm{~W}$ h $551.5309 \mathrm{~m}$

Point id : pt03

X $3976631.1699 m \quad Y-4352507.5729 m \quad Z-2426870.2127 m$

Lat $223035.64311 \mathrm{~S}$ Lon $47351.98300 \mathrm{~W}$ h $523.2820 \mathrm{~m}$

Point id : pt031

X $3976436.2568 \mathrm{~m} \quad \mathrm{Y}-4352420.1157 \mathrm{~m} \quad \mathrm{Z}-2427415.1645 \mathrm{~m}$

Lat $223054.44767 \mathrm{~S}$ Lon $47354.95368 \mathrm{~W}$ h $550.8378 \mathrm{~m}$

Point id : pt04

X 3975299.0825 m $\quad$ Y -4351072.4787 m Z -2431846.9848 m 
Lat $223329.46015 \mathrm{~S}$ Lon $47352.52368 \mathrm{~W}$ h $622.0430 \mathrm{~m}$

Point id : pt041

X $3974586.0415 \mathrm{~m} \quad \mathrm{Y}-4350859.6978 \mathrm{~m} \quad \mathrm{Z}-2433354.5726 \mathrm{~m}$

Lat $223422.67268 \mathrm{~S}$ Lon $473515.92558 \mathrm{~W}$ h $611.3837 \mathrm{~m}$

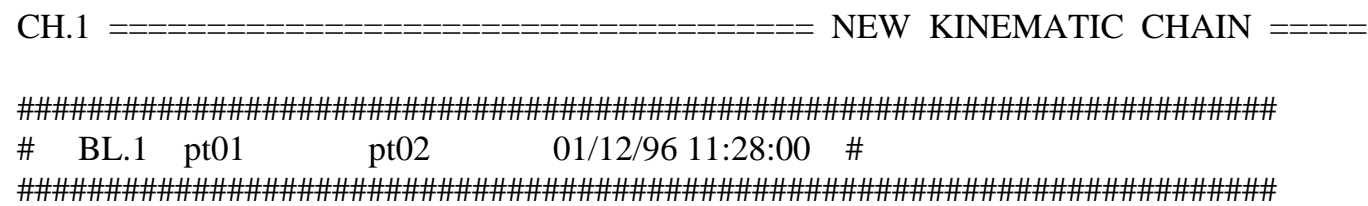

BL_SE.1 START / END (COMMON) EPOCHS

01/12/96 11:28:00 to $01 / 12 / 9611: 38: 44$

BL_OI.1 OPERATION INFORMATION

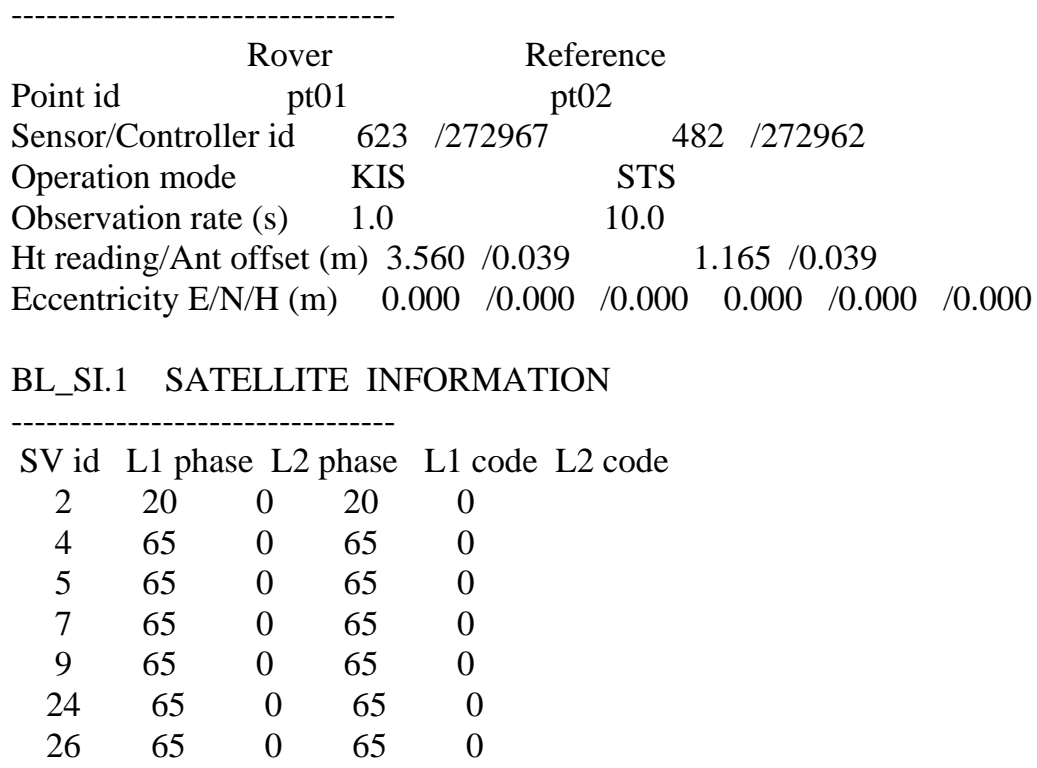

BL_EA.1 ELEVATION / AZIMUTH

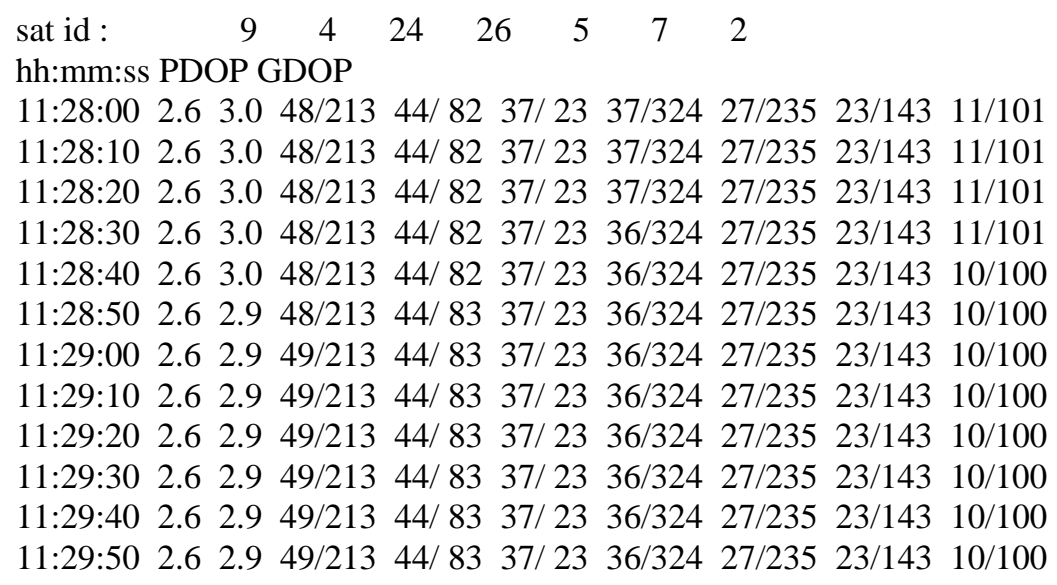


$\begin{array}{llllllllll}11: 30: 00 & 2.6 & 2.9 & 49 / 213 & 44 / 83 & 38 / 24 & 36 / 325 & 27 / 234 & 23 / 143 & 10 / 100\end{array}$ $\begin{array}{lllllllllll}11: 30: 10 & 2.6 & 2.9 & 49 / 213 & 44 / 83 & 38 / 24 & 36 / 325 & 27 / 234 & 22 / 143 & 10 / 100\end{array}$ $\begin{array}{lllllllllll}11: 30: 20 & 2.6 & 2.9 & 49 / 213 & 44 / 84 & 38 / 24 & 36 / 325 & 27 / 234 & 22 / 143 & 10 / 100\end{array}$ $\begin{array}{lllllllllll}11: 30: 30 & 2.6 & 2.9 & 49 / 213 & 44 / 84 & 38 / 24 & 36 / 325 & 27 / 234 & 22 / 143 & 10 / 100\end{array}$ $\begin{array}{lllllllllll}11: 30: 40 & 2.5 & 2.9 & 49 / 213 & 44 / 84 & 38 / 24 & 36 / 325 & 27 / 234 & 22 / 143 & 10 / 100\end{array}$ $\begin{array}{lllllllllll}11: 30: 50 & 2.5 & 2.9 & 49 / 213 & 44 / 84 & 38 / 24 & 36 / 325 & 27 / 234 & 22 / 143 & 10 / 100\end{array}$ $\begin{array}{llllllllllll}11: 31: 00 & 2.5 & 2.9 & 49 / 213 & 44 / 84 & 38 / 24 & 36 / 325 & 27 / 234 & 22 / 143 & 10 / 100\end{array}$

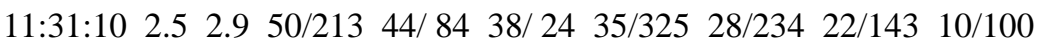
sat id : $\quad 9 \quad 4 \quad 24 \quad 26 \quad 5 \quad 7$

hh:mm:ss PDOP GDOP

11:31:20 $3.5 \quad 4.0 \quad 50 / 213 \quad 44 / 84 \quad 38 / 24 \quad 35 / 325 \quad 28 / 234 \quad 22 / 143$

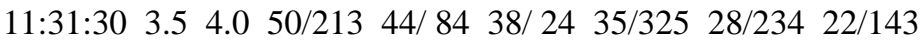
11:31:40 $3.4 \quad 4.0 \quad 50 / 213 \quad 44 / 84 \quad 38 / 24 \quad 35 / 325 \quad 28 / 234 \quad 22 / 143$ $\begin{array}{lllllllll}11: 31: 50 & 3.4 & 4.0 & 50 / 213 & 44 / 85 & 38 / 24 & 35 / 325 & 28 / 234 & 22 / 142\end{array}$ 11:32:00 $3.4 \quad 3.9 \quad 50 / 213 \quad 44 / 85 \quad 38 / 24 \quad 35 / 325 \quad 28 / 234 \quad 22 / 142$ $\begin{array}{lllllllll}11: 32: 10 & 3.4 & 3.9 & 50 / 213 & 44 / 85 & 38 / 24 & 35 / 325 & 28 / 234 & 22 / 142\end{array}$ 11:32:20 $3.4 \quad 3.9 \quad 50 / 213 \quad 44 / 85 \quad 39 / 24 \quad 35 / 325 \quad 28 / 233 \quad 22 / 142$ $\begin{array}{llllllllll}11: 32: 30 & 3.4 & 3.9 & 50 / 213 & 44 / 85 & 39 / 24 & 35 / 326 & 28 / 233 & 22 / 142\end{array}$ $\begin{array}{lllllllll}11: 32: 40 & 3.4 & 3.9 & 50 / 213 & 44 / 85 & 39 / 24 & 35 / 326 & 28 / 233 & 22 / 142\end{array}$ $\begin{array}{lllllllll}11: 32: 50 & 3.4 & 3.9 & 50 / 213 & 44 / 85 & 39 / 24 & 35 / 326 & 28 / 233 & 21 / 142\end{array}$ 11:33:00 $3.3 \quad 3.9 \quad 50 / 213 \quad 44 / 85 \quad 39 / 24 \quad 35 / 326 \quad$ 28/233 $21 / 142$ $\begin{array}{lllllllll}11: 33: 10 & 3.3 & 3.8 & 50 / 213 & 44 / 85 & 39 / 25 & 35 / 326 & 28 / 233 & 21 / 142\end{array}$ $\begin{array}{lllllllll}11: 33: 20 & 3.3 & 3.8 & 50 / 213 & 44 / 86 & 39 / 25 & 35 / 326 & 28 / 233 & 21 / 142\end{array}$ 11:33:30 $3.3 \quad 3.8 \quad 51 / 213 \quad 45 / 86 \quad 39 / 25 \quad 35 / 326 \quad$ 28/233 $21 / 142$

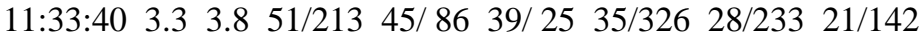
$\begin{array}{lllllllll}11: 33: 50 & 3.3 & 3.8 & 51 / 213 & 45 / 86 & 39 / 25 & 35 / 326 & 28 / 233 & 21 / 142\end{array}$ 11:34:00 $3.3 \quad 3.8 \quad 51 / 213 \quad 45 / 86 \quad 39 / 25 \quad 34 / 326 \quad$ 28/233 $21 / 142$

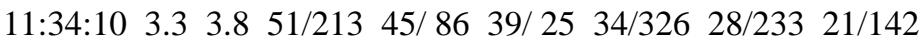

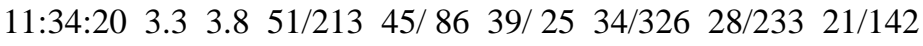

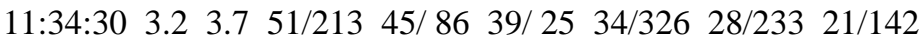
$\begin{array}{lllllllll}11: 34: 40 & 3.2 & 3.7 & 51 / 213 & 45 / 87 & 40 / 25 & 34 / 326 & 28 / 232 & 21 / 142\end{array}$ $\begin{array}{lllllllll}11: 34: 50 & 3.2 & 3.7 & 51 / 213 & 45 / 87 & 40 / 25 & 34 / 326 & 28 / 232 & 21 / 142\end{array}$ 11:35:00 $3.2 \quad 3.7 \quad 51 / 213 \quad 45 / 87 \quad 40 / 25 \quad 34 / 326 \quad$ 28/232 $21 / 142$ $\begin{array}{lllllllll}11: 35: 10 & 3.2 & 3.7 & 51 / 213 & 45 / 87 & 40 / 25 & 34 / 327 & 28 / 232 & 21 / 142\end{array}$ $\begin{array}{lllllllll}11: 35: 20 & 3.2 & 3.7 & 51 / 213 & 45 / 87 & 40 / 25 & 34 / 327 & 28 / 232 & 21 / 142\end{array}$ $\begin{array}{llllllllll}11: 35: 30 & 3.2 & 3.7 & 51 / 213 & 45 / 87 & 40 / 25 & 34 / 327 & 28 / 232 & 20 / 142\end{array}$ $\begin{array}{lllllllll}11: 35: 40 & 3.2 & 3.7 & 52 / 213 & 45 / 87 & 40 / 25 & 34 / 327 & 28 / 232 & 20 / 142\end{array}$ $\begin{array}{lllllllll}11: 35: 50 & 3.2 & 3.6 & 52 / 213 & 45 / 87 & 40 / 25 & 34 / 327 & 28 / 232 & 20 / 142\end{array}$ 11:36:00 $3.2 \quad 3.6 \quad 52 / 213 \quad 45 / 87 \quad 40 / 25 \quad 34 / 327 \quad 28 / 232 \quad$ 20/142 $\begin{array}{lllllllll}11: 36: 10 & 3.1 & 3.6 & 52 / 213 & 45 / 88 & 40 / 25 & 34 / 327 & 29 / 232 & 20 / 142\end{array}$

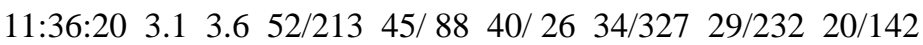
$\begin{array}{lllllllll}11: 36: 30 & 3.1 & 3.6 & 52 / 213 & 45 / 88 & 40 / 26 & 34 / 327 & 29 / 232 & 20 / 142\end{array}$ $\begin{array}{lllllllll}11: 36: 40 & 3.1 & 3.6 & 52 / 213 & 45 / 88 & 40 / 26 & 33 / 327 & 29 / 232 & 20 / 142\end{array}$ $\begin{array}{lllllllll}11: 36: 50 & 3.1 & 3.6 & 52 / 213 & 45 / 88 & 40 / 26 & 33 / 327 & 29 / 232 & 20 / 142\end{array}$ $\begin{array}{lllllllll}11: 37: 00 & 3.1 & 3.6 & 52 / 213 & 45 / 88 & 41 / 26 & 33 / 327 & 29 / 231 & 20 / 142\end{array}$ $\begin{array}{lllllllll}11: 37: 10 & 3.1 & 3.5 & 52 / 213 & 45 / 88 & 41 / 26 & 33 / 327 & 29 / 231 & 20 / 142\end{array}$

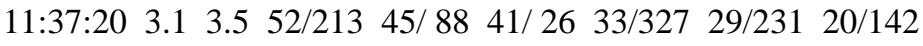

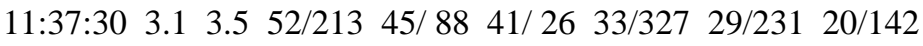

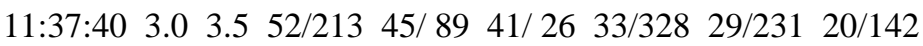

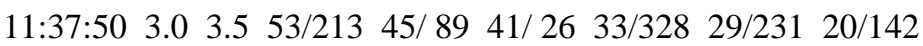
11:38:00 $3.0 \quad 3.5 \quad 53 / 213 \quad 45 / 89 \quad 41 / 26 \quad 33 / 328$ 29/231 $20 / 142$

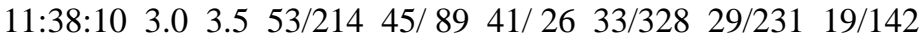

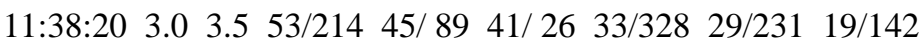
11:38:30 $3.0 \quad 3.5 \quad 53 / 214 \quad 45 / 89 \quad 41 / 26 \quad 33 / 328 \quad 29 / 231 \quad 19 / 142$ 11:38:40 $3.0 \quad 3.4 \quad 53 / 214 \quad 45 / 89 \quad 41 / 26 \quad 33 / 328$ 29/231 19 19/142 


\section{BL_PI.1 PROCESSING INFORMATION}

General Information

Reference receiver type : : SR9400

Reference antenna type : : AT201

Rover receiver type : SR9400

Rover antenna type : : AT201

Total number of used measurements $\quad: \quad 410$

Total number of ambiguities $\quad: \quad 7$

Reference satellite L1 : 9

Root mean square unit weight $\quad$ : 0.1455

\section{BL_FS.1 FARA STATISTICS}

Search Statistic

$\begin{array}{ccc}\text { set\# } & \text { rms } & \text { ratio } \\ 1 & 0.0029 & 1.0000 \\ 2 & 0.0049 & 1.6757\end{array}$

Ambiguity Values

set\# 4/L1 24/L1 26/L1 5/L1 7/L1 2/L1

$\begin{array}{lllllll}1 & -6 & 6 & 6 & -15 & 7 & -10\end{array}$

$\begin{array}{lllllll}2 & 1 & 11 & 6 & -17 & 13 & -1\end{array}$

Statistical Summary

rms a priori $\quad: 20.0[\mathrm{~mm}]$ rms float $\quad 2.5[\mathrm{~mm}]$

Test (rms float $<$ rms a priori) : passed

Error prob. alpha : 5.000 [\%]

rms fix $1 \quad$ : 2.9 [mm]

Test (rms fix $1<$ rms a priori) : passed

Error prob. alpha : 5.000 [\%]

Test (rms fix $1<$ rms fix 2) : passed

Error prob. alpha : 0.001 [\%] 


\section{BL_CS.1 CYCLE SLIP INFORMATION}

Total no of cycle slips : 0

BL_FC.1 FINAL COORDINATES

Rov:pt01 Ref:pt02 Amb:Y Proc: L1 phase 01/12/96 11:28:00

Cartesian :

$\begin{array}{cccccc}\mathrm{X} & 3979710.7475 \mathrm{~m} & \mathrm{Y} & -4353948.1451 \mathrm{~m} & \mathrm{Z} & -2419472.3431 \mathrm{~m} \\ \mathrm{dX} & 1811.4939 \mathrm{~m} & \mathrm{dY} & -745.7834 \mathrm{~m} & \mathrm{dZ} & 4128.2461 \mathrm{~m} \\ \mathrm{sX} & 0.0013 \mathrm{~m} & \mathrm{sY} & 0.0015 \mathrm{~m} & \mathrm{sZ} & 0.0009 \mathrm{~m}\end{array}$

Geodetic :

Lat $222614.39779 \mathrm{~S}$ Lon $473416.45975 \mathrm{~W}$ h $597.7304 \mathrm{~m}$

dLat 226.02972 dLon 29.16952 dh $61.1644 \mathrm{~m}$

sLat $\quad 0.0005 \mathrm{~m}$ sLon $0.0005 \mathrm{~m}$ sh $0.0020 \mathrm{~m}$

Distance :

Slope $\quad 4569.4769 \mathrm{~m}$ sSlope $0.0004 \mathrm{~m}$

BL_VC.1 VARIANCE-COVARIANCE MATRIX

a posteriori rms : 0.1455

Co-factor matrix (upper triangle $\left[\mathrm{m}^{*} \mathrm{~m}\right]$ ) :

qx

qy

$\mathrm{qz}$

qx +7.9729063E-005 -7.8381992E-005 -4.2855601E-005

qy +1.0026274E-004 +4.4909222E-005

qz $+3.4157219 \mathrm{E}-005$ 


\section{UM TRECHO DA LISTA DOS PONTOS EM COORDENADAS GEODÉSICAS}

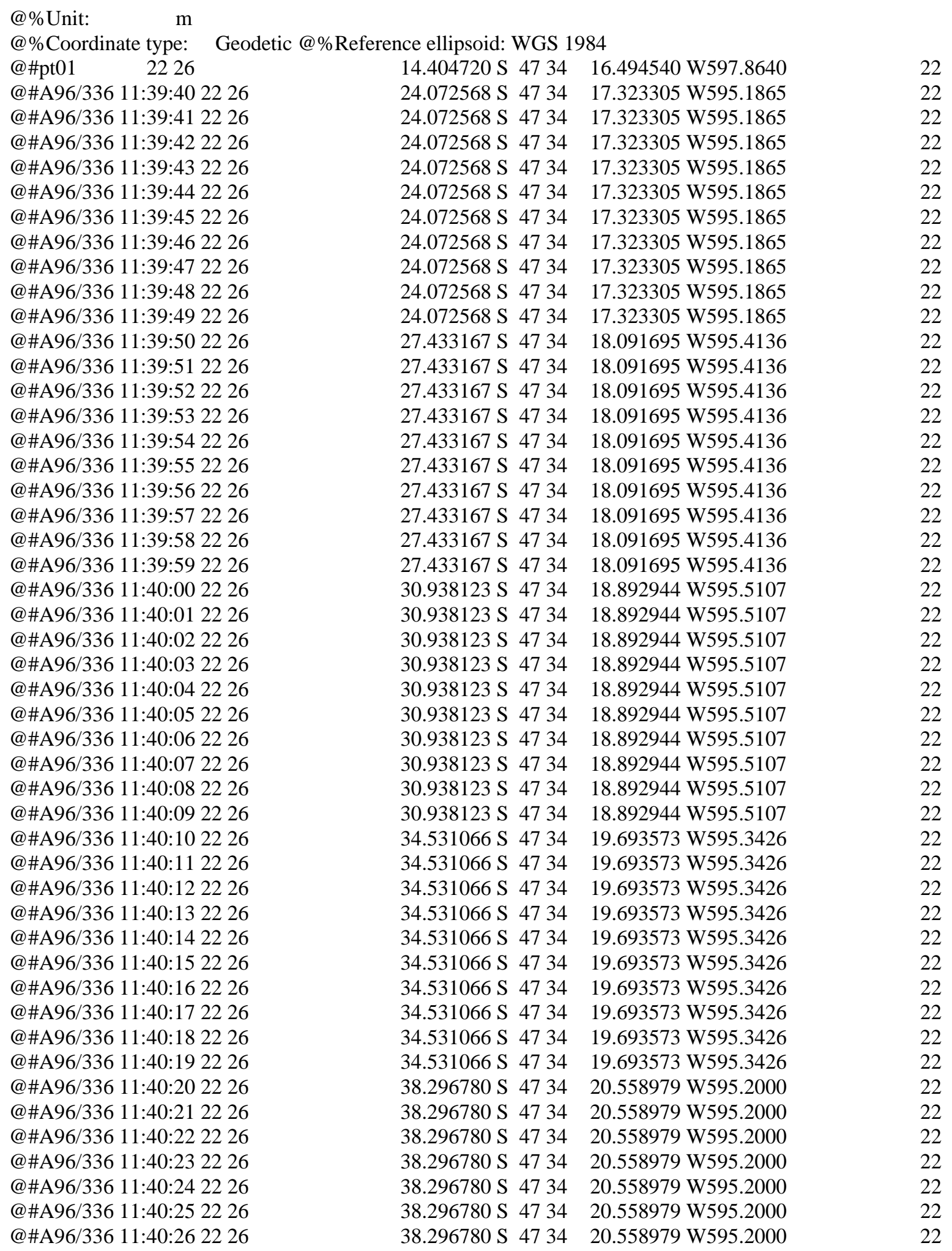


@\#A96/336 11:40:27 2226 @\#A96/336 11:40:28 2226 @\#A96/336 11:40:29 2226 @\#A96/336 11:40:30 2226 @\#A96/336 11:40:31 2226 @\#A96/336 11:40:32 2226 @\#A96/336 11:40:33 2226 @\#A96/336 11:40:34 2226 @\#A96/336 11:40:35 2226 @\#A96/336 11:40:36 2226 @\#A96/336 11:40:37 2226 @\#A96/336 11:40:38 2226 @\#A96/336 11:40:39 2226 @\#A96/336 11:40:40 2226 @\#A96/336 11:40:41 2226 @\#A96/336 11:40:42 2226 @\#A96/336 11:40:43 2226 @\#A96/336 11:40:44 2226 @\#A96/336 11:40:45 2226 @\#A96/336 11:40:46 2226 @\#A96/336 11:40:47 2226 @\#A96/336 11:40:48 2226 @\#A96/336 11:40:49 2226 @\#A96/336 11:40:50 2226 @\#A96/336 11:40:51 2226 @\#A96/336 11:40:52 2226 @\#A96/336 11:40:53 2226 @\#A96/336 11:40:54 2226 @\#A96/336 11:40:55 2226 @\#A96/336 11:40:56 2226 @\#A96/336 11:40:57 2226 @\#A96/336 11:40:58 2226 @\#A96/336 11:40:59 2226 @\#A96/336 11:41:00 2226 @\#A96/336 11:41:01 2226 @\#A96/336 11:41:02 2226 @\#A96/336 11:41:03 2226 @\#A96/336 11:41:04 2226 @\#A96/336 11:41:05 2226 @\#A96/336 11:41:06 2226 @\#A96/336 11:41:07 2226 @\#A96/336 11:41:08 2226 @\#A96/336 11:41:09 2226 @\#A96/336 11:41:10 2226 @\#A96/336 11:41:11 2226 @\#A96/336 11:41:12 2226 @\#A96/336 11:41:13 2226 @\#A96/336 11:41:14 2226 @\#A96/336 11:41:15 2226 @\#A96/336 11:41:16 2226 @\#A96/336 11:41:17 2226 @\#A96/336 11:41:18 2226 @\#A96/336 11:41:19 2226 @\#A96/336 11:41:20 2227
38.296780 S 4734 $38.296780 \mathrm{~S} 4734$ $38.296780 \mathrm{~S} 4734$ $42.000840 \mathrm{~S} 4734$ $42.000840 \mathrm{~S} 4734$ $42.000840 \mathrm{~S} 4734$ $42.000840 \mathrm{~S} 4734$ $42.000840 \mathrm{~S} 4734$ $42.000840 \mathrm{~S} 4734$ $42.000840 \mathrm{~S} 4734$ $42.000840 \mathrm{~S} 4734$ $42.000840 \mathrm{~S} 4734$ 42.000840 S 4734 45.941498 S 4734 45.941498 S 4734 45.941498 S 4734 45.941498 S 4734 45.941498 S 4734 45.941498 S 4734 45.941498 S 4734 45.941498 S 4734 45.941498 S 4734 45.941498 S 4734 $49.898620 \mathrm{~S} 4734$ $49.898620 \mathrm{~S} 4734$ 49.898620 S 4734 49.898620 S 4734 $49.898620 \mathrm{~S} 4734$ $49.898620 \mathrm{~S} 4734$ $49.898620 \mathrm{~S} 4734$ $49.898620 \mathrm{~S} 4734$ $49.898620 \mathrm{~S} 4734$ $49.898620 \mathrm{~S} 4734$ 53.820510 S 4734 53.820510 S 4734 53.820510 S 4734 $53.820510 \mathrm{~S} 4734$ $53.820510 \mathrm{~S} 4734$ $53.820510 \mathrm{~S} 4734$ $53.820510 \mathrm{~S} 4734$ $53.820510 \mathrm{~S} 4734$ 53.820510 S 4734 53.820510 S 4734 57.875009 S 4734 57.875009 S 4734 57.875009 S 4734 57.875009 S 4734 57.875009 S 4734 57.875009 S 4734 57.875009 S 4734 57.875009 S 4734 57.875009 S 4734 $57.875009 \mathrm{~S} 4734$

$1.764991 \mathrm{~S} 4734$
20.558979 W595.2000

20.558979 W595.2000

20.558979 W595.2000

21.408761 W597.2466

21.408761 W597.2466

21.408761 W597.2466

21.408761 W597.2466

21.408761 W597.2466

21.408761 W597.2466

21.408761 W597.2466

21.408761 W597.2466

21.408761 W597.2466

21.408761 W597.2466

22.297212 W598.2732

22.297212 W598.2732

22.297212 W598.2732

22.297212 W598.2732

22.297212 W598.2732

22.297212 W598.2732

22.297212 W598.2732

22.297212 W598.2732

22.297212 W598.2732

22.297212 W598.2732

23.204787 W597.7447

23.204787 W597.7447

23.204787 W597.7447

23.204787 W597.7447

23.204787 W597.7447

23.204787 W597.7447

23.204787 W597.7447

23.204787 W597.7447

23.204787 W597.7447

23.204787 W597.7447

24.101320 W595.6292

24.101320 W595.6292

24.101320 W595.6292

24.101320 W595.6292

24.101320 W595.6292

24.101320 W595.6292

24.101320 W595.6292

24.101320 W595.6292

24.101320 W595.6292

24.101320 W595.6292

25.015311 W593.5345

25.015311 W593.5345

25.015311 W593.5345

25.015311 W593.5345

25.015311 W593.5345

25.015311 W593.5345

25.015311 W593.5345

25.015311 W593.5345

25.015311 W593.5345

25.015311 W593.5345

25.910010 W593.6636
22

22

22

22

22

22

22

22

22

22

22

22

22

22

22

22

22

22

22

22

22

22

22

22

22

22

22

22

22

22

22

22

22

22

22

22

22

22

22

22

22

22

22

22

22

22

22

22

22

22

22

22

22 22

UM TRECHO DA LISTA DOS PONTOS EM COORDENADAS CARTESIANAS 


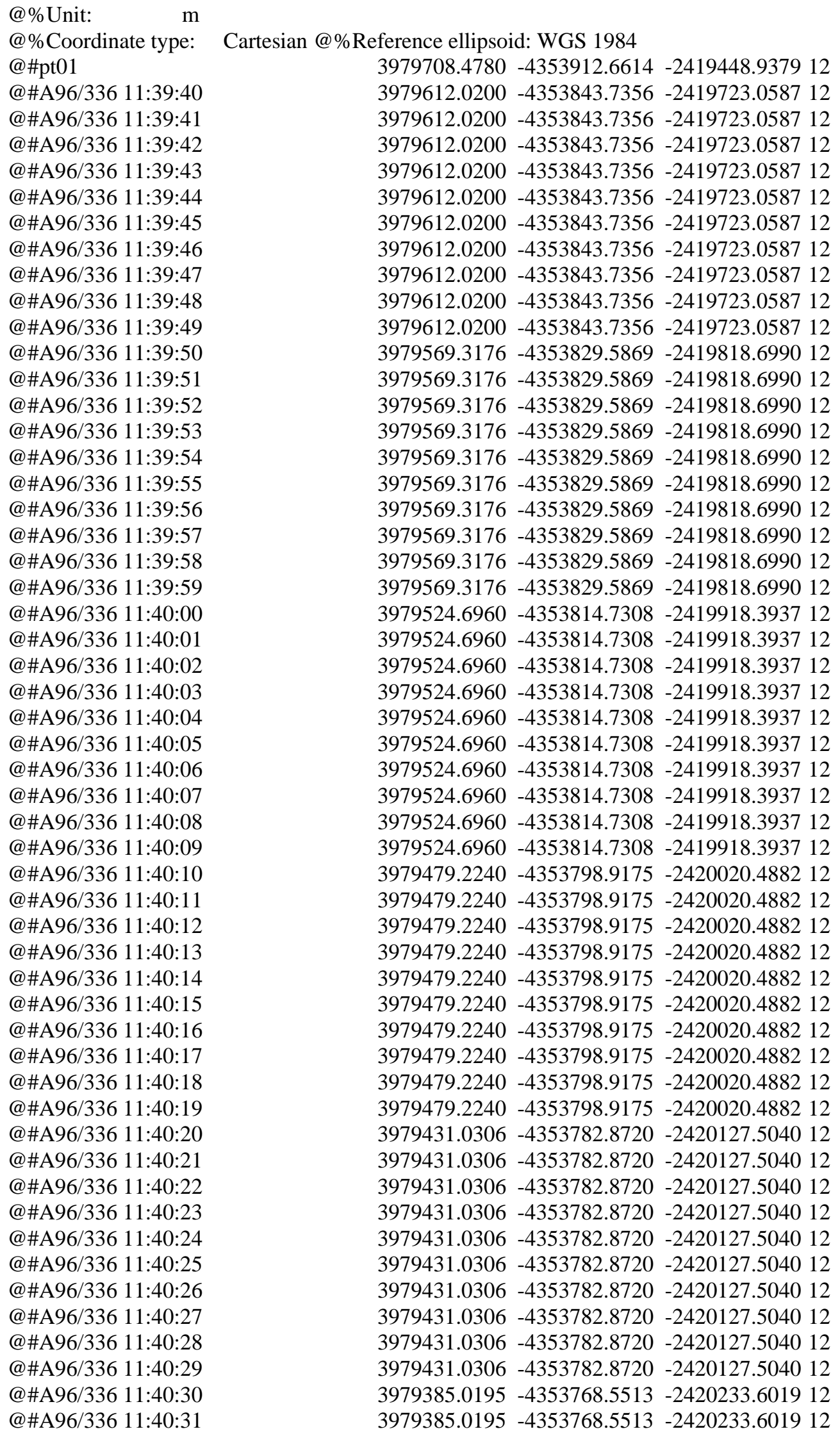


@\#A96/336 11:40:32 @\#A96/336 11:40:33 @\#A96/336 11:40:34 @\#A96/336 11:40:35 @\#A96/336 11:40:36 @\#A96/336 11:40:37 @\#A96/336 11:40:38 @\#A96/336 11:40:39 @\#A96/336 11:40:40 @\#A96/336 11:40:41 @\#A96/336 11:40:42 @\#A96/336 11:40:43 @\#A96/336 11:40:44 @\#A96/336 11:40:45 @\#A96/336 11:40:46 @\#A96/336 11:40:47 @\#A96/336 11:40:48 @\#A96/336 11:40:49 @\#A96/336 11:40:50 @\#A96/336 11:40:51 @\#A96/336 11:40:52 @\#A96/336 11:40:53 @\#A96/336 11:40:54 @\#A96/336 11:40:55 @\#A96/336 11:40:56 @\#A96/336 11:40:57
$3979385.0195-4353768.5513-2420233.601912$ $3979385.0195-4353768.5513-2420233.601912$ $3979385.0195-4353768.5513-2420233.601912$ $3979385.0195-4353768.5513-2420233.601912$ $3979385.0195-4353768.5513-2420233.601912$ $3979385.0195-4353768.5513-2420233.601912$ $3979385.0195-4353768.5513-2420233.601912$ $3979385.0195-4353768.5513-2420233.601912$ $3979335.6807-4353752.2287-2420346.036912$ $3979335.6807-4353752.2287-2420346.036912$ $3979335.6807-4353752.2287-2420346.036912$ $3979335.6807-4353752.2287-2420346.036912$ $3979335.6807-4353752.2287-2420346.036912$ $3979335.6807-4353752.2287-2420346.036912$ $3979335.6807-4353752.2287-2420346.036912$ $3979335.6807-4353752.2287-2420346.036912$ $3979335.6807-4353752.2287-2420346.036912$ $3979335.6807-4353752.2287-2420346.036912$ $3979284.8356-4353735.0676-2420458.345012$ $3979284.8356-4353735.0676-2420458.345012$ $3979284.8356-4353735.0676-2420458.345012$ $3979284.8356-4353735.0676-2420458.345012$ $3979284.8356-4353735.0676-2420458.345012$ $3979284.8356-4353735.0676-2420458.345012$ $3979284.8356-4353735.0676-2420458.345012$ $3979284.8356-4353735.0676-2420458.345012$ 


\section{BIBLIOGRAFIA REFERENCIADA}

BERG, W. D.; CHOI, J.; KUIPERS, E. J. (1989) "Development of Highway Alignment Information from Photolog Data” Transportation Research Record 1239, TRB, pp.54-61.

CALIPER (1995) TRANSCAD - Transportation GIS Software (User Guide)

CALIPER (1997) http.://www.caliper.com

CHOUEIRI, Elias M.; LAMM, Ruediger; KLOECKNER, Juergen H.; MAILAENDER, Theodor (1994) "Safety Aspects of Individual Design Elements and Their Interactions on Two-Lane Highways: International Perspective” Transportation Research Record 1445, TRB, pp.34-46.

CRIOLLO, Alfonso Rodrigo Tierra (1993) "Métodos de Posicionamento Cinemático Relativo-GPS” XVI Congresso Brasileiro de Cartografia, vol. I, pp. 200-207, outubro.

DANGERMOND, Jack (1992) "What is a Geographic Information System (GIS)?" Geographic Information systems (GIS) and Mapping - Practices and Standards" ASTM STP 1126, pp. 11-17

DNER (1995) informativo DEST Divisão de Engenharia e Segurança de Trânsito, fevereiro 
GERDAN, George P. (1992) "Efficient Surveying with the Global Positioning System” Surveying and Land Information Systems, vol. 52, no.1, pp.34-40.

GEOTRONICS (1997) http.://www.geotronics.com

GLENNON, John C. (1987). "Effect of Alignment on Highway Safety” State of the Art Report 6 - Relationships between Safety and Key Highways Features, TRB, pp. 48-63.

GOLDSTINE, Rachel (1991). “Influence of Road Width on Accident Rates by Traffic Volume” Transportation Research Record 1318, TRB, pp. 64-69.

HOFFMANN-WELLENHOF, B.; LICHTENEGGER, H.; Collins, J. (1994). GPS Theory and Practice, terceira edição, Austria, editora Springer -Verlag Wien.

KAHMEN, Heribert \& FAIG, Wolfgang (1988) Surveying, New York, editora Walter de Gruyter.

LEICK, A. (1996) http://www.spatial.maine.edu/ leick/gps_orb.htm

LAMM, Ruediger; CHOUEIRI, Elias M.; HAYWARD, John C.; PALURI, Anand (1988) "Possible Design Procedure to Promote Design Consistency in Highway Geometric Design on Two-Lane Rural Roads” Transportation Research Record 1195, TRB, pp.111-122.

LAUNEN, Kari J. (1993) “GGS-Rapid Solutions for Transportation Management” Journal of Surveying Engineering, vol.119, no.1, p. 40-49, February.

LI, Jian; ABDELWAHAB, Walid; BROWN, Gerald (1994) “Join Effects of Access and Geometry on Two-Lane Rural Highway Safety in British Columbia” Canadian Journal of Civil Engineering, vol. 21, no. 6, pp.1012-1024, December. 
LOGAN, Kevin P. (1988) “A Comparison: Static and Future Kinematic GPS Surveys” Journal of Surveying Engineering, vol.114, no.4, p.195-201, November.

MIAOU, Shaw-Pin; LUM, Harry (1993) "Statistical Evaluation of the Effects of Highways Geometric Design on Truck Accident Involvements” Transportation Research Record 1407, pp.11-23.

MOAMEDSHAH, Yusuf M.; PANIATI, Jeffery F.; HOBEIKA, Antoine G. (1993) “Truck Accident Models for Interstates and Two-Lane Rural Roads" Transportation Research Record 1407, TRB, pp.35-41.

NEWCOMER, David (1990) “GPS as Fast Surveying Tool” Journal of Surveying Engineering, vol.116, no. 2, pp. 75-81, May.

NOGUEIRA, A. A. R. (1994) Análise da Relação Geometria de Rodovias e Acidentes Envolvendo Veículos de Carga, São Carlos. Dissertação de Mestrado Escola de Engenharia de São Carlos, Universidade de São Paulo.

NARD, George Pierre; WEEMS, Lynn (1989) "GPS Geodesy and Kinematic Topography Measurements and Results” Journal of Surveying Engineering, vol.115, no.2, pp. 166-180, May.

NOVAK, Kurt (1995) “Mobile Mapping Technology for GIS Data Collection” Photogrammetric Engineering \& Remote Sensing, vol. 61, no. 5, pp.493-501, May.

PIMENTA, Carlos R. T (1991) Projeto de Estradas, vol. 2 e vol. 3, São Carlos, publicação da Escola de Engenharia de São Carlos. 
PLING, Allen; LEE, Jim; GEFERSON, Patrick; HANDLY, Paul “Comparison of Two Sign Inventory Data Collection Techniques for Geographic Information Systems” Transportation Research Record 1429, pp.36-39

RABBANI, Simim J. R.; RABBANI, Soheil R.; MEDEIROS, Rosinaldo do Rio (1994) “Acidentes de Tráfego e Características Geométricas das Vias” VII Congresso de Pesquisa e Ensino em Transportes, vol. I, pp. 405-414, Recife.

REINFURT, Donald W., ZEGEER, Charles; SHELTON, Brent J.; NEUMAN, Timothy R. (1991) “Analysis of Vehicle Operations on Horizontal Curves" Transportation Research Record 1318, TRB, pp.43-50.

SANTOS, Benjamim J. R. (1992) Consistência da Geometria de Rodovias. São Carlos, 60 p. Dissertação (Mestrado) - Escola de Engenharia de São Carlos, Universidade de São Paulo.

SCHOFIELD, W. (1993) Engineering Surveying, quarta edição, Inglaterra, editora Butterworth-Heinemann Ltd .

SEEBER, Günter (1993) Satellite Geodesy Foundation Methods, and Application , New York, Editora Walter de Gruyter.

SEGANTINE, Paulo C. Lima (1988) Aerofotointerpretação e Fotogrametria Notas de Aula, publicação da Escola de Engenharia de São Carlos.

SEGANTINE, Paulo C. Lima (1995) “GPS: História, Características e Situação Atual” IX Congresso de Pesquisa e Ensino em Transportes, vol.1, pp.47-58, novembro, São Carlos.

SEGANTINE, Paulo C. Lima (1996) “Curso de Atualização em Topografia e GPS”, junho. 
SHRESTHA, Ramesh; CAMPBELL, Mike; PIAZZA, Alex (1994) “A Global Positioning System Base Station and Session Length for 1-m Accuracy” Surveying and Land Information Systems, vol.54, no.1, pp. 51-57.

SIMKOWITZ, Howard J. (1989) “Geographic Information Systems: An Important Technology of Transportation Planning and Operations" Transportation Research Record 1236, pp. 14-22

SMITH, Bob L.; LAMM, Ruediger (1994) "Coordination of Horizontal and Vertical Alignment with Regard to Highway Esthetics” Transportation Research Record 1445, pp. 73-85, TRB.

ST JOHN, Andrew D.; HARWOOD, Douglas W. (1991) “Safety Considerations for Truck Climbing Lanes on Rural Highways” Transportation Research Record 1303, TRB, pp. 74-82.

STOKES, Robert W.; MARUCCI, Giancarlo (1995) “GIS for Transportation: Current Practices, Problems and Prospects” ITE Journal, March, pp.28-32

TALARICO, R. J.; MORRALL, J. F. (1994) “The cost-effectiveness of curve flattening in Alberta” Canadian Journal of Civil Engineering, vol. 21, no. 2, pp.285-296, April.

U. S. NATIONAL ACADEMY OF SCIENCE TRB (1987) Designing Safer Roads Practices for Resurfacing, Restoration, and Rehabilitation, Special Report 214, Washington, D.C, pp.77-109, TRB.

URBANIK II, Thomas; HINSHAW, Wanda; FAMBRO, Daniel B. (1989) “Safety Effects of Limits Sight Distance on Crest Vertical Curves" Transportation Research Record 1208, TRB, pp. 23-35. 
WOOD, Leonard P. (1989) “Combined Photogeodesy and GPS Network” Journal of Surveying Engineering, vol.115, no.1, pp.160-163, February.

ZEEGER, Charles V.; DEACON, John A. (1987) "Effect of Lane Width, Shoulder Width, and Shoulder Type on the Highway Safety" State of the Art Report 6 Relationships between Safety and Key Highways Features, TRB, pp.1-21.

ZEGEER, Charles V.; STEWART, J. Richard; COUNCIL, Forrest M.; REINFURT, Donald W.; HAMILTON, Elizabeth (1992) "Safety Effects of Geometric Improvements on Horizontal Curves” Transportation Research Record 1356, TRB, pp. 11-19 


\section{BIBLIOGRAFIA REFERENCIADA INDIRETAMENTE}

ALBERTA TRANSPORTATION AND UTILITIES (1992) Minimum Geometric Standards for 3R Projects in Alberta. 4th draft. Edmonton, Alta apud TALARICO, R. J.; MORRALL, J. F. (1994) “The cost-effectiveness of curve flattening in Alberta” Canadian Journal of Civil Engineering, vol. 21, no. 2, pp.285-296, April.

ALLISON, T.; ESCHENBACH, R. (1989) “Real Time Cycle-Slip Filing During Kinematic Surveys” Proc. 5th Int.Geod. Symp. Satellite Positioning, vol. I, pp. 330-337, Las Cruzes apud SEEBER, Günter (1993) Satellite Geodesy Foundation Methods, and Application, New York, Editora Walter de Gruyter.

BOX, P. C. \& ASSOCIATES (1970) "Traffic Control and Roadway Elements Their Relationship to Highway Safety” Chapter 4. Intersections; Chapter 5. Driveways. Highway Users Federation for Safety and Mobility apud LI, Jian; ABDELWAHAB, Walid; BROWN, Gerald (1994) “Join Effects of Access and Geometry on Two-Lane Rural Highway Safety in British Columbia” Canadian Journal of Civil Engineering, vol. 21, no. 6, pp.1012-1024, December.

BRINKMAN, C. P. \& SMITH, S. A. (1984) "Two-Lane Rural Highway Safety” Public Roads, vol. 48, No. 2, Sept., pp.48-53 apud U. S. NATIONAL ACADEMY OF SCIENCE TRB (1987) Designing Safer Roads Practices for Resurfacing, Restoration, and Rehabilitation, Special Report 214, Washington, D.C, pp.77-109, TRB. 
CHOUEIRI, E. M. (1987) "Statistical Analysis of Operating Speeds and Accident Rates on Two-Lane Rural Highways. Ph. D. Dissertation . Department of Civil Engineering, Clarkson University, Potsdam, N.Y. apud CHOUEIRI, Elias M.; LAMM, Ruediger; KLOECKNER, Juergen H.; MAILAENDER, Theodor (1994) “Safety Aspects of Individual Design Elements and Their Interactions on Two-Lane Highways: International Perspective” Transportation Research Record 1445, TRB, p.34-46.

CHOUEIRI, E. M.; LAMM, R.; MAILAENDER, T. (1991) “Statistical Evaluation Procedure for Comparing Fatality Trends with Special Emphais on High Risk Target Groups - USA vs Western Europe, 1970-1987” The Second International Conference on New Ways for Improved Road Safety and Quality of Life”, Tel Aviv, Oct, pp. 132-138 apud CHOUEIRI, Elias M.; LAMM, Ruediger; KLOECKNER, Juergen H.; MAILAENDER, Theodor (1994) "Safety Aspects of Individual Design Elements and Their Interactions on Two-Lane Highways: International Perspective” Transportation Research Record 1445, TRB, p.34-46

DART, O. K. \& MANN Jr., L., (1970) "Relationship of Rural Highway Geometry to Accident Rates in Louisiana” Highway Research Record 312, HRB, pp. 1-16 apud LI, Jian; ABDELWAHAB, Walid; BROWN, Gerald (1994) “Join Effects of Access and Geometry on Two-Lane Rural Highway Safety in British Columbia” Canadian Journal of Civil Engineering, vol. 21, no. 6, pp.1012-1024, December.

DILDINE, G. (1988) Geographic Information Systems Task Force Feasibility Report, North Carolina Department of Transportation, Division Highway, Raleigh, N. C., May apud SIMKOWITZ, Howard J. (1989) “Geographic Information Systems: An Important Technology of Transportation Planning and Operations” Transportation Research Record 1236, p. 14-22 
EVANS, A. G. (1986) “Comparison of GPS Pseudorange and Biased Doppler Range Measurements to Demonstrate Signal Multipath Effects” In: PROCEEDINGS OF THE FOURTH INTERNATIONAL GEODETIC SYMPOSIUM ON SATELLITE POSITIONING, Austin, Texas, April 28- May, vol 1. pp.573-587 apud HOFFMANN-WELLENHOF, B.; LICHTENEGGER, H.; Collins, J. (1994). GPS - Theory and Practice, terceira edição, Austria, editora Springer Verlag Wien.

GLENNON, J. C.; NEUMAN, T. R.; LEISCH, J. E. (1983) “Safety and Operational Considerations for Design of Rural Highway Curves” FHWA, U. S. Department of Transportation, August apud GLENNON, John C. (1987). "Effect of Alignment on Highway Safety” State of the Art Report 6 - Relationships between Safety and Key Highways Features, TRB, pp. 48-63.

GLENNON, J. C.; NEWMAN, T. R.; LEISH, J. E. (1985) "Safety and Operational considerations for Design of Rural Highway Curves” FHWA/RD-86/035, Federal Highway Administration apud TALARICO, R. J.; MORRALL, J. F. (1994) “The cost-effectiveness of curve flattening in Alberta” Canadian Journal of Civil Engineering, vol. 21, no. 2, pp.285-296, April.

GWYNN, D. W. (1966) “Accident Rates and Control of Access” Traffic Engineering, Institute of Traffic Engineers, 37(2), 18-21 apud LI, Jian; ABDELWAHAB, Walid; BROWN, Gerald (1994) “Join Effects of Access and Geometry on Two-Lane Rural Highway Safety in British Columbia” Canadian Journal of Civil Engineering, vol. 21, no. 6, pp.1012-1024, December. 
HIERSCHE, E. U.; LAMM, R.; DIETERLE, K.; NIKPOUR, A. (1984) "Effects of Highway Improvements Designed in Conformity with the RAL-L on Traffic Safety of Two-Lane Rural Highways” Techical Journal: Forschung Strassenbau und Strassenverkehrstechnik, vol. 431 apud CHOUEIRI, Elias M.; LAMM, Ruediger; KLOECKNER, Juergen H.; MAILAENDER, Theodor (1994) “Safety Aspects of Individual Design Elements and Their Interactions on Two-Lane Highways: International Perspective” Transportation Research Record 1445, TRB, p.34-46

HILLA, S. (1986) "Processing Cycle Slips in Nondiffereneed Phase Data from the Macrometer V-1000 Receiver” Proc. 4th Int. Geod. symp. Sat. Positioning, vol. I, pp.647-661, Austin apud SEEBER, Günter (1993) Satellite Geodesy Foundation Methods, and Application, New York, Editora Walter de Gruyter.

JOHNSON, P.; GOAD, K.; ORVETS, G. (1992) “GPS/Imaging/GIS Project: The Aplication of the Global Position System for Transportation Planning, final report, Ohio State University apud NOVAK, Kurt (1995) “Mobile Mapping Technology for GIS Data Collection” Photogrammetric Engineering \& Remote Sensing, vol. 61, no. 5, pp.493-501, May.

KLOBUCHAR, J. A. (1991) “Ionospheric Effects on GPS” GPS World 2 (4), pp.4851 apud SEEBER, G nter (1993) Satellite Geodesy Foundation Methods, and Application, New York, Editora Walter de Gruyter.

KREBS, H. G. \& KLOECKNER, J. H. (1977) "Investigation of the Effects of Highway and Traffic conditions Outside Built-Up areas on Accident Rates” Techical Journal: Forschung Strassenbau und Strassenverkehrstechnik, vol. 223 apud CHOUEIRI, Elias M.; LAMM, Ruediger; KLOECKNER, Juergen H.; MAILAENDER, Theodor (1994) “Safety Aspects of Individual Design Elements and Their Interactions on Two-Lane Highways: International Perspective” Transportation Research Record 1445, TRB, p.34-46 
LAMM, R. \& CHOUEIRI, E. M. (1991) “Traffic Safety on Two Continents - A Ten Year Analysis of Highway and Vehicular Involvements” Strategic Highway Research Program (SHRP) and Traffic Safety on Two Continents, Gothenburg, Sweden, VTIrapport 372A, Part 1. Swedish Road and Traffic Research Institute, Linkoeping, Sweden, pp. 121-136 apud CHOUEIRI, Elias M.; LAMM, Ruediger; KLOECKNER, Juergen H.; MAILAENDER, Theodor (1994) “Safety Aspects of Individual Design Elements and Their Interactions on Two-Lane Highways: International Perspective” Transportation Research Record 1445, TRB, pp.34-46.

LAMM, R. (1982) "Is There an Influence on the Accident Situation by the Superimposition of Horizontal and Vertical curvature in the Alignment?” International Technical Journal: Strassen-und Tiefbau (Road and Construction), vol. 1, jan., p. 16-19; vol. 2, feb., pp. 21-25; vol. 3, march, pp. 20-23 apud SMITH, Bob L.; LAMM, Ruediger (1994) "Coordination of Horizontal and Vertical Alinement with Regard to Highway Esthetics” Transportation Research Record 1445, pp. 73-85, TRB.

LAMM, R. (1984) "Driving Dynamic Considerations: a Comparison of German and American Friction Coefficients for Highway Design” Transportation Research Record 960, TRB, pp.13-20 apud TALARICO, R. J.; MORRALL, J. F. (1994) “The cost-effectiveness of curve flattening in Alberta” Canadian Journal of Civil Engineering, vol. 21, no. 2, pp.285-296, April.

LAMM, R.; CHOUEIRI, E. M. (1987) “Rural Roads Speed Inconsistencies Design Methods" Final Report to the State University of New York Research Foundation, Albany, Part I, Part II, contract RF320-PN 72350 apud CHOUEIRI, Elias M.; LAMM, Ruediger; KLOECKNER, Juergen H.; MAILAENDER, Theodor (1994) "Safety Aspects of Individual Design Elements and Their Interactions on Two-Lane Highways: International Perspective” Transportation Research Record 1445, TRB, p.34-46. 
LANDAU, H. (1988) “Zur Nutzung des Global Positioning Systems in Geodäsie und Geodynamik” Schriftenreihe Studiengang Vermessungswesen, UBW München, H.36, München apud SEEBER, Günter (1993) Satellite Geodesy Foundation Methods, and Application, New York, Editora Walter de Gruyter.

LIN, F. B. (1990) “Flattening Curves on rural Two-lane Highways” Journal of Transportation Engineering, 16 (2): 181-196 apud TALARICO, R. J.; MORRALL, J. F. (1994) "The cost-effectiveness of curve flattening in Alberta” Canadian Journal of Civil Engineering, vol. 21, no. 2, pp.285-296, April.

LOOMIS, F. J.; GEIER, G. J. Inertially Aided Lane Recapture After GPS Carrier Lock Loss. IN: Schwarz, Lachapelle (eds), pp 309-318 apud SEEBER, Günter (1993) Satellite Geodesy Foundation Methods, and Application , New York, Editora Walter de Gruyter.

McCARTHY, J.; SCRUGGS, J. C.; BROWN, D. B. (1981) “Estimating the Safety Benefits for Alternative Highway and/or Operational Improvements” Report FHWA/RD-81/179, FHWA, Washington, D C. apud CHOUEIRI, Elias M.; LAMM, Ruediger; KLOECKNER, Juergen H.; MAILAENDER, Theodor (1994) “Safety Aspects of Individual Design Elements and Their Interactions on Two-Lane Highways: International Perspective” Transportation Research Record 1445, TRB, pp.34-46

MILLIKEN, R. J.; ZOLLER, C. J. (1978) "Principles of NAVSTAR and System Characteristics” Navigation (USA) 25 (2) In: Janiczek (ed.), vol. I, 3-14, 1980 apud SEEBER, Günter (1993) Satellite Geodesy Foundation Methods, and Application, New York, Editora Walter de Gruyter. 
NATIONAL SAFETY COUNCIL (1985) Accidents Facts - 1985 Edition, Chicago apud U. S. NATIONAL ACADEMY OF SCIENCE TRB (1987) Designing Safer Roads Practices for Resurfacing, Restoration, and Rehabilitation, Special Report 214, Washington, D.C, pp.77-109, TRB.

NEE, R. D. J. van (1992) "Multipath Effects on GPS code phase-measurements" Navigation, 39 (2), pp. 177-190 apud HOFFMANN-WELLENHOF, B.; LICHTENEGGER, H.; Collins, J. (1994). GPS - Theory and Practice, terceira edição, Austria, editora Springer -Verlag Wien.

OECD (1986) Road Safety Research: a Synthesis. Organization for Economic Cooperation and Development, Paris, France. apud LI, Jian; ABDELWAHAB, Walid; BROWN, Gerald (1994) “Join Effects of Access and Geometry on TwoLane Rural Highway Safety in British Columbia” Canadian Journal of Civil Engineering, vol. 21, no. 6, pp.1012-1024, December

OLSEN D. L. (1992) "FRP Update - What to Expect in the 1992 U. S. Federal Radionavigation Plan” SUMMARY RECORD OF THE 20TH MEETING OF THE CIVIL GPS SERVICE INTERFACE COMMITTEE, Albuquerque, New Mexico, September, 14-15 apud HOFFMANN-WELLENHOF, B.; LICHTENEGGER, H.; Collins, J. (1994). GPS - Theory and Practice, terceira edição, Austria, editora Springer -Verlag Wien.

OSTERLOH, H. (1983) "Mathematical Evaluatuion of the Three-Dimensional Impression of the Perspective View for the Driver" Technical Journal: Forschung Strassenbau und Strassenverkehrstechnik (Research Road Construction and Traffic Technique), vol. 394 apud SMITH, Bob L.; LAMM, Ruediger (1994) “Coordination of Horizontal and Vertical Alignment with Regard to Highway Esthetics” Transportation Research Record 1445, pp. 73-85, TRB 
PERREAULT, P. D. (1980) "Description of the Global Positioning system (GPS) and the STI Receivers" CSTG Bulletin vol 2, Technology and Mission Developments apud HOFFMANN-WELLENHOF, B.; LICHTENEGGER, H.; Collins, J. (1994). GPS - Theory and Practice, terceira edição, Austria, editora Springer -Verlag Wien.

REMONDI, B. W. (1984) Using the Global Positioning system (GPS) Phase Observable for Relative Geodesy: Modeling, Processing, and Results, University of Texas at Austin, Center for Space Research apud HOFFMANNWELLENHOF, B.; LICHTENEGGER, H.; Collins, J. (1994). GPS - Theory and Practice, terceira edição, Austria, editora Springer -Verlag Wien.

REMONDI, B. W. (1985) "Performing Centimeters Accuracy Relative Surveys in Seconds Using GPS Carrier Phase” Proc. 1st. Int. Symp. Precise Positioning with GPS, Rockville, vol. 2., pp.789-797 apud SEEBER, G nter (1993) Satellite Geodesy Foundation Methods, and Application, New York, Editora Walter de Gruyter.

REMONDI, B. W. (1988) Extending the National Geodetic Survey Standard GPS Orbit Formats, National Information Center, Rockville, Maryland, NOAA Technical Report NOS 133, NGS 46 apud HOFFMANN-WELLENHOF, B.; LICHTENEGGER, H.; Collins, J. (1994). GPS - Theory and Practice, terceira edição, Austria, editora Springer -Verlag Wien.

REMONDI, B.W. (1985) “Global Positioning System Carrier Phase: Description and Use” Bulletin Géodésique, 59, pp. 361-377 apud HOFFMANNWELLENHOF, B.; LICHTENEGGER, H.; Collins, J. (1994). GPS - Theory and Practice, terceira edição, Austria, editora Springer -Verlag Wien. 
ROTACH, M. C. “Trucks on Gradient” Strasse und Verkehr, vol. 46, pp. 444-446 apud CHOUEIRI, Elias M.; LAMM, Ruediger; KLOECKNER, Juergen H.; MAILAENDER, Theodor (1994) "Safety Aspects of Individual Design Elements and Their Interactions on Two-Lane Highways: International Perspective” Transportation Research Record 1445, TRB, p.34-46

ROY JORGENSEN ASSOCIATES, INC. (1978) "Cost and Safety Effectiveness of Highway Design Elements” NCHRP Report 197, TRB apud LI, Jian; ABDELWAHAB, Walid; BROWN, Gerald (1994) “Join Effects of Access and Geometry on Two-Lane Rural Highway Safety in British Columbia” Canadian Journal of Civil Engineering, vol. 21, no. 6, pp.1012-1024, December.

RUTSCHEIDT, E. H. \& ROTH B. D. (1982) “The NAVSTAR Global Positioning System” CSTG BULLETIN, vol. 4, International Activities Including Proceedings of Symposium 4e, IAG General Meeting Tokyo apud HOFFMANNWELLENHOF, B.; LICHTENEGGER, H.; Collins, J. (1994). GPS - Theory and Practice, terceira edição, Austria, editora Springer -Verlag Wien.

SEEBER, G.; WÜBBENA, G. (1989) "Kinematic Positioning with Carrier Phases and "on the way”Ambiguity Solution” Proc. 5th Int. Geod. Symp. on Satellite Positioning, vol. 2, pp. 606-609, Las Cruzes apud SEEBER, G nter (1993) Satellite Geodesy Foundation Methods, and Application, New York, Editora Walter de Gruyter.

STOVER, V. G.; ADKINS, W. G.; GOODKNIGHT, J. C. (1970) “Guidelines for Medical and Marginal Access Control on Major Roadways” NCHRP Report 93, TRB apud LI, Jian; ABDELWAHAB, Walid; BROWN, Gerald (1994) “Join Effects of Access and Geometry on Two-Lane Rural Highway Safety in British Columbia” Canadian Journal of Civil Engineering, vol. 21, no. 6, pp.1012-1024, December. 
TRANQUILA, J. M. (1986) "Multipath and Imaging Problems in GPS Receiver Antennas" In: PROCEEDINGS OF THE FOURTH INTERNATIONAL GEODETIC SYNPOSIUM ON SATELITE POSITIONING, Austin, Texas, April 28-May 2, vol. 1, pp. 557-571 apud HOFFMANN-WELLENHOF, B.; LICHTENEGGER, H.; Collins, J. (1994). GPS - Theory and Practice, terceira edição, Austria, editora Springer -Verlag Wien.

TRANSPORTATION RESEARCH BOARD (1987) “Designing Safer Roads” Special Report 214, TRB, National Research Council apud TALARICO, R. J.; MORRALL, J. F. (1994) “The cost-effectiveness of curve flattening in Alberta” Canadian Journal of Civil Engineering, vol. 21, no. 2, pp.285-296, April.

WELLS, D. E. (1986) Guide to GPS Positioning, Fredericton apud SEEBER, G nter (1993) Satellite Geodesy Foundation Methods, and Application , New York, Editora Walter de Gruyter.

WÜBBENA, G. (1989) “The GPS Adjustment software Package GEONAP, Concepts and Models” Proc. 5th Int.Geod. Symp. Satellite Positioning, vol. I, pp. 403-412, Las Cruzes apud SEEBER, G nter (1993) Satellite Geodesy Foundation Methods, and Application, New York, Editora Walter de Gruyter.

ZEGEER, C. V.; STEWART, J. R.; COUNCIL, F. M.; REINFURT, D. (1992) "Safety Effects of Geometric Improvements on Horizontal Curves" Transportation Research Record 1356, TRB, p. 11-19 apud TALARICO, R. J.; MORRALL, J. F. (1994) “The cost-effectiveness of curve flattening in Alberta” Canadian Journal of Civil Engineering, vol. 21, no. 2, pp.285-296, April. 
ZEGEER, C. V.; STEWART, J. R.; COUNCIL, F. M.; REINFURT, D. W. (1992) “Safety Effects of Geometric Improvements on Horizontal Curves” 71st Annual Meeting of the Transportation Research Board, Washington, D. C. apud CHOUEIRI, Elias M.; LAMM, Ruediger; KLOECKNER, Juergen H.; MAILAENDER, Theodor (1994) "Safety Aspects of Individual Design Elements and Their Interactions on Two-Lane Highways: International Perspective” Transportation Research Record 1445, TRB, pp.34-46 


\section{BIBLIOGRAFIA CONSULTADA}

ADKINS, Kirk F.; MERRY, Carolyn (1994). “Accuracy Assessment of Elevation Data Sets Using the Global Positioning System” Photogrammetric Engineering \& Remote Sensing, vol. 60, no. 2,pp. 195-202, February.

AL-MASAEID, Hashem R.; HAMED, Mohammad; ABQUI-ELA, Mohammad; GHANNAM, Adnan G. (1995) "Consistency of Horizontal Alignment for Different Vehicle Classes” Transportation Research Record 1500, TRB, pp.178183.

BECKMANN, Angela; LARISCH, Hans-Jurgen; SCHUSTER, Otmar; BARWINSKI, Klaus (1989) “Engineering Applications of GPS Differential Surveying” Journal of Surveying Engineering, vol.115, no.3, pp. 337-346, August.

BERGSTROM, Gary C. (1990) “GPS in Forest Management” GPS World, September/October, p. 46-50

CANNON, M. E. (1992) "Integrated GPS-INS for High-Accuracy Road Positioning” Journal of Surveying Engineering, vol. 118, no. 4, pp. 103-117, November. 
CANNON, M. E.; LACHAPELLE, G. (1993).“Kinematic Ambiguity Resolution with High-Precision C/A Code Receiver” Journal of Surveying Engineering, vol. 119, no. 4, p.147-155, November.

CLEVELAND, Donald E.; KOSTYNIUK, Lidia P.; TING, Kuo-Linag (1984). “Geometric Design Element Group and High-Volume Two-Lane Rural Highway Safety” Transportation Research Record 960, TRB, pp.1-13.

CROMER, Don (1990) “Highway Maintenance Goes High-Tech: The GIS/GPS Link” GPS World, September/October, p. 42-44

ERVIN, Robert D.; MACADAM, Charles C.; BARNES, Michelle (1986) "Influence of the Geometric Design of Highway Ramps on the Stability and Control of Heavy-Duty Trucks” Transportation Research Record 1052, TRB, pp. 77-89.

FARBER, Eugene I. (1987) “Modeling Conflicts at Intersections Hidden by Vertical Curves” Transportation Research Record 1122, TRB, p. 57-67.

FINK, Kenneth L.; KRAMMES, Raymond A. (1995) “Tangent Length and Sight Distance Effects on Accident Rates at Horizontal curves on Rural Two-Lane Highways” Transportation Research Record 1500, TRB, pp.162-168.

FITZPATRICK, Kay (1994) "Horizontal Curve Design : An Exercise in Comfort and Appearance” Transportation Research Record 1445, TRB, p.47-53.

GARBER, Nicholas J.; GADIRAJU, Ravi (1990) "Effects of Truck Strategies on Traffic flow and safety on Multilane Highways” Transportation Research Record 1256, TRB, p.49-55. 
GERICKE, Ogilvie F.; WALTON, C. Michael (1981) “Effect of Increased Truck Size and Weight on Rural Highway Geometric Design (and Redesign) Principles and Practices” Transportation Research Record 806, TRB, pp.13-21.

GLAUZ, William D.; HARWOOD, Douglas W. (1991) “Superelevation and Body Roll Effects on Offtracking of Large Trucks” Transportation Research Record 1303, TRB, p. 1-10.

HARWOOD, Douglas W.; MASON Jr, John M. (1994) “Horizontal Curve Design for Passenger Cars and Trucks” Transportation Research Record 1445, TRB, pp.22-33.

HOMBURGER, Wolfgang (1987) “An Analysis of Safety at Upgrade Terminals of Climbing Lanes on Two-Lane Highways” Transportation Research Record 1122, TRB, p. 27-36.

JACKSON, Lawrence E. (1986) “Truck Accident Studies” Transportation Research Record 1052, TRB, pp.137-145.

JOHN, Andrew D. St.; HARWOOD, Douglas W. (1991) “Safety Considerations for Truck Climbing Lanes on Rural Highways” Transportation Research Record 1303, TRB, p. 74-82.

KRAMMES, Raymond A.; GLASCOCK, Stephen W. (1992) "Geometric Inconsistencies and Accident Experience on Two-Lane Rural Highways” Transportation Research Record 1356, TRB, pp. 1-10.

KRAMMES, Raymond A.; RAO, Kethireddipalli S.; OH, Hoon (1995) “Highway Geometric Design Consistency Evaluation Software” Transportation Research Record 1500, TRB, pp. 19-24. 
LAMM, Ruediger; CHOUEIRI, Elias M. (1987) "Recommendations for Evaluating Horizontal Design Consistency Based on Investigations in State of New York” Transportation Research Record 1122, TRB, p.68-78.

LAMM, Ruediger; GUENTHER, Arthur K.; CHOUEIRI, Elias M. (1995) “Safety Module for Highway Geometric Design” Transportation Research Record 1512, TRB, pp.7-15.

LAMM, Ruediger; SMITH, Bob L. (1994) “Curvilinear Alinement: An Important Issue for More Consistent and Safer Road Characteristic" Transportation Research Record 1445, TRB, p. 12-21.

LOPES, Segundo Carlos (1996) GPS e o Perfil Vertical de Rodovias. São Carlos. Tese de Doutorado - Escola de Engenharia de São Carlos, Universidade de São Paulo

LOUCKES, David K.; McLAUGHLIN, John (1991) "GIS and Tranportation: Canadian Perspective” Journal of Surveying Engineering, vol. 117, $\mathrm{n}^{\circ}$ 3, August, p. 123-133.

LUCAS, James R.; MADER, Gerald L. (1989) “Recent Advances in Kinematic GPS Photogrammetry" Journal of Surveying Engineering, vol.115, no.1, pp. 78-92, February.

MARTIN, David; LONGLEY, Paul; HIGGS, Gary (1994) "The Use of GIS in the Analysis of Diverse Urban Databases” Computation, Environmental and Urban Systems, vol 18. $n^{\circ} 1$, p. 55-66

MCLELLAN, J. F.; KRAKIWSKY, E. J.; SHELEPPE, J. B. (1993) “Application of GPS Positioning to Management of Mobile Operation” Journal of Surveying Engineering, vol. 119, no. 2, p.70-82, May. 
MIAOU, Shaw-Pin; HU, Patricia S.; WRIGHT, Tomy; DAVIS, Stacy C.; RATHI, Ajay K. (1993). “Development of Relationship Between Truck Accidents and Geometric Design: Phase I” FHWA-RD-91-124, March.

MOOYMAN, Ken; QUIRION, Cheryl (1989) "High Production Kinematic GPS Surveying” Surveying and Mapping, vol. 49, no.3, pp. 135-142.

POLUS, Abishai; DAGAN, Doron (1987) “Models for Evaluating the Consistency of Highway Alignment” Transportation Research Record 1122, TRB, p.47-56.

SANTOS, Marcelo Carvalho (1993) “O Sistema de Posicionamento Global GPS e a sua Utilização no Gerenciamento Urbano, Rural e Oceânico” XVI Congresso Brasileiro de Cartografia, vol. I, pp.208-215, outubro.

SCHWARZ, K. P. (1990) "Kinematic Positioning - Efficient New Tool for Surveying” Journal of Surveying Engineering , vol. 116, no. 4, pp. 181-192, November.

WANLESS, Brent (1992) “GPS/Positioned Digital Video for Airborne GIS and Data Acquisition” Journal of Surveying Engineering, vol. 118, no. 3, p. 80-89, August.

WELLS, David, coord. (1987) “Guide to GPS Positioning” Canadian GPS Associates, Canada.

WOOLDRIGE, Mark D. (1994) “Design Consistency and Driver Error” Transportation Research Record 1445, TRB, p. 148-155.

ZEGEER, Charles V.; HUMMER, Joseph; HANSCOM, Fred (1990) “Operational Effects of Larger Trucks on Rural Roadways” Transportation Research Record 1281, TRB, pp. 28-39. 
ZEGGER, Charles V.; DEEN, Robert C.; MAYES, Jesse G. (1981) ."Effect of Lane and Shoulder Widths on Accident Reduction on Rural, Two-Lane Roads” Transportation Research Record 806, TRB, pp.33-43.

ZEGGER, Charles V.; STEWART, Richard; COUNCIL, Forrest; NEUMAN, Timothy (1994) “Accident Relationships of Roadway Width on Low-Volume Roads” Transportation Research Record 1445, p. 160-168. 